Marquette University

e-Publications@Marquette

9-1-2019

\title{
The Parmodulin NRD-21 is an Allosteric Inhibitor of PAR1 Gq Signaling with Improved Anti-Inflammatory Activity and Stability
}

\author{
Disha M. Gandhi \\ Marquette University \\ Ricardo Rosas Jr. \\ Marquette University \\ Eric Greve \\ Marquette University \\ Kaitlin Kentala \\ Marquette University \\ N'Guessan D.-R, Diby \\ Marquette University
}

See next page for additional authors

Follow this and additional works at: https://epublications.marquette.edu/chem_fac

Part of the Chemistry Commons

\section{Recommended Citation}

Gandhi, Disha M.; Rosas, Ricardo Jr.; Greve, Eric; Kentala, Kaitlin; Diby, N'Guessan D.-R;; Snyder, Vladyslava A.; Stephans, Allison; Yeung, Teresa H.W.; Subramaniam, Saravanan; DiMilo, Elliot; Kurtenbach, Khia E.; Arnold, Leggy A.; Weiler, Hartmut; and Dockendorff, Chris, "The Parmodulin NRD-21 is an Allosteric Inhibitor of PAR1 Gq Signaling with Improved Anti-Inflammatory Activity and Stability" (2019). Chemistry Faculty Research and Publications. 970.

https://epublications.marquette.edu/chem_fac/970 


\section{Authors}

Disha M. Gandhi; Ricardo Rosas Jr.; Eric Greve; Kaitlin Kentala; N'Guessan D.-R, Diby; Vladyslava A. Snyder; Allison Stephans; Teresa H.W. Yeung; Saravanan Subramaniam; Elliot DiMilo; Khia E. Kurtenbach; Leggy A. Arnold; Hartmut Weiler; and Chris Dockendorff 
Marquette University

\section{e-Publications@Marquette}

\section{Chemistry Faculty Research and Publications/College of Arts and Sciences}

This paper is NOT THE PUBLISHED VERSION; but the author's final, peer-reviewed manuscript. The published version may be accessed by following the link in th citation below.

Biorganic \& Medicinal Chemistry, Vol. 27, No. 17 (September 2019): 3788-3796. DOI. This article is (C) Elsevier and permission has been granted for this version to appear in e-Publications@Marquette. Elsevier does not grant permission for this article to be further copied/distributed or hosted elsewhere without the express permission from Elsevier.

\section{The parmodulin NRD-21 is an allosteric inhibitor of PAR1 Gq signaling with improved anti-inflammatory activity and stability}

Disha M. Gandhi ${ }^{1}$

Department of Chemistry, Marquette University, P.O. Box 1881, Milwaukee, WI 53201-1881, USA

Ricardo Rosas Jr. ${ }^{1}$

Department of Chemistry, Marquette University, P.O. Box 1881, Milwaukee, WI 53201-1881, USA

Eric Greve

Department of Chemistry, Marquette University, P.O. Box 1881, Milwaukee, WI 53201-1881, USA

Kaitlin Kentala

Department of Chemistry, Marquette University, P.O. Box 1881, Milwaukee, WI 53201-1881, USA

N'Guessan D.-R. Diby

Department of Chemistry, Marquette University, P.O. Box 1881, Milwaukee, WI 53201-1881, USA

Vladyslava A. Snyder 
Department of Chemistry, Marquette University, P.O. Box 1881, Milwaukee, WI 53201-1881, USA

\author{
Allison Stephans \\ Department of Chemistry, Marquette University, P.O. Box 1881, Milwaukee, WI 53201-1881, USA
}

Teresa H. W. Yeung

Department of Chemistry, Marquette University, P.O. Box 1881, Milwaukee, WI 53201-1881, USA

Saravanan Subramaniam

Blood Research Institute, Versiti, Milwaukee, WI 53226, USA

\title{
Elliot DiMilo
}

Department of Chemistry and Biochemistry, Milwaukee Institute for Drug Discovery, University of Wisconsin, Milwaukee, WI 53211, USA

\section{Khia E. Kurtenbach}

Department of Chemistry, Marquette University, P.O. Box 1881, Milwaukee, WI 53201-1881, USA

\section{Leggy A. Arnold}

Department of Chemistry and Biochemistry, Milwaukee Institute for Drug Discovery, University of Wisconsin, Milwaukee, WI 53211, USA

\section{Hartmut Weiler}

Blood Research Institute, Versiti, Milwaukee, WI 53226, USA

Department of Physiology, Medical College of Wisconsin, Milwaukee, WI 53226, USA

\section{Chris Dockendorff}

Department of Chemistry, Marquette University, P.O. Box 1881, Milwaukee, WI 53201-1881, USA

\section{Abstract}

Novel analogs of the allosteric, biased PAR1 ligand ML161 (parmodulin 2, PM2) were prepared in order to identify potential anti-thrombotic and anti-inflammatory compounds of the parmodulin class with improved properties. Investigations of structure-activity relationships of the western portion of the 1,3-diaminobenzene scaffold were performed using an intracellular calcium mobilization assay with endothelial cells, and several heterocycles were identified that inhibited PAR1 at sub-micromolar concentrations. The oxazole NRD-21 was profiled in additional detail, and it was confirmed to act as a selective, reversible, negative allosteric modulator of PAR1. In addition to inhibiting human platelet aggregation, it showed superior anti-inflammatory activity to ML161 in a qPCR assay measuring the expression of tissue factor in response to the cytokine TNF-alpha in endothelial cells. Additionally, NRD-21 is much more plasma stable than ML161, and is a promising lead compound for the parmodulin class for anti-thrombotic and anti-inflammatory indications. 


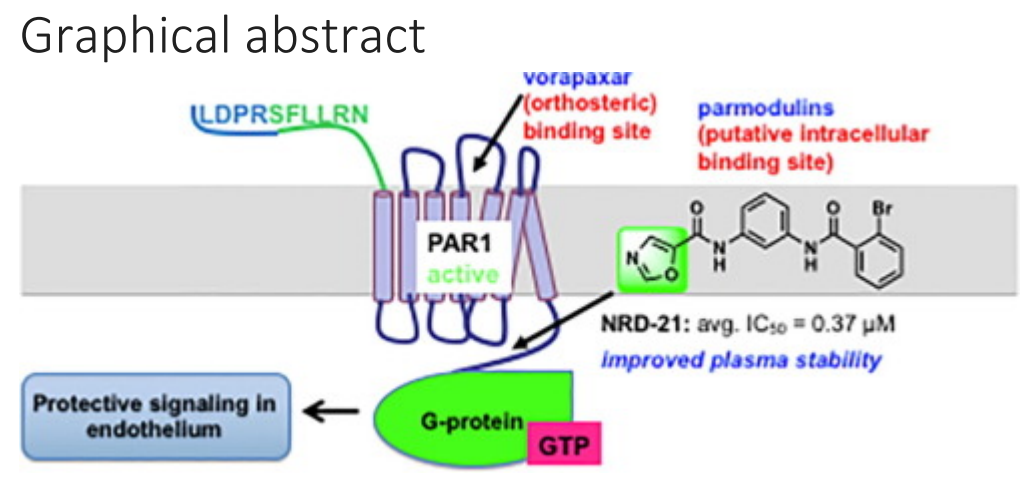

\section{Abbreviations}

aPC: activated Protein C; Boc: tert-butoxycarbonyl; DCE: 1,2-dichloroethane; DCM: dichloromethane; DIC: disseminated intravascular coagulation; DIPEA: $N, N$-diisopropylethylamine; DMAP: 4-dimethylaminopyridine; DMF: $N, N$-dimethylformamide; DMSO: dimethylsulfoxide; EDC: 1-ethyl-3-(3-dimethylaminopropyl)carbodiimide; FDA: U.S. Food and Drug Administration; GPCR: G protein coupled receptor; HATU: hexafluorophosphate azabenzotriazole tetramethyl uranium; HOBt: 1-hydroxybenzotriazole; HTS: high-throughput screening; HUVEC: human umbilical vein endothelial cells; $\mathrm{IC}_{50}$ : half-maximal inhibitory concentration; $\mathrm{iCa}^{2+}$ : intracellular calcium mobilization; LC-MS: liquid chromatography-mass spectrometry; MI: myocardial infarction; NMR: nuclear magnetic resonance; PAR: protease-activated receptor; qPCR: quantitative polymerase chain reaction; SAR: structure-activity relationship; SEM: standard error of the mean; TF: tissue factor; TLC: thin layer chromatography; TNF- $\alpha$ : Tumor Necrosis Factor-alpha

\section{Keywords}

Parmodulin, NRD-21, ML161, PAR1, Allosteric inhibitor, Oxazole, Anti-platelet, Antithrombotic, Antiinflammatory, Biased ligand

\section{Introduction}

The use of biased ligands for $\mathrm{G}$ protein coupled receptors (GPCRs) has emerged as a promising strategy for maximizing therapeutic signals mediated by GPCRs, while potentially mitigating undesired side effects linked to alternative signaling pathways initiated by the same receptors. Protease-activated receptors (PARs) are GPCRs that are activated by a variety of vascular proteases that cleave the $\mathrm{N}$-termini of PARs, revealing a tethered peptide that activates the receptor ${ }^{1}$ and initiates a plethora of signals. ${ }^{2}$ PARs are present in a variety of tissues and are implicated in a variety of pathologies including thrombosis, inflammation, and cancer cell metastasis. $\underline{3}, \underline{4}$ The varied phenotypic effects of PAR activation have recently been connected to the activation of specific Gproteins and arrestins, $\frac{5}{}$ and biased signals have been observed with proteases such as activated protein $\mathrm{C}$ (aPC) that cleave PAR $N$-termini at alternative sites. $\underline{6}, \underline{7} \underline{8}, \underline{9}, \underline{10}$ Synthetic peptides $\underline{11}, \underline{12}$ and peptidomimetics $\underline{13}, \underline{14}$ based on PAR tethered ligands have also shown biased signaling by blocking or activating only a subset of signals. Pepducins, a novel class of fatty acid-tethered peptides modeled after intracellular GPCR loops developed by Kuliopulos and coworkers, $\underline{15}, \underline{16}, \underline{17}$ have been reported to act as biased antagonists at PAR2.4 $\underline{18}$ Previously, we reported that small molecules identified via high-throughput screening (HTS) are capable of inhibiting platelet granule secretion, while permitting the shape change of platelets normally observed upon platelet activation via PAR1 agonism, thus acting as "biased antagonists" of PAR1.19, $\underline{20}$ Our collaborators (Flaumenhaft and coworkers) have accrued evidence that these small molecules, termed parmodulins, act at the intracellular side of PAR1 to block signaling mediated by Gq, but not G12/13.21, 22 The parmodulin ML161 (1, also referred to as parmodulin 2 or PM2, Figure 1) was found to promote cytoprotective and anti-inflammatory effects in endothelium in a manner similar to $\mathrm{APC}, \underline{\underline{22}}$ and as with aPC it was highly effective at minimizing necrosis of coronary tissue in a mouse model of myocardial infarction (MI). $\underline{23}$ We also recently confirmed that ML161 and its aniline analog RR-90 are selective, reversible, and allosteric inhibitors (negative allosteric 
modulators) of PAR1 signaling via the $\mathrm{G}$ protein $\mathrm{Gq} .{ }^{24}$ The presence of PAR1 is required for the cytoprotective effects of aPC $\underline{25}$ and ML1611ㅡ, $\underline{22}$ in endothelium, and targeting PAR1 with parmodulins to inhibit pro-

inflammatory or pro-thrombotic signals while activating beneficial anti-inflammatory and/or cytoprotective signals could be an effective therapeutic strategy for sepsis, stroke, and thrombosis. This manuscript describes our efforts to more deeply explore structure-activity relationships (SARs) at the western side of parmodulins possessing the 1,3-diaminobenzene scaffold, exemplified by ML161.

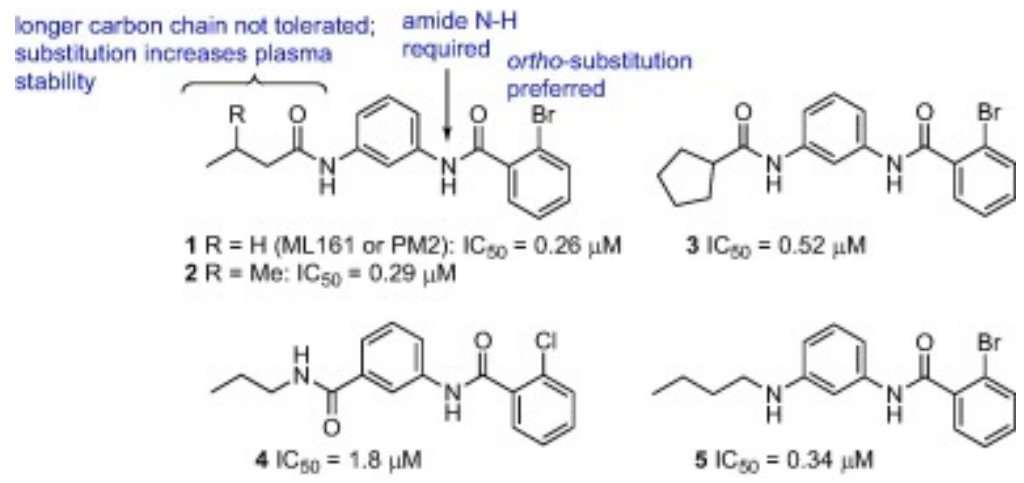

Figure 1. Previous parmodulins and their performance in a platelet P-selectin assay. $\underline{20}$

ML161 was previously assigned as a Molecular Libraries probe, $\underline{20}, \underline{26}$ and was our most potent analog to date in the P-selectin assay, a flow cytometry assay which measures levels of P-selectin on the surface of activated platelets. Our interest in measuring the effects of parmodulins in endothelial cells led us to develop a protocol for an intramolecular calcium mobilization $\left(i \mathrm{Ca}^{2+}\right)$ assay using adherent EA.hy 926 cells in 96 well plates..$^{24}$ Both responses are driven by PAR1 Gq, but the endothelial calcium assay also offers higher throughput and lower variability than the platelet P-selectin assay, so we have utilized it as our primary assay for ongoing studies. Compounds were screened in 96 well plates at a concentration of $10 \mu \mathrm{M}$, using the PAR1 tethered ligand peptide TFLLRN-NH $2(5 \mu \mathrm{M})$ as agonist. 7-point concentration-response curves were obtained for compounds demonstrating $>70 \%$ inhibition in this screen, which was an arbitrary cutoff.

A significant liability of ML161 is its low stability in mouse plasma. The branched amide 2 was equipotent to ML161 in the platelet P-selectin assay, but showed greatly improved stability in mouse plasma after $5 \mathrm{~h}(65 \%$ remaining vs $2 \%$ ), presumably due to increased resistance to protease-catalyzed hydrolysis. $\underline{20}$ Unfortunately, 2 possesses decreased solubility in water with $1 \%$ DMSO $(9 \mu \mathrm{M}$ vs $58 \mu \mathrm{M}$ for 1$), \underline{\underline{20}}$ and mediocre inhibition in the endothelial $i \mathrm{Ca}^{2+}$ assay (Table 1). ${ }^{\underline{24}}$ Therefore, we focused our efforts on finding alternative analogs that could offer equal or better potency than ML161 in the $i \mathrm{Ca}^{2+}$ assay but with improved plasma stability, which is particularly important for longer duration in vivo experiments.

Table 1. SAR of simple alkyl analogs.

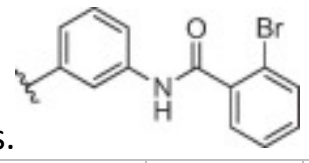

\begin{tabular}{|c|c|c|c|c|c|}
\hline Cmpd; & Structure & $\mathrm{iCa}^{2+}$ assay \%Inhib; & Cmpd; & Structure & $\mathrm{iCa}^{2+}$ assay \%Inhib; \\
\hline ID\# & & $\mathrm{plC}_{50}^{\mathrm{a}}$ & ID\# & & $\mathrm{plC}_{50}^{\mathrm{a}}$ \\
\hline 1 & & $82 \pm 2 \%$ & 8 & & $54 \pm 3 \%$ \\
\hline ML161 & & $6.1 \pm 0.1$ & & & $5.5 \pm 0.3$ \\
\hline 2 & & $82 \pm 2 \%$ & 9 & & $88 \pm 1 \%$ \\
\hline CJD-125 & & undef. $^{b}$ & NRD-25 & & $6.4 \pm 0.2$ \\
\hline
\end{tabular}




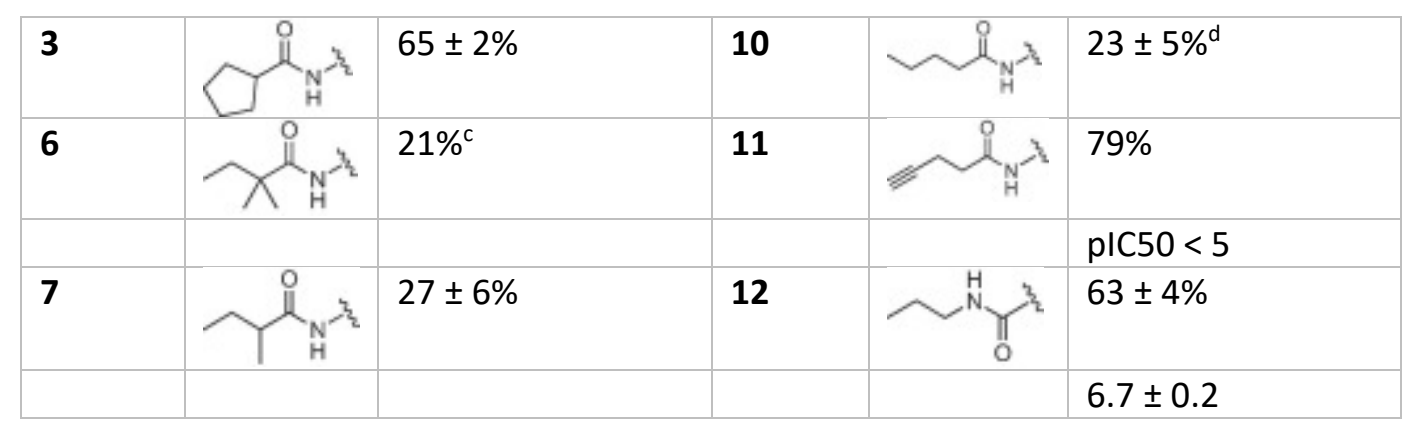

a. Assays were performed with adherent EA.hy926 endothelial cells according to the protocol reported in the Supporting Info. \% Inhibition was measured at $10 \mu \mathrm{M}$ with $5 \mu \mathrm{M}$ TFLLRN-NH $\mathrm{N}_{2}$ and $\mathrm{n}=4$ wells, unless otherwise noted, with standard error of the mean (SEM) provided. $\mathrm{pIC}_{50} \mathrm{~S}\left(-\log \mathrm{C}_{50} \mathrm{~S}\right)$ were estimated from curves fitted to measurements on 3 separate wells for each concentration, using 4-variable non-linear regression in GraphPad Prism v. 6. The detailed assay protocol was previously described. .4

b. $\quad I_{50}$ is undefined-a double sigmoidal concentration-response curve was not obtained.

c. In platelet P-selectin assay. $\underline{\underline{20}}$

d. $n=3$.

\section{Results}

This manuscript describes our SAR studies with modifications to the "western" end of the scaffold. Many of these analogs, including the most promising analogs identified herein, could be prepared via simple acylation reactions of aniline precursors (Scheme 1 ). The eastern 2-bromobenzamide of ML161 that was optimized previously was fixed at this stage, though other eastern benzene substitutions are also tolerated.

Scheme 1. General conditions for the synthesis of western amide analogs.

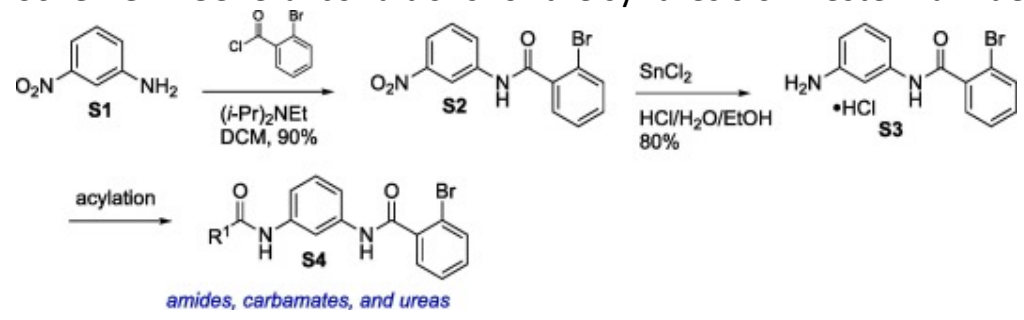

Following up on our previous modifications at the western side exemplified by $\mathbf{1}$ and $\mathbf{2}$, we explored the role of branching and chain length (Table 1). The cyclopentyl analog 3 showed moderate inhibition, but increasing further the level of substitution at the alpha position (6) greatly increased plasma stability but decreased inhibition greatly in the platelet P-selectin assay. $\frac{20}{-}$ The acyclic analog 7 also showed weak efficacy in the $i \mathrm{Ca}^{2+}$ assay. Compound 8, with one carbon less than ML161, also showed decreased activity, but interestingly its more lipophilic trifluoromethyl analog 9 showed increased potency $\left(\mathrm{IC}_{50}=0.38 \mu \mathrm{M}\right)$ compared to 8 and similar activity to ML161. Alternatively, extension of the carbon chain of ML161 by one led to decreased efficacy and/or potency (compounds $\mathbf{1 0}$ and $\mathbf{1 1}$ ), which is consistent with what we observed previously with platelets. $\underline{\underline{20}} \mathrm{~A}$ close analog of the previously-reported reverse amide 4 (Figure 1) was also prepared (12), and showed very good potency $\left(I C_{50}=0.22 \mu \mathrm{M}\right)$, but only moderate efficacy ( 50\% maximal inhibition). Such reverse amides could address potential liabilities associated with toxic anilide or aniline hydrolysis products.

Introduction of polar functional groups was performed in order to improve the potency and drug-like properties of 1 and $\mathbf{2}$ (Table 2). Addition of hydroxy or methoxy groups (compounds 13-18) led to significant losses of efficacy. Malonate derivatives (19-21) also showed weak efficacy. Two carbamates were synthesized (22 and 23), with 23 showing moderate activity (60\% inhibition at $10 \mu \mathrm{M})$, as did ether 24 . 
Table 2. SAR of neutral or acidic analogs.

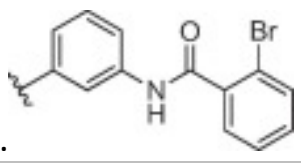

\begin{tabular}{|c|c|c|c|c|c|}
\hline $\begin{array}{l}\text { Cmpd; } \\
\text { ID\# }\end{array}$ & Structure & $\begin{array}{l}i \mathrm{Ca}^{2+} \text { assay \%Inhib; } \\
\mathrm{plC}_{50^{2}}{ }^{\mathrm{a}}\end{array}$ & $\begin{array}{l}\text { Cmpd; } \\
\text { ID\# }\end{array}$ & Structure & $\begin{array}{l}i \mathrm{iCa}^{2+} \text { assay \%Inhib; } \\
\mathrm{plC}_{50^{2}}\end{array}$ \\
\hline 13 & & $39 \pm 5 \%$ & 19 & & $11 \pm 12 \%$ \\
\hline 14 & & $21 \pm 2 \%$ & 20 & & $37 \pm 11 \%$ \\
\hline 15 & & $25 \pm 5 \%$ & 21 & & $36 \pm 13 \%$ \\
\hline 16 & & $48 \pm 13 \%$ & 22 & & $42 \pm 12 \%$ \\
\hline 17 & & $38 \pm 5 \%$ & 23 & & $60 \pm 4 \%$ \\
\hline 18 & & $58 \pm 7 \%$ & 24 & $\widehat{\widehat{O}} 0^{-\frac{3}{2}}$ & $57 \pm 4 \%$ \\
\hline
\end{tabular}

a. Assays were performed with adherent EA.hy926 endothelial cells according to the protocol reported in the Supporting Info. \% Inhibition was measured at $10 \mu \mathrm{M}$ with $5 \mu \mathrm{M}$ TFLLRN-NH $\mathrm{H}_{2}$ and $\mathrm{n}=4$ wells, unless otherwise noted, with standard error of the mean (SEM) provided. $\mathrm{plC}_{50}\left(-\log \mid \mathrm{C}_{50} \mathrm{~S}\right)$ were estimated from curves fitted to measurements on 3 separate wells for each concentration, using 4-variable non-linear regression in GraphPad Prism v. 6. The detailed assay protocol was previously described. $\underline{24}$

Continuing with more basic amine functionality (Table 3), we found that incorporation of a dimethylamine unit at the western end (25) led to a complete loss of activity. However, as previously reported, $20, \underline{24}$ the aniline RR90 (5) showed very good activity and similar potency to ML161. The tertiary aniline $\mathbf{2 6}$ showed weak activity, as did the aniline $\mathbf{2 7}$ with a terminal ether. Preparation of the more basic analog $\mathbf{2 8}$ also led to a steep drop in efficacy. Interestingly, the anilines $\mathbf{2 9}$ and $\mathbf{3 0}$ both showed evidence of activation, rather than inhibition, of PAR1. Aniline $\mathbf{2 9}$ was synthesized via a reductive amination reaction with the aniline precursor $\mathbf{S 3}$ (Scheme 1) and cyclopentenone, and $\mathbf{3 0}$ was prepared by cyclization of the same precursor with 1,4-dibromobutane (see Supplementary data for details). Aniline $\mathbf{3 0}$ (KMK-17) is presently under investigation as a potential positive allosteric modulator of PAR1.

Table 3. SAR of amine analogs.<smiles>Cc1cccc(NC(=O)c2ccccc2Br)c1</smiles>

\begin{tabular}{|c|c|c|c|c|c|}
\hline Cmpd; & Structure & $\mathrm{iCa}^{2+}$ assay \%Inhib; & Cmpd; & Structure & $i \mathrm{Ca}^{2+}$ assay \%Inhib; \\
\hline ID\# & & $\mathrm{plC}_{50^{-}}$ & ID\# & & $\mathrm{plC}_{50^{-}}$ \\
\hline 25 & & $3 \pm 3 \%$ & 28 & & $17 \pm 6 \%$ \\
\hline \multicolumn{6}{|l|}{ VAK-11 } \\
\hline 5 & & $85 \pm 2 \%$ & 29 & & $-12 \pm 6 \%$ \\
\hline RR-90 & & $6.0 \pm 0.2$ & & & \\
\hline \multirow[t]{2}{*}{26} & & $13 \pm 2 \%$ & 30 & & $-60 \pm 8 \%$ \\
\hline & & & KMK-17 & & \\
\hline
\end{tabular}


a. Assays were performed with adherent EA.hy926 endothelial cells according to the protocol reported in the Supporting Info. \% Inhibition was measured at $10 \mu \mathrm{M}$ with $5 \mu \mathrm{M}$ TFLLRN-NH $\mathrm{N}_{2}$ and $\mathrm{n}=4$ wells, unless otherwise noted, with standard error of the mean (SEM) provided. $\mathrm{pIC}_{50} \mathrm{~S}\left(-\log \mid \mathrm{C}_{50} \mathrm{~S}\right)$ were estimated from curves fitted to measurements on 3 separate wells for each concentration, using 4-variable non-linear regression in GraphPad Prism v. 6. The detailed assay protocol was previously described. $.^{24} n=3$.

Next, we explored heterocyclic amide analogs (Table 4). The exploration of western pyrrolidine derivatives (3134) initially yielded differences in activity between the $R$ - and $S$-enantiomers in both the Boc-protected pyrrolidines $(\mathbf{3 1}, \mathbf{3 3})$ and the deprotected derivatives $(\mathbf{3 2}, \mathbf{3 4})$. However, re-synthesis and retesting of 31-34 to obtain concentration-response curves did not show significant inhibition of calcium mobilization by the PAR1 agonist TFLLRN-NH${ }_{2}$.

Table 4. SAR of heterocyclic amide analogs.

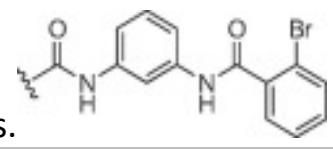

\begin{tabular}{|c|c|c|c|c|c|}
\hline Cmpd; & Structure & $i \mathrm{Ca}^{2+}$ assay \%Inhib; & Cmpd; & Structure & $i \mathrm{Ca}^{2+}$ assay \%Inhib; \\
\hline ID\# & & $\mathrm{plC}_{50^{-}}^{\mathrm{a}}$ & ID\# & & $\mathrm{plC}_{50^{-}}^{\mathrm{a}}$ \\
\hline 31 & & $65 \pm 4 \%^{b}$ & 36 & & $42 \pm 3 \%$ \\
\hline 32 & & $63 \pm 4 \%^{b}$ & 37 & & $44 \pm 2 \%$ \\
\hline \multirow[t]{2}{*}{33} & & $-8 \pm 6 \%^{b}$ & 38 & & $90 \pm 1 \%$ \\
\hline & & & NRD-21 & & $6.3 \pm 0.1$ \\
\hline \multirow[t]{2}{*}{34} & & $4 \pm 6 \%^{b}$ & 39 & & $82 \pm 1 \%$ \\
\hline & & & NRD-23 & & $6.4 \pm 0.1$ \\
\hline 35 & & $92 \pm 1 \%$ & 40 & & $58 \pm 4 \%$ \\
\hline
\end{tabular}

a. Assays were performed with adherent EA.hy926 endothelial cells according to the protocol reported in the Supporting Info. \% Inhibition was measured at $10 \mu \mathrm{M}$ with $5 \mu \mathrm{M}$ TFLLRN- $\mathrm{NH}_{2}$ and $\mathrm{n}=4$ wells, unless otherwise noted, with standard error of the mean (SEM) provided. $\mathrm{pIC}_{50} \mathrm{~S}\left(-\log \mathrm{C}_{50 \mathrm{~S}}\right)$ were estimated from curves fitted to measurements on 3 separate wells for each concentration, using 4-variable non-linear regression in GraphPad Prism v. 6. The detailed assay protocol was previously described. ${ }^{24}{ }^{b}$ These compounds were resynthesized and retested and were found to be inactive when 7-point concentrationresponse curves were obtained.

The furan 35 showed a high level of inhibition $\left(92 \%, \mathrm{IC}_{50}=0.32 \mu \mathrm{M}\right)$, which prompted us to explore other oxygen-containing heterocycles, particularly since monosubstituted furans such $\mathbf{3 5}$ may suffer from undesirable oxidative metabolism. The tetrahydrofurans $\mathbf{3 6}$ and $\mathbf{3 7}$ showed only modest inhibition, but the oxazoles $\mathbf{3 8}$ and $\mathbf{3 9}$ showed very good inhibition. The phenyl analog $\mathbf{4 0}$ can be considered as a control compound, and it displayed moderate inhibition (58\%).

The potent oxazoles 38 (NRD-21) and 39 (NRD-23) were profiled further, along with the trifluoromethyl analog 9 (NRD-25) and the furan 35 (VAK-7) (Figure 2). Concentration-response curves were obtained in our intracellular calcium mobilization assay. All four analogs showed similar potencies $\left(\mathrm{IC}_{50}=0.32\right.$ to $\left.0.42 \mu \mathrm{M}\right)$, though 
interestingly the oxazole 38 showed much better efficacy than $\mathbf{3 9}$, which only inhibited calcium activity at $\sim 50 \%$ at the highest concentration $(31.6 \mu \mathrm{M})$.
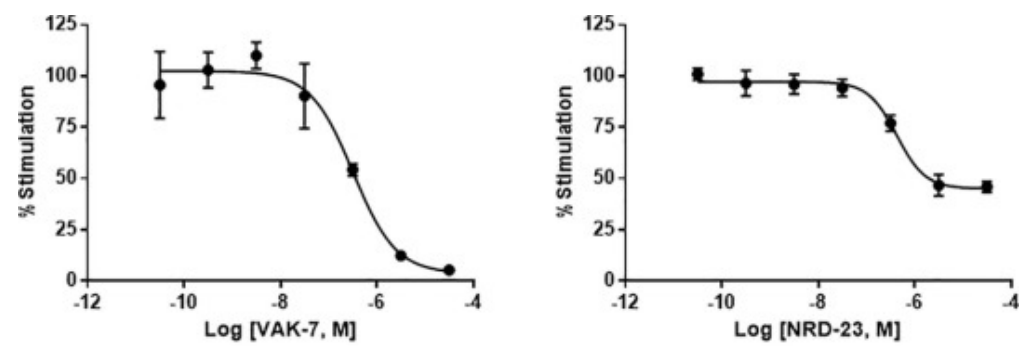

$\mathrm{IC}_{50}=0.32 \mu \mathrm{M}$
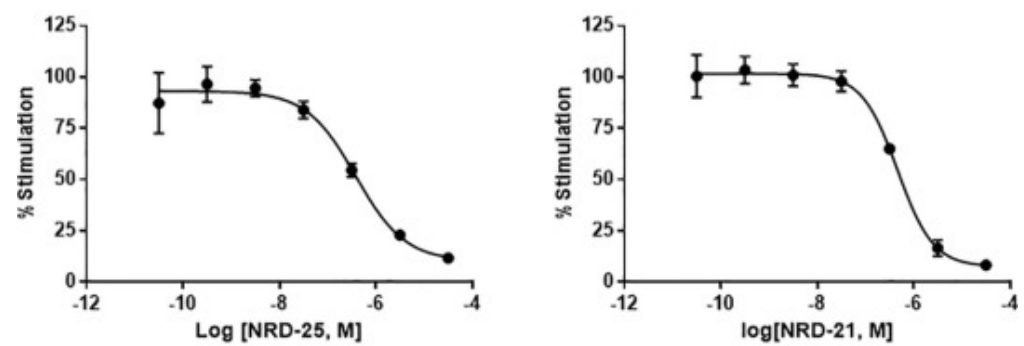

$\mathrm{IC}_{50}=0.38 \mu \mathrm{M}$

Average $\mathrm{IC}_{50}=0.38 \mu \mathrm{M}$

Figure 2. Concentration-response curves for PAR1 antagonists in the TFLLRN- $\mathrm{NH}_{2}$-mediated $(5 \mu \mathrm{M}) \mathrm{iCa}{ }^{2+}$ mobilization assay with EA.hy926 cells: A) 35 (VAK-7), B) 39 (NRD-23), C) 9 (NRD-25), D) 38 (NRD-21).

Our previous studies showed the lead compound ML161 (1) and aniline 5 to have selective and reversible activity towards PAR1. We endeavored to determine if our novel analogs possess the same properties.

Selectivity for PAR1 was conducted with our calcium mobilization assay and PAR1 or PAR2 agonists (Figure 3). EA.hy926 cells were dosed with either vorapaxar at $0.316 \mu \mathrm{M}$ or the selected parmodulin at $10 \mu \mathrm{M}$. The cells were then stimulated using either the PAR1 agonist TFLLRN-NH $\mathrm{N}_{2}$ or the PAR2 agonist SLIGKV-NH 2 at 3.16 $\mu \mathrm{M}$. All parmodulins and vorapaxar showed inhibition of the PAR1 receptor (Figure $3 A$ ). Consistent with Table 4, oxazole 39 (NRD-23) was the only parmodulin that showed $<75 \%$ inhibition of PAR1, while all other parmodulins and vorapaxar exhibited $>75 \%$ inhibition ( $<25 \%$ stimulation) (Figure $3 \mathrm{~A}$ ). All antagonists tested with the PAR2 agonist SLIGKV-NH 2 showed no inhibition of PAR2 (igure 3B), therefore we conclude that all analogs are highly selective for PAR1 over PAR2.
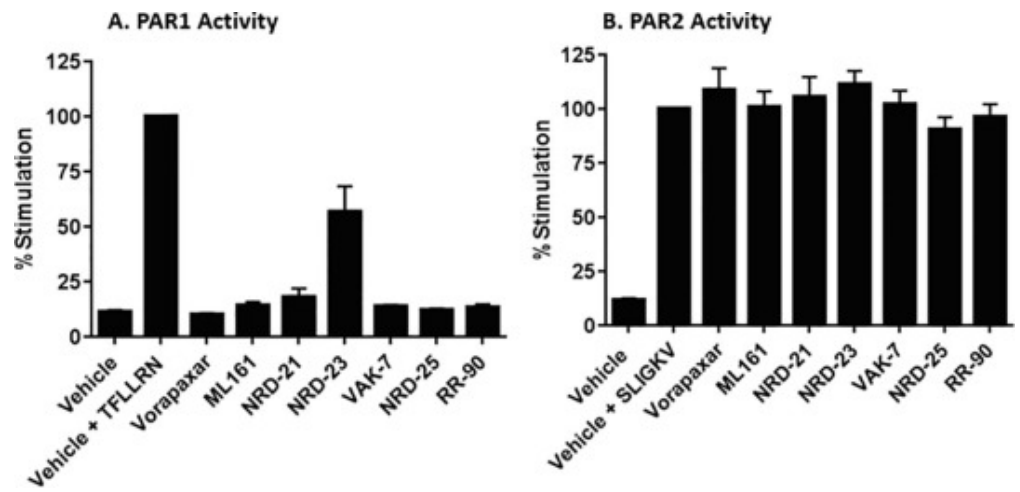

Figure 3. Selectivity data of antagonists in A) PAR1 (TFLLRN-NH ${ }_{2}$ )- and B) PAR2 (SLIGKV-NH ) $^{\text {-driven }}$ iCa ${ }^{2+}$ mobilization. Parmodulins were used at $10 \mu \mathrm{M}$; vorapaxar was used at $0.316 \mu \mathrm{M}$. PAR1 agonist TFLLRN-NH $\mathrm{H}_{2}$ and PAR2 agonist SLIGKV-NH 2 were used at $3.16 \mu \mathrm{M}$; Vehicle $(\mathrm{V})=10 \%$ DMSO/water.

We also conducted "wash" studies where the endothelial cells were treated with select inhibitors, then washed twice with buffer prior to addition of the agonist and measurement of intracellular calcium levels (Figure 4). 
Parmodulins were compared to vorapaxar, which is a known poorly reversible orthosteric inhibitor of PAR1. As expected, all parmodulins tested had a significant loss of inhibition after washing, while vorapaxar remained unaffected, confirming that they inhibit PAR1 in a reversible manner.

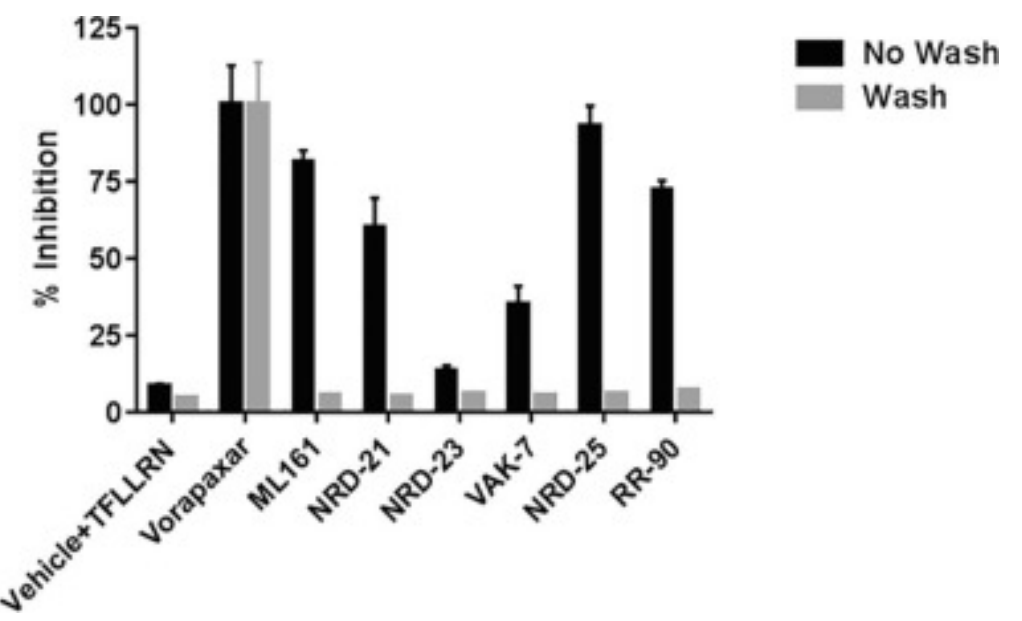

Figure 4. Reversibility studies of the PAR1 antagonist vorapaxar and selected parmodulins. Parmodulins were used at $10 \mu \mathrm{M}$; vorapaxar was used at $0.316 \mu \mathrm{M}$. PAR1 agonist TFLLRN-NH 2 and PAR2 agonist SLIGKV-NH $\mathrm{N}_{2}$ were used at $3.16 \mu \mathrm{M}$; Vehicle $(\mathrm{V})=10 \% \mathrm{DMSO} /$ water. Cells containing antagonist were washed with buffer prior to the treatment with PAR1 agonist TFLLRN-NH $2(5 \mu \mathrm{M})$.

Out of the four parmodulins profiled, compound 38 (NRD-21) was selected for further studies; we reasoned that the trifluoromethyl analog 9 , though potent, likely possesses the same plasma stability and solubility liabilities as ML161. ML161 was characterized as a negative allosteric modulator in both platelets and endothelial cells in our previous studies, and we reasoned that the structurally similar NRD-21 would act in a similar manner. Indeed, increasing concentrations of antagonist 38 led to a reduction in efficacy of the PAR1 agonist TFLLRN-NH (Figure $^{-}$ 5). The reduction of maximum efficacy ("ceiling effect") of the PAR1 agonist in the presence of NRD-21, rather than the simple rightward shift in concentration-response curves, is consistent with the action of NRD-21 as a negative allosteric modulator of TFLLRN-NH $\mathrm{N}_{2}$ at PAR1, rather than a simple competitive inhibition. We previously reported this phenomenon with ML161.20, 24 Interestingly the drop in maximal efficacy is not as pronounced for NRD-21 as for the aniline $\mathbf{5}$ (RR-90), which we previously described. $\underline{\underline{24}}$

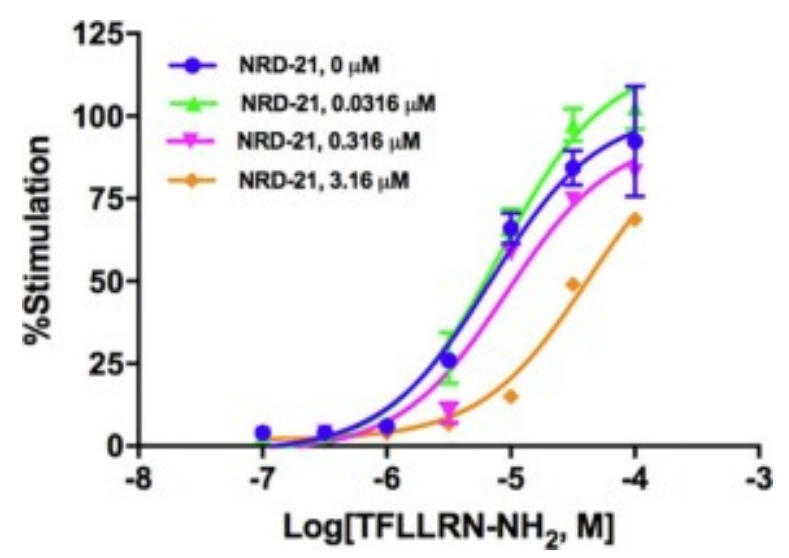

Figure 5. $\mathrm{iCa}^{2+}$ concentration-response of the PAR1 agonist TFLLRN-NH ${ }_{2}$ in the presence of increasing concentrations of NRD-21.

Next, an assay was performed to measure the ability of NRD-21 to inhibit platelet aggregation. PAR1 is highly expressed in platelets, and its activation leads to aggregation and coagulation. The platelet aggregation assay was performed with ML161 and NRD-21 (igure 6). In both cases, human washed platelets were incubated with 
parmodulins at $10 \mu \mathrm{M}$, then the PAR1/2 agonist SFLLRN-NH $2(1.5 \mu \mathrm{M})$ was added. Complete inhibition of platelet aggregation by both ML161 and NRD-21 was observed.
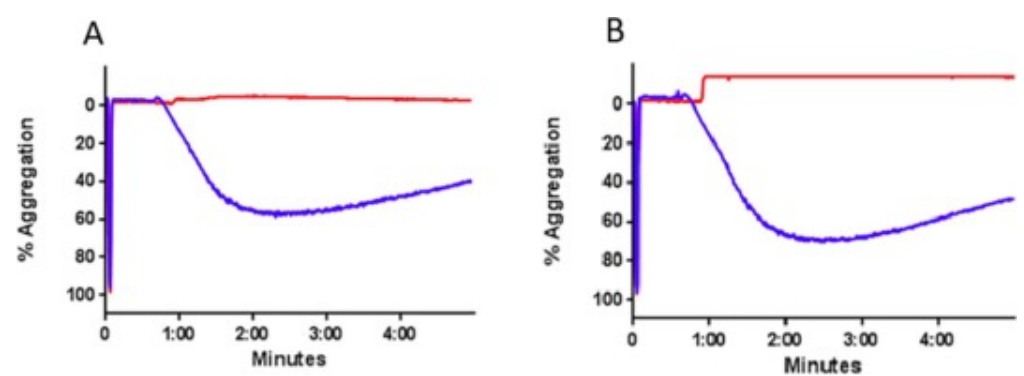

Figure 6. Human platelet aggregation assay of $A) \mathrm{ML161}(10 \mu \mathrm{M}$, red trace) and $\mathrm{B}) \mathrm{NRD}-21(10 \mu \mathrm{M}$, red trace) in the presence of the PAR1/2 agonist SFLLRN-NH $2(1.5 \mu \mathrm{M})$. Blue traces = DMSO.

The anti-inflammatory and cytoprotective effects reported for ML161ㄴ1, 22, 23 begged the question if other structurally related parmodulins also share these effects. To this end, we performed a qPCR assay measuring the expression of tissue factor (TF) in endothelial cells (HUVEC) in response to the inflammatory cytokine Tumor Necrosis Factor-alpha (TNF- $\alpha$ ). TF has been long established to mediate the pro-inflammatory and pro-coagulant effects $\underline{27}$ of TNF- $\alpha \underline{28}, \underline{29}$ and endotoxins, $\underline{\underline{30}}$ and unnatural TF expression is therefore the driver of disseminated

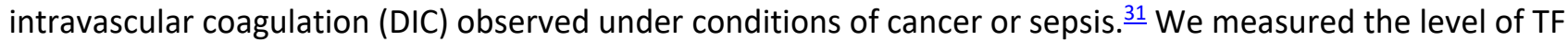
mRNA $4 \mathrm{~h}$ after treatment with ML161 or NRD-21 followed by the addition of TNF- $\alpha$ (Figure 7). Pretreatment with ML161 (column 4) blocked the 3-fold increase in TF expression caused by TNF- $\alpha$ alone (column 1), and NRD-21 was even more efficacious, dropping TF RNA levels to below baseline levels. The mechanism of this decrease in TF expression has yet to be delineated, but is presently under investigation.

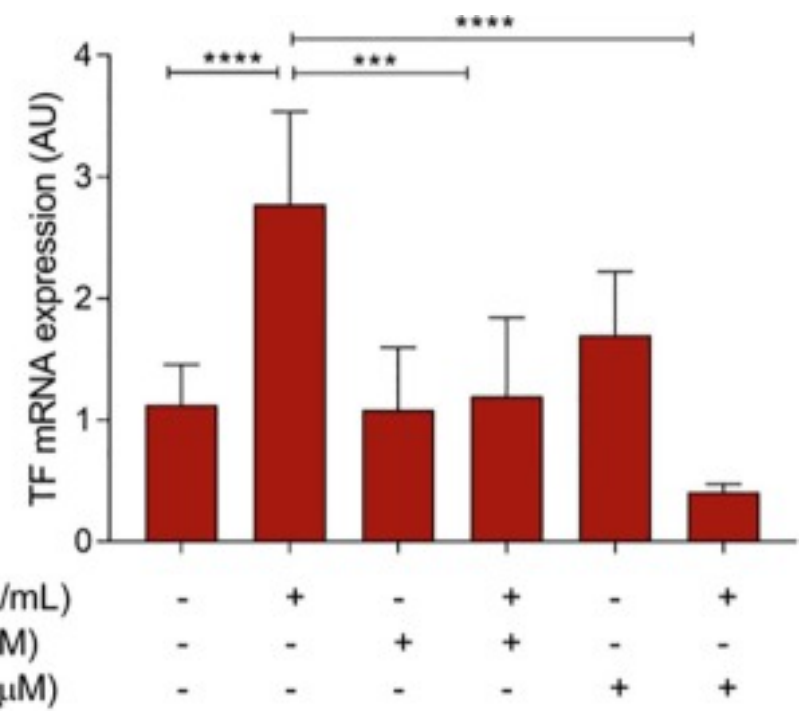

Figure 7. qPCR assay $(n=3)$ measuring the inhibition of TNF- $\alpha(25 \mathrm{ng} / \mathrm{mL})$ induced TF expression in HUVEC after treatment with ML161 and NRD-21 $(10 \mu \mathrm{M})$. Inhibitors were added at $\mathrm{t}=0, \mathrm{TNF}-\alpha$ was added at $\mathrm{t}=1 \mathrm{~h}$, and mRNA was measured at $\mathrm{t}=4 \mathrm{~h}$. Data was analyzed with one-way ANOVA followed by Bonferroni's multiple comparisons test. ${ }^{*} \mathrm{P}<0.05,{ }^{* *} \mathrm{P}<0.01,{ }^{* * *} \mathrm{P}<0.001,{ }^{* * * * \mathrm{P}}<0.0001$.

With these promising results in hand with NRD-21, we measured its stability and a number of parameters relevant to its use as an in vivo probe (Table 5). Importantly, NRD-21 is much more plasma stable than ML161. After $4 \mathrm{~h}$ in mouse plasma, $32 \%$ of NRD-21 remained, while ML161 was $<1 \%$. Improved stability in human plasma was also observed for NRD-21 (97\% vs $79 \%$ after $4 \mathrm{~h}$ ), as shown in Figure 8 . As with ML161, NRD-21 also shows excellent stability in the presence of human liver microsomes, with no apparent degradation after $1 \mathrm{~h}$. It 
also shows no measurable toxicity in a human cell line (hepG2). An area for improvement remains the low solubility of the current lead compounds of this class, with a solubility of $17 \mu \mathrm{M}$ for NRD-21 in a kinetic aqueous solubility assay with $2.5 \%$ DMSO. Both compounds were also profiled for off-target receptor binding by the Psychoactive Drug Screening Program (PDSP)..$\underline{32}$ Both modified radioligand binding to 3 or 4 different targets, including inhibition of binding to the peripheral benzodiazepine receptor (PBR) and activation of the serotonin transporter (SERT).

Table 5. Comparison of ML161 and NRD-21.

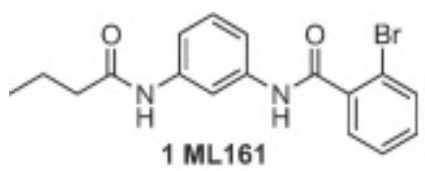

ML161

PAR1 iCa ${ }^{2+}$ assay ${ }^{\mathrm{a}}$

Average $\mathrm{IC}_{50} \pm \mathrm{SEM}$

Plasma stability

Microsomal stability

Kinetic aqueous solubility

(2.5\% DMSO)

PAR2 activity?

Off-target effects ${ }^{b}$

Cytotoxicity $\left(\mathrm{CC}_{50}\right)$ (human

hepG2 cells)

Reversible?
$0.57 \pm 0.08 \mu \mathrm{M}(\mathrm{n}=10)$

$<1 \%$ ( $4 \mathrm{~h}$, mouse) $79 \%$ ( $4 \mathrm{~h}$, human)

$99 \%$ (1 h, human)

$24 \mu \mathrm{M}$

None observed

4: Beta1 $=49 \%$; Beta3 $=32 \%$;

$\mathrm{PBR}=84 \% ; \mathrm{SERT}=-44 \%$

$>150 \mu \mathrm{M}$

Yes

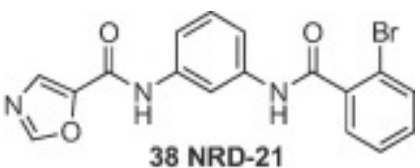

NRD-21

$0.37 \pm 0.13 \mu \mathrm{M}(\mathrm{n}=6)$

$32 \%$ (4 h, mouse) $97 \%$ (4 h, human)

$99 \%$ ( $1 \mathrm{~h}$, human)

$17 \mu \mathrm{M}$

None observed

3: $5 \mathrm{HT}-5 \mathrm{~A}=-31 \%$; NET = 31\%;

$\mathrm{PBR}=67 \% ; \mathrm{SERT}=-44 \%$

$>150 \mu \mathrm{M}$

Yes

a. Average of independent assays, each with $\mathrm{IC}_{50} \mathrm{~s}$ determined from curve fits with $\mathrm{n}=3$. See e.g. Table 1 for more details. ${ }^{b}$ Fraction of off-targets for which there is $>20 \%$ inhibition (at $10 \mu \mathrm{M}$ concentration) of 41 targets from the Psychoactive Drug Screening Program. ${ }^{b}$ Number of off-targets (out of 44 ) for which there is $>30 \%$ inhibition or activation of standard radioligand binding (at $10 \mu \mathrm{M}$ concentration) of 44 targets from the Abbreviations of target names with mean \% inhibition of binding are given. 5HT = 5hydroxytryptamine receptor; Beta $=\beta$-adrenoceptor; NET = norepinephrine transporter; $\mathrm{PBR}=$ peripheral benzodiazepine receptor (rat); SERT = serotonin transporter. Off-target assays were performed by the National Institute of Health Psychoactive Drug Screening Program (PDSP).

ML161

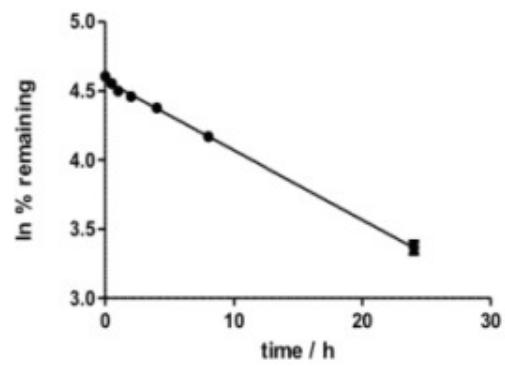

NRD-21

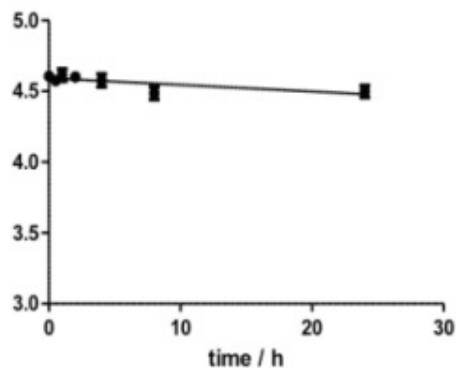

Figure 8. Human plasma stability of ML161 (left) and NRD-21 (right). Points indicate the natural logarithm of the average of 3 replicates at each time point.

\section{Discussion}

Our SAR studies at the western end of the 1,3-diaminobenzene scaffold have determined that lipophilic groups of limited size are best able to inhibit PAR1-driven Gq signaling. However, some heteroatom functionality is tolerated, with western heterocycles giving the most promising profiles. The oxazole NRD-21 was identified as a 
compound with slightly improved potency over our previous lead compound ML161, but with much improved plasma stability, making it more suitable for in vivo studies.

Most notably, NRD-21 is highly efficacious in the inhibition of TNF- $\alpha$-mediated TF expression in endothelium, making it a promising lead within this new class of parmodulin anti-inflammatory agents. The signaling pathway(s) leading to the anti-inflammatory effects of the parmodulins is not fully understood, but Flaumenhaft has published evidence consistent with a PAR1-mediated (via G $\beta \gamma$ ) signaling pathway that ultimately drives

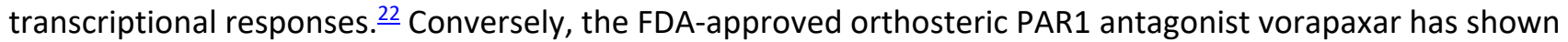
deleterious effects in cultured endothelium, including increased levels of apoptosis and decreased barrier integrity. $\underline{\underline{21}}$ We have also demonstrated, here and previously, $21, \underline{24}$ that unlike vorapaxar, parmodulins are readily reversible inhibitors of PAR1, which is an important safety consideration for anti-thrombotic agents. NRD-21 also inhibited human platelet aggregation similarly to ML161. We conclude that the parmodulin class of intracellular allosteric ligands of PAR1, exemplified by NRD-21 with its 1,3-diaminobenzene scaffold, is promising for both anti-thrombotic and anti-inflammatory-related indications. Efforts are ongoing to identify additional potent parmodulins, characterize their signaling pathway(s), and further investigate their utility in thrombosis and inflammation-related and proliferative disorders.

\section{Experimental section}

\subsection{General synthetic information}

All reagents and solvents, including anhydrous solvents, were purchased from commercial vendors and used as received. Deionized water was purified by charcoal filtration to a minimum resistance of $15 \mathrm{M} \Omega$ and used for reaction workups and in reactions with water. NMR spectra were recorded on Varian $300 \mathrm{MHz}$ or $400 \mathrm{MHz}$ spectrometers as indicated. Proton and carbon chemical shifts are reported in parts per million (ppm; $\delta$ ) relative to tetramethylsilane $\left({ }^{1} \mathrm{H} \delta 0\right)$, or $\mathrm{CDCl}_{3}\left({ }^{13} \mathrm{C} \delta 77.16\right),\left(\mathrm{CD}_{3}\right)_{2} \mathrm{CO}\left({ }^{1} \mathrm{H} \delta 2.05,{ }^{13} \mathrm{C} \delta 29.84\right), \mathrm{d}_{6}$-DMSO $\left({ }^{1} \mathrm{H} \delta 2.50,{ }^{13} \mathrm{C} \delta\right.$ 39.5), or $\mathrm{CD}_{3} \mathrm{OD}\left({ }^{1} \mathrm{H} \delta 3.31,{ }^{13} \mathrm{C} \delta 49.00\right)$. NMR data are reported as follows: chemical shifts, multiplicity (obs = obscured, $a p p=$ apparent, $b r=$ broad, $s=$ singlet, $d=$ doublet, $\mathrm{t}=$ triplet, $\mathrm{q}=$ quartet, $\mathrm{m}=$ multiplet, comp = complex overlapping signals); coupling constant(s) in $\mathrm{Hz}$; integration. Unless otherwise indicated, NMR data were collected at $25^{\circ} \mathrm{C}$. Filtration was performed by vacuum using VWR Grade 413 filter paper, unless otherwise noted. Flash chromatography was performed using Biotage SNAP cartridges filled with 40-60 $\mu \mathrm{m}$ silica gel on Biotage Isolera automated chromatography systems with photodiode array UV detectors. Analytical thin layer chromatography (TLC) was performed on Agela Technologies $0.25 \mathrm{~mm}$ glass plates with $0.25 \mathrm{~mm}$ silica gel. Visualization was accomplished with UV light $(254 \mathrm{~nm})$ and $\mathrm{KMnO}_{4}$ stain, unless otherwise noted. Chemical names were generated and select chemical properties were calculated using either ChemAxon Marvin suite or ChemDraw Professional 15.1. NMR data were processed using either MestreNova or ACD/NMR Processor Academic Edition using the JOC report format. High-resolution mass spectra (HRMS) were obtained from the University of Cincinnati Environmental Analysis Service Center using an Agilent 6540 Accurate-Mass LC-MS with Q-TOF.

\subsection{LC-MS characterization methods}

Tandem liquid chromatography/mass spectrometry (LC-MS) was performed on a Shimadzu LCMS-2020 with autosampler, photodiode array detector, and single-quadrupole MS with ESI and APCI dual ionization using a Peak Scientific nitrogen generator.

\subsubsection{Method A}

Column: Phenomenex Gemini $C_{18}(100 \times 4.6 \mathrm{~mm}, 3 \mu \mathrm{m}$ particle size, $110 \AA ̊$ pore size $)$

\section{Column temperature: $40^{\circ} \mathrm{C}$}

Sample Injection: 1-5 $\mu \mathrm{L}$ of sample in $\mathrm{MeCN}$ or $\mathrm{MeOH}$ 
Chromatographic monitoring: UV absorbance at 210 or $254 \mathrm{~nm}$

Mobile Phase: Solvent A: $\mathrm{H}_{2} \mathrm{O}$ w/ 0.1\% formic acid; Solvent B: $\mathrm{MeOH}$ w/ 0.1\% formic acid

Flow Rate: $1.0 \mathrm{~mL} / \mathrm{min}$

Gradient: 0 to $0.1 \mathrm{~min}: 25 \% \mathrm{MeOH}$ (Isocratic)

$0.1 \mathrm{~min}$ to $5 \mathrm{~min}: 25 \%$ to $95 \% \mathrm{MeOH}$ (Gradient)

5 min to $7 \mathrm{~min}: 95 \% \mathrm{MeOH}$ (Isocratic)

\subsubsection{Method B}

Column: Phenomenex Gemini $C_{18}(100 \times 4.6$ mm, $3 \mu \mathrm{m}$ particle size, $110 \AA ̊$ pore size $)$

Column temperature: $40^{\circ} \mathrm{C}$

Sample Injection: 1-5 $\mu \mathrm{L}$ of sample in $\mathrm{MeCN}$ or $\mathrm{MeOH}$

Chromatographic monitoring: UV absorbance at 210 or $254 \mathrm{~nm}$

Mobile Phase: Solvent A: $\mathrm{H}_{2} \mathrm{O}$ w/ 0.1\% formic acid; Solvent B: MeCN w/ 0.1\% formic acid

Flow Rate: $1.0 \mathrm{~mL} / \mathrm{min}$

Gradient: 0 to $0.1 \mathrm{~min}$ : 50\% MeCN (Isocratic)

$0.1 \mathrm{~min}$ to $5 \mathrm{~min}: 50 \%$ to $95 \% \mathrm{MeCN}$ (Gradient)

$5 \mathrm{~min}$ to $7 \mathrm{~min}$ : $95 \% \mathrm{MeCN}$ (Isocratic)

\subsubsection{Method C}

Column: Phenomenex Gemini $C_{18}(100 \times 4.6 \mathrm{~mm}, 3 \mu \mathrm{m}$ particle size, $110 \AA ̊$ pore size $)$

Column temperature: $40^{\circ} \mathrm{C}$

Sample Injection: 1-5 $\mu \mathrm{L}$ of sample in $\mathrm{MeCN}$ or $\mathrm{MeOH}$

Chromatographic monitoring: UV absorbance at 210 or $254 \mathrm{~nm}$

Mobile Phase: Solvent A: $\mathrm{H}_{2} \mathrm{O}$ w/ 0.1\% formic acid; Solvent B: MeCN w/ 0.1\% formic acid

Flow Rate: $1.0 \mathrm{~mL} / \mathrm{min}$

Gradient: 0 to $0.5 \mathrm{~min}: 50 \% \mathrm{MeCN}$ (Isocratic)

0.5 min to $4 \mathrm{~min}: 50 \%$ to $95 \%$ MeCN (Gradient)

$4 \mathrm{~min}$ to $6.3 \mathrm{~min}: 95 \% \mathrm{MeCN}$ (Isocratic)

\subsection{General procedures for synthesis of parmodulins via amide coupling.}

\subsubsection{Method A: Amide coupling using EDC}

To a round bottom flask with stir bar under nitrogen were added the appropriate carboxylic acid and anhydrous DCM/DMF (85:15; 0.2-0.6 M). The amine $\mathrm{HCl}$ salt to be coupled (1.2 eq.), HOBt (1.2 eq.), EDC- $\mathrm{HCl}$ (1.2 eq.), and 
DIPEA (2.1 eq.) were added and the reaction was stirred under nitrogen until complete, as measured by TLC and/or LC-MS. The reaction was diluted with DCM, washed with saturated aq. $\mathrm{NaHCO}_{3}, 1 \mathrm{M}$ aq. $\mathrm{HCl}$, and brine, then dried over $\mathrm{Na}_{2} \mathrm{SO}_{4}$, filtered, and concentrated under reduced pressure prior to purification by flash chromatography $\left(\mathrm{SiO}_{2}\right)$. The following parmodulins were synthesized utilizing this method: 3, 6, 8, 9, 13, 17, 25, and 35 .

\subsubsection{Method B: Conversion to the acid chloride and subsequent acylation}

To an oven-dried round bottom flask with stir bar under nitrogen were added the carboxylic acid, dry DCM, and $3 \AA$ A molecular sieves. Oxalyl chloride (1.2 eq.) and a catalytic amount of DMF (1-2 mol \%) were added and the reaction was stirred while attached to a bubbler (to monitor production of $\mathrm{CO}_{2}$ ) at $20{ }^{\circ} \mathrm{C}$ for $2-3 \mathrm{~h}$. The amine $\mathrm{HCl}$ salt (1 eq.) in DCM and DIPEA (2 eq.) were added and the reaction was stirred under nitrogen for $3-6 \mathrm{~h}$. The reaction was diluted with EtOAc and washed with half-saturated aq. $\mathrm{NaHCO}_{3}, 1 \mathrm{M} \mathrm{HCl}(30 \mathrm{~mL})$, and brine, then dried over $\mathrm{Na}_{2} \mathrm{SO}_{4}$, filtered, and concentrated under reduced pressure prior to purification by flash

chromatography $\left(\mathrm{SiO}_{2}\right)$. The following parmodulins were synthesized utilizing this method: 7, 11, 18, and 36-40.

\subsubsection{Method C: Acylation}

To an oven-dried round bottom flask with stir bar and under nitrogen were added the acid chloride, dry DCM, and $3 \AA$ molecular sieves. The amine $\mathrm{HCl}$ salt (1 eq.) in DCM and DIPEA (2 eq.) were added and the reaction was stirred under nitrogen for 3-6 h. The reaction was diluted with EtOAc and washed with half-saturated aq. $\mathrm{NaHCO}_{3}, 1 \mathrm{M} \mathrm{HCl}\left(30 \mathrm{~mL}\right.$ ), brine, dried over $\mathrm{Na}_{2} \mathrm{SO}_{4}$, filtered, and concentrated under reduced pressure to give crude product. The following parmodulins were synthesized utilizing this method: 10, 12, 19, and 24.

\subsubsection{Method D: Amide coupling using HATU}

To a round bottom flask with stir bar under nitrogen was added the carboxylic acid and anhydrous DCM. The amine (1.2 eq.), HATU (1.2 eq.), and DIPEA (1.2 eq.) were added and the reaction was stirred under nitrogen. The reaction was diluted with $\mathrm{DCM}(75 \mathrm{~mL})$ and washed with saturated $\mathrm{NaHCO}_{3}, 1 \mathrm{M} \mathrm{HCl}(30 \mathrm{~mL})$, brine, dried over $\mathrm{Na}_{2} \mathrm{SO}_{4}$, filtered, and concentrated under reduced pressure to give crude material. The following parmodulins were synthesized utilizing this method: 14-16, 31, and 33.

\subsection{Preparation of $\mathrm{N}$-[3-(2-bromobenzamido)phenyl]-1,3-oxazole-5-carboxamide (38, NRD-21, Scheme S1)}

To a vial with a magnetic stir bar was added aniline $\mathbf{S 3}(50.2 \mathrm{mg}, 0.173 \mathrm{mmol})$, oxazole-5-carboxylic acid ( $27 \mu \mathrm{L}$, $0.347 \mathrm{mmol}), \mathrm{EDC}-\mathrm{HCl}(33.9 \mathrm{mg}, 0.177 \mathrm{mmol})$, and HOBt $(26.7 \mathrm{mg}, 0.174)$. The vial was sealed and flushed with nitrogen for 5 min., then DCE $(1.5 \mathrm{~mL})$ and DMF $(0.5 \mathrm{~mL})$ were added. To the resulting solution was added a $10 \%$ solution of pyridine in DCE $(0.14 \mathrm{~mL}, 0.173 \mathrm{mmol})$ by syringe, and the reaction was stirred for $24 \mathrm{~h}$. A sample aliquot was taken from the reaction, concentrated under reduced pressure, dissolved in a minimal amount of HPLC grade MeCN, and analyzed by LC-MS to confirm reaction completion. The reaction was then diluted with EtOAc $(30 \mathrm{~mL})$ and washed with half-saturated aq. $\mathrm{NaHCO}_{3}(3 \times 15 \mathrm{~mL})$, brine $(2 \times 10 \mathrm{~mL})$, dried over $\mathrm{Na}_{2} \mathrm{SO}_{4}$, filtered, and concentrated under reduced pressure. The crude product was dissolved in a minimal amount of DCM, loaded onto a $10 \mathrm{~g}$ silica gel column, and purified by flash chromatography (MeOH:DCM, 0-8\%) to give 38 as a yellow oil (40 mg, 60\%). TLC: mobile phase: $\mathrm{MeOH:DCM} \mathrm{(6:94),} R_{f}=0.30 ; L C-M S t_{R}=4.29$ min. (Characterization Method A); $m / z=387.29(\mathrm{M}+\mathrm{H}) ;{ }^{1} \mathrm{H}$ NMR $\left(300 \mathrm{MHz}, \mathrm{CD}_{3} \mathrm{OD}\right) \delta=8.36(\mathrm{~s}, 1 \mathrm{H}), 8.15(\mathrm{t}$, $J=2.0 \mathrm{~Hz}, 1 \mathrm{H}), 7.85(\mathrm{~s}, 1 \mathrm{H}), 7.64(\mathrm{dd}, J=1.0,7.9 \mathrm{~Hz}, 1 \mathrm{H}), 7.53-7.41(\mathrm{~m}, 5 \mathrm{H}), 7.41-7.28(\mathrm{~m}, 3 \mathrm{H}) ;{ }^{13} \mathrm{C} \mathrm{NMR}$ $\left(100 \mathrm{MHz}, \mathrm{CD}_{3} \mathrm{OD}\right) \delta=169.1,157.2,154.7,147.0,140.2,140.1,139.3,134.2,132.3,131.2,130.2,129.8,128.7$, 120.5, 118.5, 118.1, 114.4. HRMS (ESI ${ }^{+}$) calculated for $\mathrm{C}_{17} \mathrm{H}_{12} \mathrm{BrN}_{3} \mathrm{O}_{3}(\mathrm{M}+\mathrm{H}) 386.0135$, found 386.0147. 


\title{
Author contributions
}

D.M.G. and R.R. contributed equally to this manuscript. Conceived project: C.D.; Designed compounds: C.D., D.M.G., R.R.; Synthesized and characterized analogs: D.M.G., R.R., N.D.-R.D., E.G., A.S., K.M.K., T.H.Y.Y., K.E.K.; Performed pharmacology and analyzed data: D.M.G., R.R. C.D.; Performed physicochemical/physiochemical profiling: E.D., L.A.A.; Performed RNA assay and analyzed related data: S.S., H.W; Wrote manuscript: C.D., R.R.; Prepared Supporting Information and edited the manuscript: R.R., D.M.G., C.D., L.A.A., S.S., E.G.

\section{Funding sources}

C.D. thanks the National Heart, Lung, and Blood Institute (NHLBI) (R15HL127636) for support, and Marquette University for startup funding. H.W. and S.S. thank NHLBI for funding (R01HL133348). K.M.K. (Honors Program), D.M.G., and R.R. thank Marquette University for summer support. N.D.-R.D thanks the National Science Foundation (via Milwaukee Area Technical College BEST program) for a fellowship.

\section{Notes}

A patent application describing compounds reported in this manuscript has been submitted. C.D. is an inventor on a patent (WO 2012/040636) containing previously reported compounds included in this paper. An earlier version of this manuscript was posted to the preprint server ChemRxiv. $\underline{3}$

\section{Acknowledgments}

We thank Irene Hernandez, and Trudy Holyst (Blood Research Institute) for assistance with cell culture and assay troubleshooting, Dr. Peter Newman and Dr. Huiying Zhi (Blood Research Institute) for assistance with the platelet aggregation assay, and Dr. Sheng Cai and Dennis Wiedenhoeft (Marquette University) for assistance with LC-MS and NMR instruments. We thank ACD/Labs (NMR processing) and ChemAxon (NMR prediction and compound naming and property prediction) for providing access to software. Receptor binding profiles were provided by the National Institute of Mental Health's Psychoactive Drug Screening Program, Contract \# HHSN271-2018-00023-C (NIMH PDSP). The NIMH PDSP is Directed by Bryan L. Roth MD, PhD at the University of North Carolina at Chapel Hill and Project Officer Jamie Driscoll at NIMH, Bethesda MD, USA.

\section{Appendix A. Supplementary data}

The Parmodulin NRD-21 is an Allosteric Inhibitor of PAR1 Gq Signaling with Improved Anti-Inflammatory Activity and Stability

Disha M. Gandhi ${ }^{\S}$

Department of Chemistry, Marquette University, P.O. Box 1881, Milwaukee, WI, 53201-1881, USA

Ricardo Rosas, Jr. ${ }^{\S}$

Department of Chemistry, Marquette University, P.O. Box 1881, Milwaukee, WI, 53201-1881, USA

\section{Eric Greve}

Department of Chemistry, Marquette University, P.O. Box 1881, Milwaukee, WI, 53201-1881, USA

\section{Kaitlin Kentala}

Department of Chemistry, Marquette University, P.O. Box 1881, Milwaukee, WI, 53201-1881, USA

\author{
N'Guessan D.-R. Diby
}

Department of Chemistry, Marquette University, P.O. Box 1881, Milwaukee, WI, 53201-1881, USA 
Vladyslava A. Snyder

Department of Chemistry, Marquette University, P.O. Box 1881, Milwaukee, WI, 53201-1881, USA

Allison Stephans

Department of Chemistry, Marquette University, P.O. Box 1881, Milwaukee, WI, 53201-1881, USA

Teresa H. W. Yeung

Department of Chemistry, Marquette University, P.O. Box 1881, Milwaukee, WI, 53201-1881, USA

Elliot DiMilo

Department of Chemistry and Biochemistry, Milwaukee Institute for Drug Discovery, University of Wisconsin,

Khia E. Kurtenbach

Department of Chemistry, Marquette University, P.O. Box 1881, Milwaukee, WI, 53201-1881, USA

\section{Leggy A. Arnold}

Department of Chemistry and Biochemistry, Milwaukee Institute for Drug Discovery, University of Wisconsin,

\section{Saravanan Subramaniam}

Blood Research Institute, BloodCenter of Wisconsin, Milwaukee, WI, 53226, USA

\section{Hartmut Weiler}

Blood Research Institute, BloodCenter of Wisconsin, Milwaukee, WI, 53226, USA

Department of Physiology, Medical College of Wisconsin, Milwaukee, WI, 53226, USA

\section{Chris Dockendorff*}

Department of Chemistry, Marquette University, P.O. Box 1881, Milwaukee, WI, 53201-1881, USA

$\S$ These authors contributed equally to this manuscript.

*christopher.dockendorff@mu.edu

\section{Abbreviations}

$\begin{array}{ll}\text { AcOH } & \text { acetic acid } \\ \text { aPC } & \text { activated protein C } \\ \text { conc. } & \text { concentrated } \\ \text { Boc } & \text { tert-butoxycarbonyl (protecting group) } \\ \text { DCE } & \text { 1,2-dichloroethane (solvent) } \\ \text { DCM } & \text { dichloromethane (solvent) } \\ \text { DIC } & \text { disseminated intravascular coagulation } \\ \text { DMAP } & \text { 4-dimethylaminopyridine (nucleophilic catalyst) } \\ \text { DMF } & N, N \text {-dimethylformamide (solvent) } \\ \text { DMSO } & \text { dimethylsulfoxide (solvent) } \\ \text { EDC } & \text { 1-ethyl-3-(3-dimethylaminopropyl)carbodiimide (amide coupling reagent) } \\ \text { DIPEA } & N, N \text {-diisopropylethylamine (base) } \\ \text { EtOAC } & \text { ethyl acetate (solvent) } \\ \text { FBS } & \text { fetal bovine serum }\end{array}$




\begin{tabular}{ll} 
GFP & green fluorescent protein \\
GPCR & G-protein coupled receptor \\
HATU & 1-[bis(dimethylamine)methylene]-1H-1,2,3-triazolo[4,5-b]pyridinium 3-oxid \\
& hexafluorophosphate (amide coupling reagent) \\
HBSS & Hank's balanced salt solution \\
HEPES & 4-(2-hydroxyethyl)-1-piperazine-ethanesulfonic acid (buffering agent) \\
HOBt & 1-hydroxybenzotriazole (additive for amide coupling) \\
HPLC & high performance liquid chromatography \\
HTS & high-throughput screening \\
HUVEC & human umbilical vein cells \\
iCa2+ & intracellular calcium mobilization \\
IC50 & half-maximal inhibitory concentration \\
IPA & isopropyl alcohol \\
LCMS & liquid chromatography-mass spectrometry \\
NMR & nuclear magnetic resonance \\
MI & myocardial infarction \\
MeCN & acetonitrile (solvent) \\
PAR & protease-activated receptor \\
Pd/C & palladium on carbon (charcoal) \\
PGE1 & prostaglandin E1 \\
Phe & phenylalanine \\
PRP & platelet-rich plasma \\
SAR & structure-activity relationship \\
SEM & standard error of the mean \\
TEA & triethylamine (base) \\
TFA & trifluoroacetic acid \\
THF & tetrahydrofuran (solvent) \\
TNF- $\alpha$ & Tumor Necrosis Factor-alpha \\
& \\
& \\
\hline
\end{tabular}

\section{Assay protocols}

a) Intracellular calcium mobilization assay

All assays, including washing studies, were run according to our previously published protocol. ${ }^{1}$

b) Platelet aggregation assay

Tyrode's buffer preparation:

\begin{tabular}{|l|l|}
\hline $137 \mathrm{mM} \mathrm{NaCl}$ & $4 \mathrm{~g}$ \\
\hline $20 \mathrm{mM} \mathrm{HEPES}$ & $2.6 \mathrm{~g}$ \\
\hline $13.8 \mathrm{mM} \mathrm{NaHCO}$ & $0.58 \mathrm{~g}$ \\
\hline $2.5 \mathrm{mM} \mathrm{KCl}$ & $0.093 \mathrm{~g}$ \\
\hline $0.36 \mathrm{mM} \mathrm{NaH}_{2} \mathrm{PO}_{4}$ & $0.0216 \mathrm{~g}$ \\
\hline & $500 \mathrm{~mL} \mathrm{pH} 7.4$ \\
\hline
\end{tabular}

Just before use, $0.25 \% \mathrm{BSA}$ and $0.1 \%$ glucose were added.

Human platelet-rich plasma (PRP) preparation:

Whole blood $(10 \mathrm{~mL}$ ) was collected from a volunteer. The blood was diluted with an equal volume of Tyrode's buffer $(10 \mathrm{~mL})$ and then transferred into two $17 \times 100 \mathrm{~mm}$ tubes and $50 \mathrm{ng} / \mathrm{mL}$ of PGE1 (final concentration) was added. The samples were centrifuged in a Beckman GS-6 at $200 \mathrm{~g}(1700 \mathrm{rpm})$ for 7 minutes at room temperature. After completion, the PRP was removed and transferred to a new set of $17 \times 100$ tubes, then $2 \mathrm{mM}$ 
EDTA (final concertation) and $40 \mathrm{uL}$ per $10 \mathrm{~mL}$ of $0.5 \mathrm{M}$ EDTA were added. The cells were again centrifuged at $700 \mathrm{~g}$ (1700 rpm) for 10 minutes at room temperature. The platelet cells were resuspended in Tyrode's buffer containing $50 \mathrm{ng} / \mathrm{mL}$ PGE1 and $2 \mathrm{mM}$ EDTA. A small aliquot of platelet cells was taken for cell counting with a Scil Vet $A B C$ Hematology Analyzer. After counting, the suspension was centrifuged at $700 \mathrm{~g}(1700 \mathrm{rpm})$ for $10 \mathrm{~min}$. at room temperature, and then resuspended in Tyrode's buffer at $1 \times 108$ cells per $\mathrm{mL}$.

\section{Platelet aggregation:}

Platelet aggregation was measured using a whole-blood lumi-aggregometer (Chrono-Log). Platelet cells in Tyrode's buffer $(300 \mu \mathrm{L})$ were transferred to a siliconized glass cuvette at $37^{\circ} \mathrm{C}$ with constant stirring at 1000 $\mathrm{rpm}$. The cells were dosed with a parmodulin ( $10 \mu \mathrm{M}$ final concentration) and incubated for $2 \mathrm{~min}$. The agonist SFLLRN-NH2 (1.5 $\mu \mathrm{M}$ final concentration) was then added to the cuvette and response was monitored for five minutes after the addition of the agonist.

\section{c) Tissue Factor gene expression assay}

EA.hy926 cells were seeded on a 12 well plate and treated with the parmodulins ML161 $(10 \mu M)$ and NRD-21(10 $\mu \mathrm{M})$ for 4 hours. Some wells received TNF- $\alpha(25 \mathrm{ng} / \mathrm{mL}) 1 \mathrm{~h}$ after the addition of parmodulins. At the end of the $4 \mathrm{~h}$ experiment, cells were washed with PBS, and total RNA was extracted using TRIzol (Life Technologies, Carlsbad, CA). RNA was reverse transcribed into cDNA using the QuantiTect ${ }^{\circledR}$ Reverse transcription kit (Qiagen), and the levels of tissue factor (TF) gene expression was quantified by Quantitative PCR reactions using TaqMan, consisting of $5 \mu \mathrm{L}$ TaqMan Fast Advanced Master Mix (Applied Biosystems), $0.5 \mu \mathrm{L}$ each of TF and GAPDH TaqMan primers/probes (final concentrations of $900 \mathrm{nM} / 250 \mathrm{nM}$, respectively), and 20-30 ng of genomic DNA $(1 \mu \mathrm{L})$ in a $20 \mu \mathrm{L}$ reaction. Thermal cycling conditions were as follows: 1 cycle of $95^{\circ} \mathrm{C}$ for $10 \mathrm{~min}$., followed by 50 cycles of $95^{\circ} \mathrm{C}$ for $10 \mathrm{~s}$ and $60^{\circ} \mathrm{C}$ for $20 \mathrm{~s}$. Real-time PCR primer/probes were purchased from Integrated DNA Technologies (Coralville, IA). TF Primers: forward 5'-ACCCGTCAATCAAGTCTACAC-3'; Reverse 5'GTCTGCTTCACATCCTTCACA-3'. GAPDH Primers: forward 5'- GGATTTGGTCGTATTGGG-3'; Reverse 5'GGAAGATGGTGATGGGATT-3'

Data was analyzed with one-way ANOVA followed by Bonferroni's multiple comparisons test. ${ }^{*} \mathrm{P}<0.05{ }^{* *} \mathrm{P}<0.01$, $* * * P<0.001, * * * * P<0.0001$.

\section{d) Plasma stability protocol}

Solid NRD-21 and ML-161 were dissolved in dimethyl sulfoxide (DMSO) to give $1 \mathrm{mM}$ solutions. Human plasma was incubated for $30 \mathrm{~min}$ at $37^{\circ} \mathrm{C}$ prior to the addition of each of the compounds. NRD-21 and ML-161 solutions were added to $490 \mu \mathrm{L}$ and $495 \mu \mathrm{L}$ aliquots of plasma to final concentrations of $20 \mu \mathrm{M}$ and $10 \mu \mathrm{M}$ respectively. Three replicates for each compound were incubated for $24 \mathrm{~h}$ at $37^{\circ} \mathrm{C} .50 \mu \mathrm{L}$ aliquots of each sample were collected and quenched in $100 \mu \mathrm{L}$ of methanol stored on ice at seven time points of $0 \mathrm{~min}, 30 \mathrm{~min}, 1 \mathrm{~h}, 2 \mathrm{~h}, 4 \mathrm{~h}$, $8 \mathrm{~h}$, and $24 \mathrm{~h}$. Samples were vortexed and centrifuged at 12,000 rpm. The supernatant was collected and loaded on a $0.2 \mu \mathrm{m}$ nylon filter plate for vacuum filtration. $50 \mu \mathrm{L}$ of the filtrate was diluted in $100 \mu \mathrm{L}$ of methanol containing $300 \mathrm{nM}$ 4,5-diphenylimidazole (4,5-DPI) as an internal standard. 


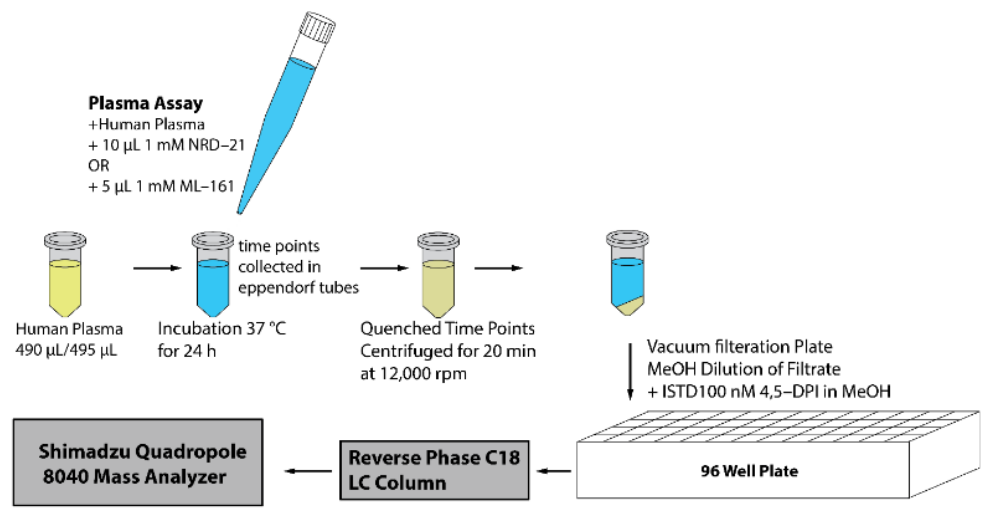

\section{Synthetic procedures}

\section{a) General information}

All reagents and solvents, including anhydrous solvents, were purchased from commercial vendors and used as received. Deionized water was purified by charcoal filtration to a minimum resistance of $15 \mathrm{M} \Omega$ and used for reaction workups and in reactions with water. NMR spectra were recorded on Varian $300 \mathrm{MHz}$ or $400 \mathrm{MHz}$ spectrometers as indicated. Proton and carbon chemical shifts are reported in parts per million (ppm; $\delta$ ) relative to tetramethylsilane $(1 \mathrm{H} \delta 0)$, or CDCl3 (13C $\delta 77.16)$, (CD3)2CO (1H $\delta 2.05,13 \mathrm{C} \delta 29.84)$, d6-DMSO (1H $\delta 2.50$, $13 \mathrm{C} \delta 39.5)$, or CD3OD $(1 \mathrm{H} \delta 3.31,13 \mathrm{C} \delta 49.00)$. NMR data are reported as follows: chemical shifts, multiplicity (obs = obscured, $a p p=$ apparent, $b r=$ broad, $s=$ singlet, $d=$ doublet, $\mathrm{t}=$ triplet, $q=$ quartet, $\mathrm{m}=$ multiplet, comp = complex overlapping signals); coupling constant(s) in $\mathrm{Hz}$; integration. Unless otherwise indicated, NMR data were collected at $25^{\circ} \mathrm{C}$. Filtration was performed by vacuum using VWR Grade 413 filter paper, unless otherwise noted. Flash chromatography was performed using Biotage SNAP cartridges filled with $40-60 \mu \mathrm{m}$ silica gel on Biotage Isolera automated chromatography systems with photodiode array UV detectors. Analytical thin layer chromatography (TLC) was performed on Agela Technologies $0.25 \mathrm{~mm}$ glass plates with $0.25 \mathrm{~mm}$ silica gel. Visualization was accomplished with UV light ( $254 \mathrm{~nm}$ ) and $\mathrm{KMnO} 4$ stain, unless otherwise noted. Chemical names were generated and select chemical properties were calculated using either ChemAxon Marvin suite or ChemDraw Professional 15.1. NMR data were processed using either MestreNova or ACD/NMR Processor Academic Edition using the JOC report format. High-resolution mass spectra (HRMS) were obtained from the University of Cincinnati Environmental Analysis Service Center using an Agilent 6540 Accurate-Mass LC-MS with Q-TOF.

\section{b) LC-MS characterization methods}

Tandem liquid chromatography/mass spectrometry (LC-MS) was performed on a Shimadzu LCMS-2020 with autosampler, photodiode array detector, and single-quadrupole MS with ESI and APCI dual ionization using a Peak Scientific nitrogen generator.

\section{Method A}

\section{Column:}

Column temperature:

Sample Injection:

Chromatographic monitoring:

Mobile Phase:

Flow Rate:

Gradient:
Phenomenex Gemini C18 (100 x 4.6 mm, $3 \mu \mathrm{m}$ particle size, $110 \AA ̊$ pore size)

$40{ }^{\circ} \mathrm{C}$

1-5 $\mu \mathrm{L}$ of sample in $\mathrm{MeCN}$ or $\mathrm{MeOH}$

UV absorbance at 210 or $254 \mathrm{~nm}$

Solvent A: $\mathrm{H} 2 \mathrm{O}$ w/ 0.1\% formic acid; Solvent B: $\mathrm{MeOH}$ w/ 0.1\% formic acid

$1.0 \mathrm{~mL} / \mathrm{min}$

0 to $0.1 \mathrm{~min}: 25 \% \mathrm{MeOH}$ (Isocratic)

$0.1 \mathrm{~min}$ to $5 \mathrm{~min}: 25 \%$ to $95 \% \mathrm{MeOH}$ (Gradient)

$5 \mathrm{~min}$ to $7 \mathrm{~min}: 95 \% \mathrm{MeOH}$ (Isocratic) 
Method B

Column:

Column temperature:

Sample Injection:

Chromatographic monitoring:

Mobile Phase:

Flow Rate:
Gradient:

Phenomenex Gemini $C_{18}(100 \times 4.6$ mm, $3 \mu \mathrm{m}$ particle size, $110 \AA ̊$ pore size)

$40^{\circ} \mathrm{C}$

1-5 $\mu \mathrm{L}$ of sample in $\mathrm{MeCN}$ or $\mathrm{MeOH}$

UV absorbance at 210 or $254 \mathrm{~nm}$

Solvent A: $\mathrm{H}_{2} \mathrm{O}$ w/ $0.1 \%$ formic acid; Solvent B: $\mathrm{MeCN}$ w/ $0.1 \%$ formic acid $1.0 \mathrm{~mL} / \mathrm{min}$

0 to 0.1 min: $50 \%$ MeCN (Isocratic)

0.1 min to 5 min: $50 \%$ to $95 \%$ MeCN (Gradient)

$5 \mathrm{~min}$ to $7 \mathrm{~min}$ : $95 \% \mathrm{MeCN}$ (Isocratic)

Method C

Column:

Column temperature:

Sample Injection:

Chromatographic monitoring:

Mobile Phase:

Flow Rate:

Gradient:
Phenomenex Gemini $\mathrm{C}_{18}(100 \times 4.6 \mathrm{~mm}, 3 \mu \mathrm{m}$ particle size, $110 \AA ̊$ pore size $)$

$40^{\circ} \mathrm{C}$

1-5 $\mu \mathrm{L}$ of sample in $\mathrm{MeCN}$ or $\mathrm{MeOH}$

UV absorbance at 210 or $254 \mathrm{~nm}$

Solvent A: $\mathrm{H}_{2} \mathrm{O}$ w/ 0.1\% formic acid; Solvent B: $\mathrm{MeCN}$ w/ 0.1\% formic acid

$1.0 \mathrm{~mL} / \mathrm{min}$

0 to $0.5 \mathrm{~min}: 50 \% \mathrm{MeCN}$ (Isocratic)

0.5 min to 4 min: $50 \%$ to $95 \%$ MeCN (Gradient)

4 min to $6.3 \mathrm{~min}: 95 \% \mathrm{MeCN}$ (Isocratic)

\section{c) Preparative HPLC purification methods}

Preparative liquid chromatography was performed on a Shimadzu LC-20AP preparative HPLC with autosampler, dual wavelength detector, and fraction collector.

Method A

Column:

Mobile Phase:

Peak collection:

Sample Injection:

Flow Rate:

Gradient:

Method B

Column:

Mobile Phase:

Peak collection:

Sample Injection:

Flow Rate:

Gradient:
Phenomenex Gemini C18 Semi Preparative Column ( 250 x 10 mm, $5 \mu \mathrm{m}$ particle size, $110 \AA$ A pore size)

Solvent A: $\mathrm{H}_{2} \mathrm{O}$ w/ $0.1 \%$ formic acid; Solvent B: $\mathrm{MeOH}$ w/ $0.1 \%$ formic acid measured by UV absorbance at 210 or $254 \mathrm{~nm}$

0.1-1.9 $\mathrm{mL}$ (2 $\mathrm{mL}$ sample loop) of sample in DMSO

$6.0 \mathrm{~mL} / \mathrm{min}$

0 to $1.5 \mathrm{~min}: 25 \% \mathrm{MeOH}$

$1.5 \mathrm{~min}$ to $8 \mathrm{~min}: 25 \%$ to $95 \% \mathrm{MeOH}$

$8 \min$ to $10.5 \min : 95 \% \mathrm{MeOH}$

Phenomenex Gemini $\mathrm{C}_{18}$ Semi Preparative Column $(250 \times 10 \mathrm{~mm}, 5 \mu \mathrm{m}$ particle size, $110 \AA$ A pore size)

Solvent A: $\mathrm{H}_{2} \mathrm{O}$ w/ $0.1 \%$ formic acid; Solvent B: $\mathrm{MeCN}$ w/ $0.1 \%$ formic acid measured by UV absorbance at 210 or $254 \mathrm{~nm}$

$0.1-1.9 \mathrm{~mL}$ ( $2 \mathrm{~mL}$ sample loop) of sample in DMSO

$6.0 \mathrm{~mL} / \mathrm{min}$

0 to $1.5 \mathrm{~min}: 25 \% \mathrm{MeCN}$

$1.5 \mathrm{~min}$ to $8 \mathrm{~min}: 25 \%$ to $95 \% \mathrm{MeCN}$

$8 \mathrm{~min}$ to $10.5 \mathrm{~min}: 95 \% \mathrm{MeCN}$ 
d) Synthetic schemes

Scheme S1. Synthesis of oxazole NRD-21

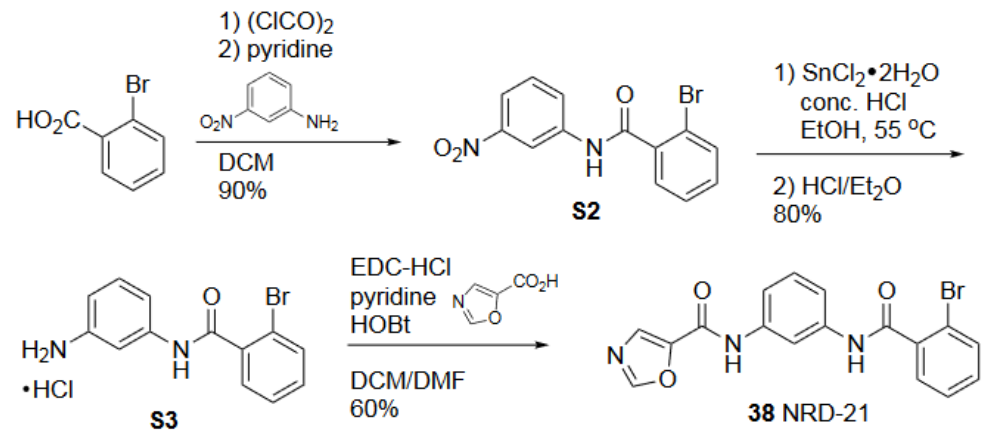

Scheme S2. Synthesis of butoxyphenylether TY-13

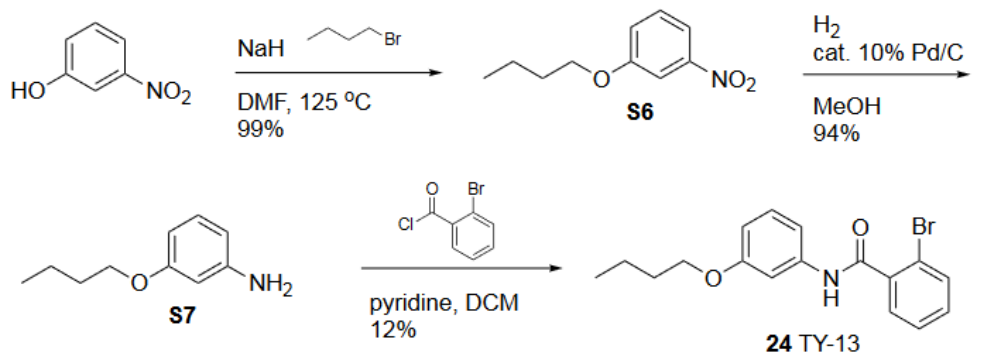

Scheme S3. Synthesis of methyl carbamate VAK-9<smiles>CCOC(C)(C)[N+](C)(C)CCOC(=O)Nc1cccc(NC(=O)c2ccccc2Br)c1</smiles>

Scheme S4. Synthesis of ethyl carbamate VAK-10<smiles>CCOC(=O)Nc1cccc(NC(=O)OCC)c1</smiles>

Scheme S5. Synthesis of secondary amine DG-75
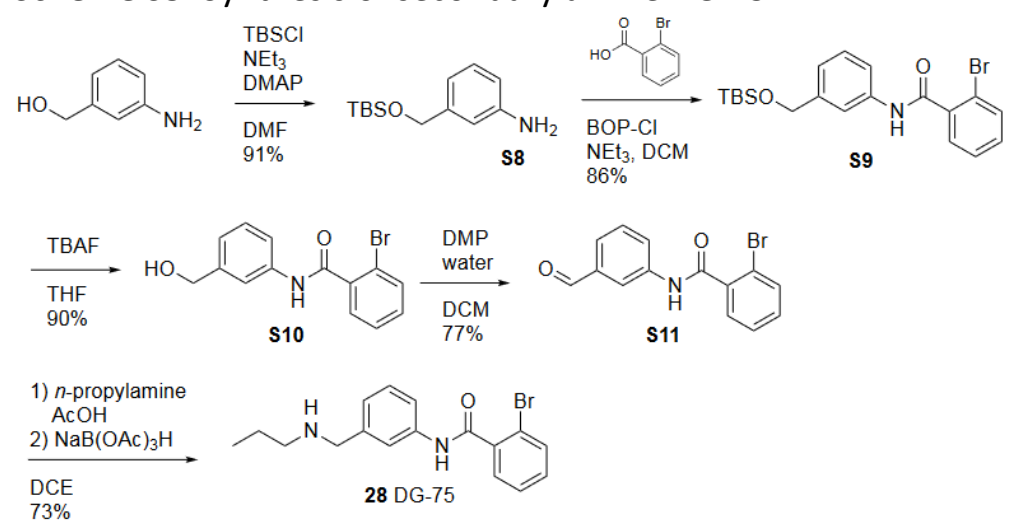

Scheme S6. Synthesis of pyrrolidine analog KMK-17 
<smiles>Nc1cccc(NC(=O)c2ccccc2Br)c1</smiles>

S3

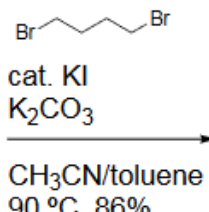

$90{ }^{\circ} \mathrm{C}, 86 \%$

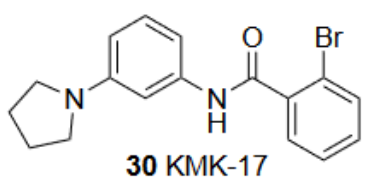

$30 \mathrm{KMK}-17$

e) Experimental procedures for select parmodulins<smiles>O=C(Nc1cccc([N+](=O)[O-])c1)c1ccccc1Br</smiles>

S2

\section{2-bromo- $N$-(3-nitrophenyl)benzamide (S2)}

S2 was synthesized according to a previously published protocol. ${ }^{2}$<smiles>Nc1cccc(NC(=O)c2ccccc2Br)c1</smiles>

\section{S3}

\section{$\mathrm{N}$-(3-aminophenyl)-2-bromobenzamide hydrochloride (S3)}

To a round bottom flask with stir bar was added a solution of $\mathrm{SnCl} 2 \cdot 2 \mathrm{H} 2 \mathrm{O}(6.15 \mathrm{~g}, 0.03 \mathrm{~mol})$ in conc. $\mathrm{HCl}(5 \mathrm{~mL})$. To this solution was added a solution of 2-bromo-N-(3-nitrophenyl)benzamide ( $\mathrm{S} 2,1.75 \mathrm{~g}, 0.01 \mathrm{~mol}$ ) in ethanol $(50 \mathrm{~mL})$, and the resulting suspension was stirred at $55^{\circ} \mathrm{C}$ for $2 \mathrm{~h}$. A sample aliquot was taken from the reaction, basified with $2 \mathrm{M}$ aq. $\mathrm{NaOH}$, filtered, and the filtrate was concentrated under reduced pressure, dissolved in a minimal amount of HPLC grade MeCN, and analyzed with LCMS to confirm reaction completion. The reaction was cooled to $20^{\circ} \mathrm{C}$, basified with $2 \mathrm{M}$ aq. $\mathrm{NaOH}$ (until pH 9), and filtered. The filtrate was concentrated under reduced pressure to half volume and then extracted with DCM $(150 \mathrm{~mL})$. The organic layer was washed with brine, dried over $\mathrm{Na} 2 \mathrm{SO} 4$, filtered, and concentrated under reduced pressure to give crude product. The crude material was dissolved in DCM and added to $0.9 \mathrm{M} \mathrm{HCl}$ in ether $(20 \mathrm{~mL})$ and stirred for $5 \mathrm{~min}$. at $20^{\circ} \mathrm{C}$ to form a precipitate. The precipitate was filtered, washed with DCM, collected, and dried to give aniline $\mathrm{HCl}$ salt $\mathrm{S} 3(1.6 \mathrm{~g}$, $81 \%)$ as a yellow solid. This compound has been previously reported and characterized (CAS\# 331445-38-6).

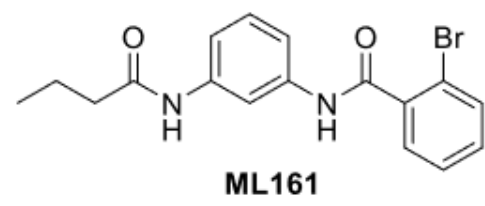

1

2-bromo-N-(3-butanamidophenyl)benzamide (1)

1 was synthesized according to a previously published protocol. ${ }^{2}$ 


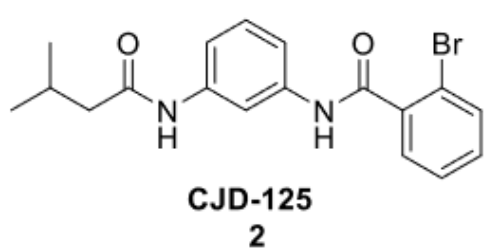

2-bromo-N-[3-(3-methylbutanamido)phenyl]benzamide (2)

2 was synthesized according to a previously published protocol. ${ }^{2}$<smiles>Cc1cccc(NC(=O)c2ccccc2Br)c1</smiles>

3

2-bromo-N-(3-cyclopentaneamidophenyl)benzamide (3)

$\mathbf{3}$ was synthesized according to a previously published protocol. ${ }^{2}$<smiles>CCCNC(=O)c1cccc(NC(=O)c2ccccc2Cl)c1</smiles>

3-(2-chlorobenzamido)-N-propylbenzamide (4)

4 was synthesized according to a previously published protocol. ${ }^{2}$<smiles></smiles>

5

2-bromo-N-[3-(butylamino)phenyl]benzamide (5)

5 was synthesized according to a previously published protocol. ${ }^{1}$<smiles>CCC(C)C(=O)Nc1cccc(NC(=O)c2ccccc2Br)c1</smiles>

2-bromo-N-[3-(2-methylbutanamido)phenyl]benzamide (7)

Analogue (7) was synthesized by coupling S3 with 2-methylbutanoyl chloride ( $59 \mathrm{mg}, 0.489 \mathrm{mmol}$ ) according to general method $B$. The crude material was dissolved in a minimal amount of DCM, loaded onto a $10 \mathrm{~g}$ silica column, and purified by flash chromatography (EtOAc:hexanes, $0-47 \%$ ) to give 7 as a white solid (80 $\mathrm{mg}$ ) in $44 \%$ yield. LC/MS tR $=5.57 \mathrm{~min}$ (Characterization Method A); $\mathrm{m} / \mathrm{z}=375.00(\mathrm{M}+\mathrm{H}) ; 1 \mathrm{H} \mathrm{NMR} \mathrm{(400} \mathrm{MHz,} \mathrm{(CD3)2CO)} \delta$ = 9.54 (br. s., $1 \mathrm{H}$ ), 9.22 (br. s., $1 \mathrm{H}), 8.16$ (br. s., $1 \mathrm{H}), 7.72-7.20$ (m, $7 \mathrm{H}), 2.51$ - $2.38(\mathrm{~m}, 1 \mathrm{H}), 1.78$ - $1.64(\mathrm{~m}, 1$ H), 1.51 - $1.37(m, 1 \mathrm{H}), 1.19-1.11(\mathrm{~m}, 3 \mathrm{H}), 0.97-0.86(\mathrm{~m}, 3 \mathrm{H})$. 
<smiles>O=C(CC(F)(F)F)Nc1cccc(NC(=O)c2ccccc2Br)c1</smiles>

\section{2-bromo-N-[3-(3,3,3-trifluoropropanamido)phenyl]benzamide (9)}

Analogue (9) was synthesized by coupling S3 with 3,3,3-trifluoropropanoic acid ( $15 \mu \mathrm{L}, 0.170 \mathrm{mmol}$ ) according to general method $\mathrm{A}$. The crude material was dissolved in a minimal amount of DCM, loaded onto a $5 \mathrm{~g}$ silica column, and purified by flash chromatography (EtOAc:hexanes, $0-80 \%$ ) to give 9 as a yellow oil (19 $\mathrm{mg}$ ) in $28 \%$ yield. $L C / M S t R=4.93 \min ($ Characterization Method $A) ; m / z=402.70(M+H) ; 1 H$ NMR $(300 \mathrm{MHz}, \mathrm{CD} 30 D) \delta=$ $8.00(\mathrm{t}, \mathrm{J}=1.9 \mathrm{~Hz}, 1 \mathrm{H}), 7.65(\mathrm{dd}, \mathrm{J}=0.7,7.9 \mathrm{~Hz}, 1 \mathrm{H}), 7.52-7.24(\mathrm{~m}, 6 \mathrm{H}), 3.33(\mathrm{q}, \mathrm{J}=1.0 \mathrm{~Hz}, 2 \mathrm{H})$.

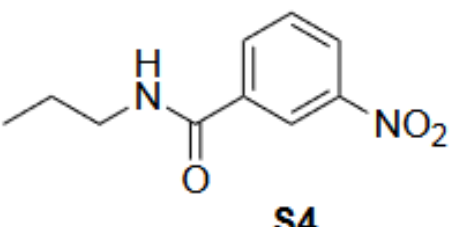

\section{3-nitro-N-propylbenzamide (S4)}

To an oven-dried round bottom flask with stir bar under nitrogen were added 3-nitrobenzoic acid (1 g, 5.98 $\mathrm{mmol}$ ), dry DCM, and $3 \AA ̊$ molecular sieves. Oxalyl chloride (1.2 eq.) and a catalytic amount of DMF (1 mol \%) were added and the reaction was stirred while attached to a bubbler (to monitor production of $\mathrm{CO} 2$ ) at $20^{\circ} \mathrm{C}$ for $2 \mathrm{~h}$. propylamine (1 eq.) in DCM and DIPEA (2 eq.) were added and the reaction was stirred under nitrogen for $23 \mathrm{~h}$. The reaction was diluted with EtOAc and washed with half-saturated aqueous $\mathrm{NaHCO}, 1 \mathrm{M} \mathrm{HCl}(30 \mathrm{~mL})$, brine, dried over $\mathrm{Na} 2 \mathrm{SO} 4$, filtered, and concentrated under reduced pressure to give $\mathrm{S} 4(1 \mathrm{~g})$ as a beige solid in $83 \%$ yield. The material was pushed forward without purification. LC/MS tR $=6.88 \mathrm{~min}$ (Characterization Method A); $\mathrm{m} / \mathrm{z}=209.70(\mathrm{M}+\mathrm{H}) ; 1 \mathrm{H} \mathrm{NMR}(400 \mathrm{MHz}, \mathrm{CDCl}) \quad \delta=8.55(\mathrm{t}, \mathrm{J}=1.9 \mathrm{~Hz}, 1 \mathrm{H}), 8.21-8.15(\mathrm{~m}, 1 \mathrm{H}), 8.12(\mathrm{td}, \mathrm{J}=$ $1.2,7.8 \mathrm{~Hz}, 1 \mathrm{H}), 7.77(\mathrm{t}, \mathrm{J}=5.4 \mathrm{~Hz}, 1 \mathrm{H}), 7.49(\mathrm{t}, \mathrm{J}=8.0 \mathrm{~Hz}, 1 \mathrm{H}), 3.39-3.28(\mathrm{~m}, 2 \mathrm{H}), 1.57(\mathrm{sxt}, \mathrm{J}=7.3 \mathrm{~Hz}, 2 \mathrm{H})$, $0.86(t, J=7.4 \mathrm{~Hz}, 3 \mathrm{H})$.<smiles>CCCNC(=O)c1cccc(N)c1</smiles>

\section{3-amino-N-propylbenzamide (S5)}

A solution of S4 $(940 \mathrm{mg}, 4.51 \mathrm{mmol})$ in $\mathrm{EtOH}(20 \mathrm{~mL})$ was flushed with nitrogen for $5 \mathrm{~min}$. To a $250 \mathrm{~mL}$ round bottom hydrogenator flask under nitrogen was suspended $10 \% \mathrm{Pd} / \mathrm{C}(240 \mathrm{mg}, 0.226 \mathrm{mmol})$ in EtOH/H2O $(4: 1)$ and the resultant suspension was added to the solution of S4. The flask was attached to the hydrogenator and the reaction was purged with $\mathrm{H} 2$ gas for $2 \mathrm{~min}$. The reaction was left to stir at room temperature under 25 bar of $\mathrm{H} 2$ for $1 \mathrm{~h}$, after which an aliquot was taken from the reaction, filtered through celite and cotton, and concentrated under reduced pressure. The aliquot was used for LCMS monitoring which showed reaction completion. The reaction was filtered through a funnel packed with Celite. The filter cake was washed with $\mathrm{MeOH}$ and the filtrate was concentrated under reduced pressure. The free-amine was dissolved in DCM and added to $0.6 \mathrm{M} \mathrm{HCl}$ in ether $(20 \mathrm{~mL})$ to give $\mathrm{S} 5(900 \mathrm{mg})$ as a clear yellow oil in $93 \%$ yield. The material was pushed forward without purification. $L C / M S t R=3.84 \mathrm{~min}$ (Characterization Method $A) ; \mathrm{m} / \mathrm{z}=178.85(\mathrm{M}+\mathrm{H}$ ); 13C NMR (75 MHz, CD3OD) $\delta=166.8,136.6,131.3,130.1,127.0,125.6,122.0,41.5,22.3,10.4$. 


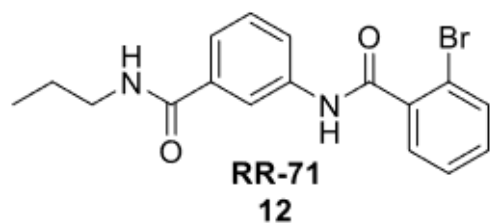

\section{3-(2-bromobenzamido)-N-propylbenzamide (12)}

Analogue (9) was synthesized by acylating S5 with 2-bromobenzoyl chloride ( $53 \mu \mathrm{L}, 0.408 \mathrm{mmol}$ ) according to general method C. The crude material was dissolved in a minimal amount of DCM, loaded onto a $25 \mathrm{~g}$ silica column, and purified by flash chromatography (EtOAc:hexanes, $0-50 \%$ ) to give 12 as a white solid (26 mg) in $23 \%$ yield. $\mathrm{LC} / \mathrm{MS} \mathrm{tR}=5.41 \mathrm{~min}$ (Characterization Method $\mathrm{A}) ; \mathrm{m} / \mathrm{z}=384.80(\mathrm{M}+\mathrm{Na}) ; 1 \mathrm{H} \mathrm{NMR}(400 \mathrm{MHz}, \mathrm{CD} 3 \mathrm{OD})$ $\delta=8.11(\mathrm{~s}, 1 \mathrm{H}), 7.83(\mathrm{~d}, \mathrm{~J}=8.0 \mathrm{~Hz}, 1 \mathrm{H}), 7.69(\mathrm{~d}, \mathrm{~J}=8.0 \mathrm{~Hz}, 1 \mathrm{H}), 7.61-7.50(\mathrm{~m}, 2 \mathrm{H}), 7.50-7.36(\mathrm{~m}, 3 \mathrm{H}), 3.34(\mathrm{t}$, $\mathrm{J}=7.3 \mathrm{~Hz}, 2 \mathrm{H}), 1.64(\mathrm{sxt}, \mathrm{J}=7.2 \mathrm{~Hz}, 2 \mathrm{H}), 0.98(\mathrm{t}, \mathrm{J}=7.3 \mathrm{~Hz}, 3 \mathrm{H})$.

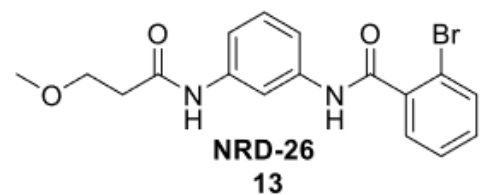

2-bromo-N-[3-(3-methoxypropanamido)phenyl]benzamide (13)

Analogue (13) was synthesized by coupling S3 with 3-methoxypropanoic acid (16 $\mu \mathrm{L}, 0.174 \mathrm{mmol}$ ) according to general method $A$. The crude material was dissolved in a minimal amount of $D C M$, loaded onto a $5 \mathrm{~g}$ silica column, and purified by flash chromatography (EtOAc:hexanes, $0-50 \%$ ) to give 13 as a white solid (26 mg) in $40 \%$ yield. $L C / M S$ tR $=4.36$ min (Characterization Method $\mathrm{A}) ; \mathrm{m} / \mathrm{z}=478.70(\mathrm{M}+\mathrm{H}) ; 1 \mathrm{H} \mathrm{NMR}(300 \mathrm{MHz}, \mathrm{CD} 3 \mathrm{OD})$ $\delta=7.99(\mathrm{t}, \mathrm{J}=1.9 \mathrm{~Hz}, 1 \mathrm{H}), 7.67(\mathrm{dd}, \mathrm{J}=0.9,8.0 \mathrm{~Hz}, 1 \mathrm{H}), 7.54-7.42(\mathrm{~m}, 2 \mathrm{H}), 7.42-7.34(\mathrm{~m}, 3 \mathrm{H}), 7.29(\mathrm{q}, \mathrm{J}=1.0$ $\mathrm{Hz}, 1 \mathrm{H}), 3.71(\mathrm{t}, \mathrm{J}=6.1 \mathrm{~Hz}, 2 \mathrm{H}), 3.35(\mathrm{~s}, 3 \mathrm{H}), 2.61(\mathrm{t}, \mathrm{J}=6.1 \mathrm{~Hz}, 2 \mathrm{H})$.

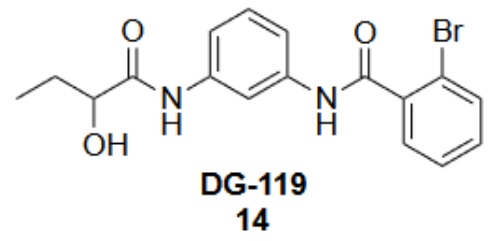

\section{2-bromo-N-[3-(2-hydroxybutanamido)phenyl]benzamide (14)}

To an oven-dried round bottom flask with stir bar under nitrogen were added [(2S)-2-

hydroxybutanoyl]oxysodium (50 mg, $0.40 \mathrm{mmol})$, PyBOP $(210 \mathrm{mg}, 0.40 \mathrm{mmol})$, and anhydrous DCE $(4.0 \mathrm{~mL})$. The resulting solution was stirred for $10 \mathrm{~min}$ at room temperature before aniline S3 (100 $\mathrm{mg}, 0.34 \mathrm{mmol}$ ) and DIPEA $(60 \mu \mathrm{L}, 0.35 \mathrm{mmol})$ were added. The reaction was heated at $45 \stackrel{\circ}{\mathrm{C}}$ for $48 \mathrm{~h}$. After $48 \mathrm{~h}$, a small aliquot was taken from the reaction, concentrated under reduced pressure, dissolved in minimal amount of HPLC grade MeCN, and analyzed with LCMS to confirm reaction completion. The reaction was diluted with DCM (10 mL), washed with saturated aqueous $\mathrm{NaHCO} 3$, brine, dried over $\mathrm{Na} 2 \mathrm{SO} 4$, filtered, and concentrated under vacuum to give crude material which dissolved in minimal DCM, loaded on to a $10 \mathrm{~g}$ silica column, and purified by flash chromatography (EtOAc:hexanes $0-100 \%$ ) to give $25 \mathrm{mg}$ of 14 in $19 \%$ yield. LC/MS tR $=5.54 \mathrm{~min}$ (Characterization Method A); $\mathrm{m} / \mathrm{z}=400.75(\mathrm{M}+\mathrm{Na}) ; 1 \mathrm{H} \mathrm{NMR}(300 \mathrm{MHz}, \mathrm{CD} 3 \mathrm{OD}) \delta=7.95(\mathrm{t}, \mathrm{J}=2.1 \mathrm{~Hz}, 1 \mathrm{H}), 7.66$ (dd, J = 8.0, 1.1 Hz, 1H), 7.53-7.42 (m, 4H), 7.39-7.28 (m, 2H), $4.09(\mathrm{dd}, \mathrm{J}=7.3,4.2 \mathrm{~Hz}, 1 \mathrm{H}), 1.92-1.84(\mathrm{~m}, 1 \mathrm{H})$, 1.79-1.65 (m, $1 \mathrm{H}), 1.01(\mathrm{t}, \mathrm{J}=7.4 \mathrm{~Hz}, 3 \mathrm{H})$. 


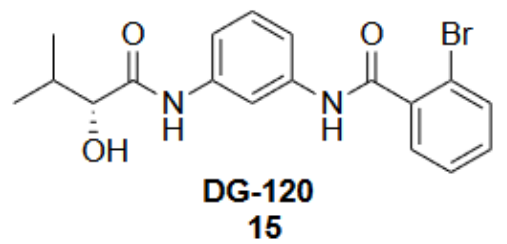

2-bromo-N-\{3-[(2R)-2-hydroxy-3-methylbutanamido]phenyl\}benzamide

To an oven-dried round bottom flask with stir bar under nitrogen were added [(2R)-2-hydroxy-3-methylbutanoic acid ( $39 \mathrm{mg}, 0.33 \mathrm{mmol}$ ), PyBOP (160 mg, $0.31 \mathrm{mmol}$ ), and anhydrous DCE $(3.0 \mathrm{~mL})$. The resulting solution was stirred for $10 \mathrm{~min}$ at room temperature before aniline $\mathrm{S} 3(75.0 \mathrm{mg}, 0.34 \mathrm{mmol})$ and DIPEA (50 $\mu \mathrm{L}$, $0.29 \mathrm{mmol}$ ) were added. The reaction was heated at 45 으 for $48 \mathrm{~h}$. After $48 \mathrm{~h}$, a small aliquot was taken from the reaction, concentrated under reduced pressure, dissolved in minimal amount of HPLC grade MeCN, and analyzed with LCMS to confirm reaction completion. The reaction was diluted with DCM $(10 \mathrm{~mL})$, washed with saturated aqueous $\mathrm{NaHCO} 3$, brine, dried over $\mathrm{Na} 2 \mathrm{SO} 4$, filtered, and concentrated under vacuum to afford crude material which was purified using preparative HPLC (MeOH:H2O with $0.1 \%$ formic acid, $50-95 \%)$ to give $8 \mathrm{mg}$ of 15 in $8 \%$ yield. $L C / M S t R=5.43$ min (Characterization Method A); $m / z=414.75(\mathrm{M}+\mathrm{Na}) ; 1 \mathrm{H} \mathrm{NMR}(300 \mathrm{MHz}$, CD3OD) $\delta=8.99$ (br. s., $1 \mathrm{H}), 7.92-7.88(\mathrm{~m}, 1 \mathrm{H}), 7.69-7.30(\mathrm{~m}, 8 \mathrm{H}), 4.05-4.02(\mathrm{~m}, 1 \mathrm{H}), 3.47-3.38(\mathrm{~m}, 1 \mathrm{H}), 2.27-$ $2.19(\mathrm{~m}, 1 \mathrm{H}), 1.09-1.05(\mathrm{~m}, 3 \mathrm{H}), 0.93-0.89(\mathrm{~m}, 3 \mathrm{H})$.<smiles>CC(C)C(O)C(=O)Nc1cccc(NC(=O)c2ccccc2Br)c1</smiles>

\section{2-bromo-N-\{3-[(2S)-2-hydroxy-3-methylbutanamido]phenyl\}benzamide}

To an oven-dried round bottom flask with stir bar under nitrogen were added [(2S)-2-hydroxy-3-methyl-butanoic acid (39 mg, $0.33 \mathrm{mmol})$, PyBOP (160 mg, $0.31 \mathrm{mmol})$, and anhydrous DCE $(3.0 \mathrm{~mL})$. The resulting solution was stirred for $10 \mathrm{~min}$ at room temperature before aniline $\mathrm{S} 3(75.0 \mathrm{mg}, 0.34 \mathrm{mmol})$ and DIPEA (50 $\mu \mathrm{L}, 0.29 \mathrm{mmol})$ were added. The reaction was heated at $45 \circ \mathrm{C}$ for $48 \mathrm{~h}$. After $48 \mathrm{~h}$, a small aliquot was taken from the reaction, concentrated under reduced pressure, dissolved in minimal amount of HPLC grade MeCN, and analyzed with LCMS to confirm reaction completion. The reaction was diluted with DCM $(10 \mathrm{~mL})$, washed with saturated aqueous $\mathrm{NaHCO} 3$, brine, dried over $\mathrm{Na2SO} 4$, filtered, and concentrated under vacuum to afford crude material which was purified using preparative HPLC (MeOH: $\mathrm{H} 2 \mathrm{O}$ with $0.1 \%$ formic acid, 50-95\%) to give $9 \mathrm{mg}$ of 16 in $9 \%$ yield. $\mathrm{LC} / \mathrm{MS} \mathrm{tR}=5.44 \mathrm{~min}$ (Characterization Method A); $\mathrm{m} / \mathrm{z}=414.75(\mathrm{M}+\mathrm{Na}) ; 1 \mathrm{H} \mathrm{NMR}(300 \mathrm{MHz}, \mathrm{CD} 3 \mathrm{OD}) \delta=$ $7.97(\mathrm{t}, \mathrm{J}=2.0 \mathrm{~Hz}, 1 \mathrm{H}), 7.67(\mathrm{dd}, \mathrm{J}=8.0,1.1 \mathrm{~Hz}, 1 \mathrm{H}), 7.54-7.29(\mathrm{~m}, 6 \mathrm{H}), 3.97(\mathrm{~d}, \mathrm{~J}=3.8 \mathrm{~Hz}, 1 \mathrm{H}), 2.22-2.12(\mathrm{~m}, 1 \mathrm{H})$, $1.05(\mathrm{~d}, \mathrm{~J}=6.9 \mathrm{~Hz}, 3 \mathrm{H}), 0.92(\mathrm{~d}, \mathrm{~J}=6.8 \mathrm{~Hz}, 3 \mathrm{H})$.<smiles>COCC(=O)Nc1cccc(NC(=O)c2ccccc2Br)c1</smiles>

2-bromo-N-[3-(2-methoxyacetamido)phenyl]benzamide (17)

Analogue (17) was synthesized via a peptide coupling between $\mathrm{S} 3(50.0 \mathrm{mg}, 0.172 \mathrm{mmol})$ and methoxyacetic acid $(23.2 \mathrm{mg}, 0.258 \mathrm{mmol}$ ) according to general method $A$. The crude material was dissolved in a minimal amount of DCM, loaded onto a $10 \mathrm{~g}$ silica column, and purified by flash chromatography (MeOH:DCM, 0-10\%) to give 17 as a yellow oil $(46 \mathrm{mg})$ in $73 \%$ yield. $L C / M S ~ t R=4.39 \mathrm{~min}$ (Characterization Method A); $\mathrm{m} / \mathrm{z}=362.70(\mathrm{M}+$ $\mathrm{H}) ; 1 \mathrm{H} \mathrm{NMR}(300 \mathrm{MHz}, \mathrm{CDCl} 3) \delta 8.00(\mathrm{t}, \mathrm{J}=1.9 \mathrm{~Hz}, 1 \mathrm{H}), 7.68(\mathrm{dd}, \mathrm{J}=7.9,0.9 \mathrm{~Hz}, 1 \mathrm{H}), 7.54-7.29(\mathrm{~m}, 7 \mathrm{H}), 4.04(\mathrm{~s}$, $2 \mathrm{H}), 3.48(\mathrm{~s}, 3 \mathrm{H})$. 
<smiles>[R20][R6]</smiles>

2-bromo-N-[3-(2-methoxypropanamido)phenyl]benzamide (18)

Analogue (18) was synthesized by acylating S3 with 2-methoxypropanoyl chloride ( $35.0 \mathrm{mg}, 0.286 \mathrm{mmol}$ ) according to general method $\mathrm{C}$. The crude material was dissolved in a minimal amount of DCM, loaded onto a 10 g silica column, and purified by flash chromatography (EtOAc:hexanes, 0-60\%) to give 18 as a white solid (36 $\mathrm{mg}$ ) in 33\% yield. $\mathrm{LC} / \mathrm{MS} \mathrm{tR}=5.20 \mathrm{~min}$ (Characterization Method A); $\mathrm{m} / \mathrm{z}=400.75(\mathrm{M}+\mathrm{Na}) ; 1 \mathrm{H} \mathrm{NMR}(400 \mathrm{MHz}$, $\mathrm{CDCl} 3) \delta=8.43$ (br. s, $1 \mathrm{H}$ ), 8.04 (br. s, $1 \mathrm{H}$ ), $7.99(\mathrm{t}, \mathrm{J}=2.0 \mathrm{~Hz}, 1 \mathrm{H}), 7.61$ (dd, J = 1.1, 7.9 Hz, $1 \mathrm{H}), 7.57$ (dd, J = 1.8, $7.6 \mathrm{~Hz}, 1 \mathrm{H}), 7.47-7.40(\mathrm{~m}, 2 \mathrm{H}), 7.38(\mathrm{dt}, \mathrm{J}=1.2,7.5 \mathrm{~Hz}, 1 \mathrm{H}), 7.34-7.27(\mathrm{~m}, 2 \mathrm{H}), 3.79(\mathrm{q}, \mathrm{J}=6.8 \mathrm{~Hz}, 1 \mathrm{H}), 3.46$ $(\mathrm{s}, 3 \mathrm{H}), 1.42(\mathrm{~d}, \mathrm{~J}=6.8 \mathrm{~Hz}, 3 \mathrm{H})$.<smiles>COC(=O)CC(=O)Nc1cccc(NC(=O)c2ccccc2Br)c1</smiles>

methyl 2-\{[3-(2-bromobenzamido)phenyl]carbamoyl\}acetate (19) Analogue (19) was synthesized by acylating S3 with methyl 3-chloro-3-oxo-propanoate (120 $\mu \mathrm{L}, 1.12$ mmol)according to general method $\mathrm{C}$. The crude material was dissolved in a minimal amount of DCM, loaded onto a $10 \mathrm{~g}$ silica column, and purified by flash chromatography (EtOAc:hexanes, 0-80\%) to give 19as a pale yellow solid(100 mg) in 26\% yield.1H NMR (300MHz,CDCl3) $\delta=9.30(\mathrm{~s}, 1 \mathrm{H}), 8.38(\mathrm{~s}, 1 \mathrm{H}), 7.87(\mathrm{~s}, 1 \mathrm{H}), 7.59-7.43$ (m, $3 \mathrm{H}), 7.35-7.26(\mathrm{~m}, 2 \mathrm{H}), 7.24-7.19(\mathrm{~m}, 1 \mathrm{H}), 3.71(\mathrm{~s}, 3 \mathrm{H}), 3.36(\mathrm{~s}, 2 \mathrm{H})$.<smiles>O=C(O)CC(=O)Nc1cccc(NC(=O)c2ccccc2Br)c1</smiles>

\section{2-\{[3-(2-bromobenzamido)phenyl]carbamoyl\}acetic acid (20)}

To a $25 \mathrm{~mL}$ round bottom flask with a stir bar was added $19(23.0 \mathrm{mg}, 0.0588 \mathrm{mmol})$ and THF $(4 \mathrm{~mL})$ and H2O (2 $\mathrm{mL}$ ). LiOH ( $3 \mathrm{mg}, 0.134 \mathrm{mmol}$ ) was added and the reaction was stirred for $1 \mathrm{~h}$ at room temperature. The reaction was diluted with EtOAc $(15 \mathrm{~mL})$ and washed with $1 \mathrm{M} \mathrm{HCl}(15 \mathrm{~mL})$. The layers were separated, and a second extraction was performed on the aqueous layer with EtOAc (15 mL). The organic layers were combined and washed with brine $(2 \mathrm{X} 10 \mathrm{~mL})$, dried over with $\mathrm{NaSO} 4$, filtered, and concentrated under reduced pressure to give the desired product 20 as a light brown solid $(20 \mathrm{mg})$ in $90 \%$ yield. $1 \mathrm{H}$ NMR (300 MHz, CD3OD) $\delta=8.01$ (d, J = 1.3 $\mathrm{Hz}, 1 \mathrm{H}), 7.68(\mathrm{~d}, \mathrm{~J}=8.0 \mathrm{~Hz}, 1 \mathrm{H}), 7.56-7.44(\mathrm{~m}, 2 \mathrm{H}), 7.44-7.37(\mathrm{~m}, 3 \mathrm{H}), 7.36-7.25(\mathrm{~m}, 1 \mathrm{H}), 3.46(\mathrm{~s}, 2 \mathrm{H})$.<smiles>NC(=O)CC(=O)Nc1cccc(NC(=O)c2ccccc2Br)c1</smiles>

\section{N'-[3-(2-bromobenzamido)phenyl]propanediamide (21)}

To a $20 \mathrm{~mL}$ scintillation vial with a stir bar was added $19(25.0 \mathrm{mg}, 0.0639 \mathrm{mmol})$ and via syringe was added THF $(0.5 \mathrm{~mL})$ and $7 \mathrm{~N} \mathrm{NH} 4 \mathrm{OH}(1 \mathrm{~mL})$, respectively. The reaction solvent was removed under reduced pressure to give the crude product. The product was dissolved in a minimal amount of DMSO, and loaded onto a $12 \mathrm{~g}$ C18 column, and purified via reverse phase chromatography (MeOH:water, $0-100 \%)$ to give product 21 as a white 
crystalline solid $(10 \mathrm{mg})$ in $42 \%$ yield. $1 \mathrm{H} \mathrm{NMR}(300 \mathrm{MHz}, \mathrm{CD} 3 \mathrm{OD}) \delta=8.02-7.96(\mathrm{~m}, 1 \mathrm{H}), 7.67(\mathrm{dd}, \mathrm{J}=1.1,8.0$ $\mathrm{Hz}, 1 \mathrm{H}), 7.54$ - 7.45 (m, $2 \mathrm{H}), 7.44-7.36(\mathrm{~m}, 3 \mathrm{H}), 7.35$ - $7.25(\mathrm{~m}, 1 \mathrm{H}), 3.37(\mathrm{~s}, 2 \mathrm{H})$.<smiles>COC(=O)Nc1cccc(NC(=O)c2ccccc2Br)c1</smiles>

VAK-9

22

methyl N-[3-(2-bromobenzamido)phenyl]carbamate (22)

To an oven-dried round bottom flask with stir bar under nitrogen were added aniline $\mathrm{S} 3$ ( $50 \mathrm{mg}, 0.172 \mathrm{mmol}$ ), anhydrous DCE, and TEA $(23.9 \mu \mathrm{L}, 0.172 \mathrm{mmol})$. The vessel was flushed with nitrogen gas for an additional $5 \mathrm{~min}$ and then methyl chloroformate $(13 \mu \mathrm{L}, 0.172 \mathrm{mmol})$ was added and the reaction was allowed to stir at room temperature for $48 \mathrm{~h}$. A sample aliquot was taken from the reaction, concentrated under reduced pressure, dissolved in a minimal amount of HPLC grade MeCN, and analyzed with LCMS to confirm reaction completion. The reaction was diluted with EtOAc and washed with half-saturated aqueous $\mathrm{NaHCO}, 1 \mathrm{M} \mathrm{HCl}(30 \mathrm{~mL})$, brine, dried over $\mathrm{Na}_{2} \mathrm{SO} 4$, filtered, and concentrated under reduced pressure to give crude material which was dissolved in a minimal amount of DCM, loaded onto a $10 \mathrm{~g}$ silica column, and purified by flash chromatography ( $\mathrm{MeOH}: D C M, 0-4 \%)$ to give 22 as a colorless oil $(15 \mathrm{mg})$ in $25 \%$ yield. $\mathrm{LC} / \mathrm{MS} \mathrm{tR}=4.70 \mathrm{~min}$ (Characterization Method A); $\mathrm{m} / \mathrm{z}=350.65(\mathrm{M}+\mathrm{H}) .1 \mathrm{H} \mathrm{NMR}(400 \mathrm{MHz}, \mathrm{CD} 3 \mathrm{OD}) \delta 7.87-7.85(\mathrm{~m}, 1 \mathrm{H}), 7.68(\mathrm{ddd}, \mathrm{J}=8.0,1.2,0.4 \mathrm{~Hz}$, $1 \mathrm{H}$ ), 7.52 (ddd, J = 7.6, 1.9, 0.4 Hz, 1H), 7.47 (td, J = 7.5, 1.2 Hz, 1H), 7.38 (ddd, J = 8.0, 7.3, 1.9 Hz, 1H), 7.33-7.25 $(\mathrm{m}, 3 \mathrm{H}), 3.74(\mathrm{~s}, 3 \mathrm{H})$.

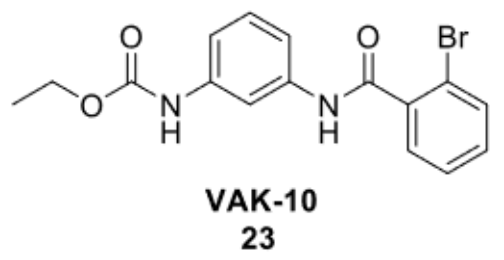

ethyl N-[3-(2-bromobenzamido)phenyl]carbamate (23)

To an oven-dried round bottom flask with stir bar under nitrogen were added aniline S3 (50 mg, $0.172 \mathrm{mmol}$ ), anhydrous DCE, and TEA ( $23.9 \mu \mathrm{L}, 0.172 \mathrm{mmol})$. The vessel was flushed with nitrogen gas for an additional $5 \mathrm{~min}$ and then ethyl chloroformate $(16 \mu \mathrm{L}, 0.172 \mathrm{mmol})$ was

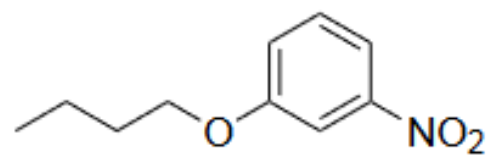

S6

\section{1-butoxy-3-nitrobenzene (S6)}

To a round bottom flask with stir bar under nitrogen were added 3-nitrophenol (500 mg, $3.59 \mathrm{mmol}), 60 \% \mathrm{NaH}$ in mineral oil ( $0.154 \mathrm{~mL}, 5.39 \mathrm{mmol})$, and DMF $(6 \mathrm{~mL})$. The flask was flushed with nitrogen for an additional 5 min and 1-bromobutane $(0.466 \mathrm{~mL}, 4.31 \mathrm{mmol})$ was syringed into the vessel. The reaction was stirred under nitrogen overnight at $125^{\circ} \mathrm{C}$. A small aliquot of the reaction was taken and monitored via TLC which showed consumption of starting material and formation of desired product. The reaction was diluted with $\mathrm{EtOAc}(30 \mathrm{~mL})$ and transferred to a $500 \mathrm{~mL}$ separatory funnel. The organic layer was washed with water $(3 \times 20 \mathrm{~mL})$ and then collected in an Erlenmeyer flask and dried with sodium sulfate. The dry organic solvent was transferred to a preweighed round bottom flask, concentrated down on the rotovap and placed on the hi-vac overnight to give S6 $(692 \mathrm{mg}$ ) as a clear oil in $99 \%$ yield. The material was pushed forward without purification. This compound has been previously reported and characterized (CAS\#122329-01-5). TLC: mobile phase: EtOAc:hexanes (25:75), Rf: 
0.9; $1 \mathrm{H} \mathrm{NMR} \mathrm{(400} \mathrm{MHz,} \mathrm{CDCl3)} \delta=7.80(\mathrm{td}, \mathrm{J}=0.9,8.2 \mathrm{~Hz}, 1 \mathrm{H}), 7.71(\mathrm{t}, \mathrm{J}=1.0 \mathrm{~Hz}, 1 \mathrm{H}), 7.41(\mathrm{t}, \mathrm{J}=8.2 \mathrm{~Hz}, 1 \mathrm{H})$, $7.21(\mathrm{td}, \mathrm{J}=1.0,8.2 \mathrm{~Hz}, 1 \mathrm{H}), 4.04(\mathrm{t}, \mathrm{J}=1.0 \mathrm{~Hz}, 2 \mathrm{H}), 1.85-1.76(\mathrm{~m}, 2 \mathrm{H}), 1.57-1.46(\mathrm{~m}, 2 \mathrm{H}), 0.99(\mathrm{t}, \mathrm{J}=7.4 \mathrm{~Hz}, 3$ H).

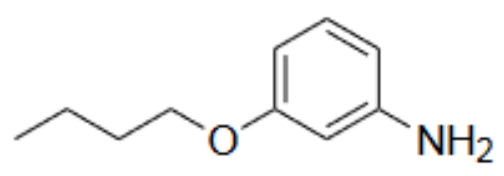

S7

\section{3-butoxyaniline (S7)}

A solution of $\mathrm{S} 6(692 \mathrm{mg}, 3.54 \mathrm{mmol})$ in $\mathrm{MeOH}(5 \mathrm{~mL})$ was flushed with nitrogen for $5 \mathrm{~min}$. To a $50 \mathrm{~mL}$ round bottom flask under nitrogen was suspended 10\% Pd/C (197 mg, $3.54 \mathrm{mmol}$ ) in $\mathrm{MeOH} / \mathrm{H} 2 \mathrm{O}(4: 1)$ and the resultant suspension was added to the solution of $\mathrm{S} 6$. A balloon was filled with $\mathrm{H} 2$ gas and inserted into the flask and the reaction was purged with $\mathrm{H} 2$ gas for $2 \mathrm{~min}$. The reaction was left to stir under a full balloon of $\mathrm{H} 2$ for $1 \mathrm{~h}$, after which an aliquot was taken from the reaction, filtered through celite and cotton, and concentrated under reduced pressure. The aliquot was used for TLC monitoring which showed reaction completion. The reaction was filtered through a funnel packed with Celite. The filter cake was washed with $\mathrm{MeOH}$ and the filtrate was concentrated under reduced pressure, to give $S 7(553 \mathrm{mg})$ as a dark yellow oil in $94 \%$ yield. The material was pushed forward without purification. This compound has been previously reported and characterized (CAS\#23079-68-7). TLC: mobile phase: EtOAc:hexanes (25:75), Rf: 0.55; $1 \mathrm{H} \mathrm{NMR}(300 \mathrm{MHz}, \mathrm{CDCl} 3) \delta=7.04$ (t, J = $8.0 \mathrm{~Hz}, 1 \mathrm{H}), 6.38-6.21(\mathrm{~m}, 3 \mathrm{H}), 3.91(\mathrm{t}, \mathrm{J}=6.5 \mathrm{~Hz}, 2 \mathrm{H}), 1.80-1.67(\mathrm{~m}, 2 \mathrm{H}), 1.47(\mathrm{~m}, 2 \mathrm{H}), 0.96(\mathrm{t}, \mathrm{J}=7.4 \mathrm{~Hz}, 3$ $\mathrm{H})$.filled with $\mathrm{H} 2$ gas and inserted into the flask and the reaction was purged with $\mathrm{H} 2$ gas for 2 min. The reaction was left to stir under a full balloon of $\mathrm{H} 2$ for $1 \mathrm{~h}$, after which an aliquot was taken from the reaction, filtered through celite and cotton, and concentrated under reduced pressure. The aliquot was used for TLC monitoring which showed reaction completion. The reaction was filtered through a funnel packed with Celite. The filter cake was washed with $\mathrm{MeOH}$ and the filtrate was concentrated under reduced pressure, to give $\mathrm{S} 7$ (553 $\mathrm{mg}$ ) as a dark yellow oil in $94 \%$ yield. The material was pushed forward without purification. This compound has been previously reported and characterized (CAS\#23079-68-7). TLC: mobile phase: EtOAc:hexanes (25:75), Rf: 0.55; $1 \mathrm{H} \mathrm{NMR}(300 \mathrm{MHz}, \mathrm{CDCl} 3) \delta=7.04(\mathrm{t}, \mathrm{J}=8.0 \mathrm{~Hz}, 1 \mathrm{H}), 6.38-6.21(\mathrm{~m}, 3 \mathrm{H}), 3.91(\mathrm{t}, \mathrm{J}=6.5 \mathrm{~Hz}, 2 \mathrm{H}), 1.80-1.67(\mathrm{~m}$, $2 \mathrm{H}), 1.47(\mathrm{~m}, 2 \mathrm{H}), 0.96(\mathrm{t}, \mathrm{J}=7.4 \mathrm{~Hz}, 3 \mathrm{H})$.

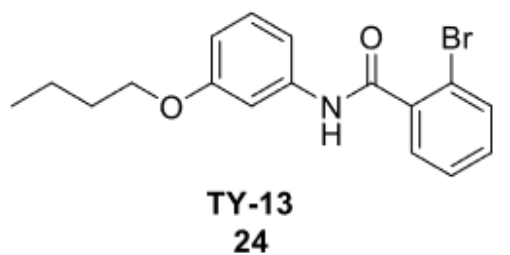

2-bromo-N-(3-butoxyphenyl)benzamide (24)

Analogue (24) was synthesized by coupling S7 with 2-bromobenzoyl chloride (956 mg, $4.35 \mathrm{mmol}$ ) according to general method $\mathrm{C}$. The crude material was dissolved in a minimal amount of DCM, loaded onto a $50 \mathrm{~g}$ silica column, and purified by flash chromatography (EtOAc:hexanes, 0-30\%) to give 24 as a white solid (138 $\mathrm{mg}$ ) in $12 \%$ yield. $1 \mathrm{H} \mathrm{NMR}(400 \mathrm{MHz}, \mathrm{CDCl} 3) \delta=7.69-7.63(\mathrm{~m}, 2 \mathrm{H}), 7.62$ (br. s., $1 \mathrm{H}), 7.46-7.38(\mathrm{~m}, 2 \mathrm{H}), 7.37-7.30$ $(\mathrm{m}, 1 \mathrm{H}), 7.26-7.22(\mathrm{~m}, 1 \mathrm{H}), 7.10-7.04(\mathrm{~m}, 1 \mathrm{H}), 6.75-6.70(\mathrm{~m}, 1 \mathrm{H}), 4.00(\mathrm{t}, \mathrm{J}=6.5 \mathrm{~Hz}, 2 \mathrm{H}), 1.83-1.73(\mathrm{~m}, 2$ H), $1.54-1.45(m, 2 \mathrm{H}), 0.98(\mathrm{t}, \mathrm{J}=7.4 \mathrm{~Hz}, 3 \mathrm{H})$. 


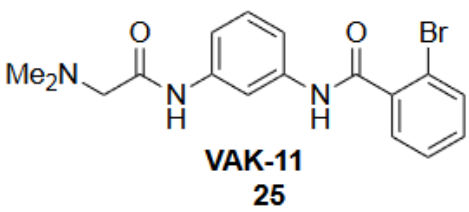

2-bromo-N-\{3-[2-dimethylamino)acetamido]phenyl\}benzamide (25)

Analogue (25) was synthesized via a peptide coupling between S3 (50.0 mg, $0.172 \mathrm{mmol})$, and 2-

(dimethylamino)acetic acid $(26.6 \mathrm{mg}, 0.252 \mathrm{mmol})$ according to general method $A$. The crude material was dissolved in minimal DCM, loaded on to a $25 \mathrm{~g}$ silica column, and purified by flash chromatography (EtOAc:hexanes $0-100 \%$ ) to give 25 as an off white solid in $44 \%$ yield. LC/MS tR $=1.68 \mathrm{~min}$ (Characterization Method A); $\mathrm{m} / \mathrm{z}=377.75(\mathrm{M}+\mathrm{H}) ; 1 \mathrm{H} \mathrm{NMR}(300 \mathrm{MHz}, \mathrm{CDCl} 3) \delta 7.99(\mathrm{t}, \mathrm{J}=1.9 \mathrm{~Hz}, 1 \mathrm{H}), 7.68(\mathrm{dd}, \mathrm{J}=7.9,0.9 \mathrm{~Hz}$, $1 \mathrm{H}), 7.54-7.28(\mathrm{~m}, 7 \mathrm{H}), 3.14(\mathrm{~s}, 2 \mathrm{H}), 2.38(\mathrm{~s}, 6 \mathrm{H})$.<smiles>CCCN(CC)c1cccc(NC(=O)c2ccccc2Br)c1</smiles>

26

2-bromo-N-[3-(dipropylamino)phenyl]benzamide (26)

To a $50 \mathrm{~mL}$ round bottom flask was added a magnetic stir bar and $40 \mathrm{mg}$ of 3 A molecular sieves. Propanal (352 $\mu \mathrm{L}, 4.91 \mathrm{mmol}$ ) was added to the round bottom flask alongside methanol $(4 \mathrm{~mL})$ and Acetic acid $(14.1 \mu \mathrm{L}, 0.246$ $\mathrm{mmol}$ ). The vessel was sealed and flushed with nitrogen gas for 2 min and to this S3 was added into the flask. The mixture was cooled to $0^{\circ} \mathrm{C}$ and allowed to stir for $30 \mathrm{~min}$ before $\mathrm{NaBH} 3 \mathrm{CN}(61.7 \mathrm{mg}, 0.982 \mathrm{mmol}$ ) was added. The reaction was allowed to stir at $0^{\circ} \mathrm{C}$ and gradually allowed to warm up to room temperature for an additional $1 \mathrm{~h}$. A sample aliquot was taken from the reaction, diluted with DCM, and washed with half saturated $\mathrm{Na} 2 \mathrm{CO} 3$. The organic layer was separated and analyzed with LCMS to confirm reaction completion. The reaction was diluted with DCM $(10 \mathrm{~mL})$, washed with half-saturated aq. NaHCO3 $(2 \times 15 \mathrm{~mL})$, dried over Na2SO4, filtered, and concentrated under reduced pressure to give crude product. The crude product was dissolved in a minimal amount of DCM, loaded onto a $10 \mathrm{~g}$ silica column, and purified with flash chromatography (MeOH:DCM, 2-10\%) to give amine $26(96 \mathrm{mg})$ as a yellow oil in $59 \%$ yield. $\mathrm{LC} / \mathrm{MS} \mathrm{tR}=5.24 \mathrm{~min}$ (Characterization Method $\mathrm{A}) ; \mathrm{m} / \mathrm{z}=$ $375.90(\mathrm{M}+\mathrm{H})$; $1 \mathrm{H} \mathrm{NMR}(400 \mathrm{MHz}, \mathrm{CDCl}) \delta=7.64-7.55(\mathrm{~m}, 1 \mathrm{H}), 7.42-7.23(\mathrm{~m}, 1 \mathrm{H}), 7.19-7.11(\mathrm{~m}, 1 \mathrm{H}), 6.74$ $(\mathrm{d}, \mathrm{J}=7.8 \mathrm{~Hz}, 0 \mathrm{H}), 6.44(\mathrm{dd}, \mathrm{J}=2.2,8.4 \mathrm{~Hz}, 0 \mathrm{H}), 3.25(\mathrm{t}, \mathrm{J}=1.0 \mathrm{~Hz}, 2 \mathrm{H}), 1.68-1.57(\mathrm{~m}, 2 \mathrm{H}), 0.93(\mathrm{t}, \mathrm{J}=7.4 \mathrm{~Hz}, 3$ H); 13 C NMR (101 MHz, CDCl3) $\delta=165.5,148.9,138.7,138.2,133.4,131.4,129.7,129.6,127.7,119.3,108.3$, 106.7, 103.3, 52.9, 20.4, 11.5.

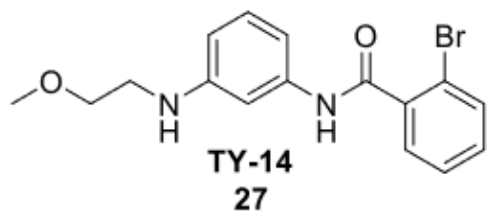

\section{2-bromo-N-\{3-[(2-methoxyethyl)amino]phenyl\}benzamide (27)}

To a $50 \mathrm{~mL}$ round bottom flask was added aniline S3 (50 mg, $0.172 \mathrm{mmol}), \mathrm{K} 2 \mathrm{CO} 3(48 \mathrm{mg}, 0.343 \mathrm{mmol})$, and a magnetic stir bar. The flask was sealed and flushed with nitrogen gas for $5 \mathrm{~min}$. The contents were dissolved in anhydrous DMF ( $5 \mathrm{~mL}$ ) and then 1-bromo-2-methoxyethane $(24 \mu \mathrm{L}, 0.258 \mathrm{mmol})$ was added via syringe to the flask and stirred at $80^{\circ} \mathrm{C}$ for $24 \mathrm{~h}$. After $24 \mathrm{~h}$, the reaction was diluted with EtOAc ( $30 \mathrm{~mL}$ ), washed with halfsaturated aq. $\mathrm{NaHCO} 3(2 \times 15 \mathrm{~mL})$, dried over with $\mathrm{Na2SO} 4$, filtered, and concentrated under reduced pressure to give crude product. The crude product was dissolved in a minimal amount of DCM, loaded onto a $50 \mathrm{~g}$ silica column, and purified with flash chromatography (EtOAc:hexane, $0-65 \%$ ) to give $27(8 \mathrm{mg}$ ) as a yellow oil in $14 \%$ yield. $1 \mathrm{H} \mathrm{NMR}(400 \mathrm{MHz}, \mathrm{CDCl} 3) \delta=7.67-7.62$ (m, $2 \mathrm{H}$ ), 7.54 (br. s., $1 \mathrm{H}$ ), 7.42 (dt, J = 1.2, $7.6 \mathrm{~Hz}, 1 \mathrm{H}$ ), 7.36 - 
$7.28(\mathrm{~m}, 1 \mathrm{H}), 7.22(\mathrm{t}, \mathrm{J}=2.2 \mathrm{~Hz}, 1 \mathrm{H}), 7.16(\mathrm{t}, \mathrm{J}=8.0 \mathrm{~Hz}, 1 \mathrm{H}), 6.76(\mathrm{dd}, \mathrm{J}=1.2,7.8 \mathrm{~Hz}, 1 \mathrm{H}), 6.45(\mathrm{dd}, \mathrm{J}=1.8,7.6$ $\mathrm{Hz}, 1 \mathrm{H}), 3.62(\mathrm{t}, \mathrm{J}=5.1 \mathrm{~Hz}, 2 \mathrm{H}), 3.40(\mathrm{~s}, 3 \mathrm{H}), 3.32(\mathrm{t}, \mathrm{J}=5.3 \mathrm{~Hz}, 2 \mathrm{H})$.<smiles>CCCCOS(=O)(=O)c1cccc(N)c1</smiles>

S8

3-\{[(tert-butyldimethylsilyl)oxy]methyl\}aniline (S8)

3-aminobenzyl alcohol $(1.20 \mathrm{~g}, 9.74 \mathrm{mmol})$ was added to a $100 \mathrm{~mL}$ round bottom flask with a magnetic stir bar, and then dissolved in anhydrous DMF $(25 \mathrm{~mL})$. To the solution was added TBDMSCl $(1.73 \mathrm{~g}, 11.5 \mathrm{mmol})$, DMAP $(0.03 \mathrm{~g}, 0.025 \mathrm{mmol})$, and TEA $(1.63 \mathrm{~mL}, 11.7 \mathrm{mmol})$ and the reaction stir at room temperature for $24 \mathrm{~h}$. A small aliquot of the reaction was taken and used for TLC monitoring, which showed consumption of starting material. The reaction was transferred to a separatory funnel and diluted with DI water and extracted with EtOAc (2x 125 $\mathrm{mL}$ ). The combined organic layers were dried over $\mathrm{Na} 2 \mathrm{SO}$, filtered, and concentrated under reduced pressure to give crude product. The crude material was dissolved in a minimal amount of DCM, loaded onto a $100 \mathrm{~g}$ silica column, and purified by flash chromatography (EtOAc:hexanes, $0-50 \%$ ) to give S8 as a clear liquid (2.1 g) in $91 \%$ yield. This compound has been previously reported and characterized (CAS\#159217-95-5). TLC: mobile phase: EtOAc:hexanes (30:70), Rf: 0.64; 1H NMR (400 MHz, CDCl3) $\delta=7.12(\mathrm{t}, \mathrm{J}=7.7 \mathrm{~Hz}, 1 \mathrm{H}), 6.74-6.68(\mathrm{~m}, 2 \mathrm{H}), 6.58$ (dd, J = 2.1, $7.7 \mathrm{~Hz}, 1 \mathrm{H}$ ), 4.68 (s, $2 \mathrm{H}$ ), 3.66 (br. s., $2 \mathrm{H}$ ), 0.96 (s, $9 \mathrm{H}), 0.12$ (s, $6 \mathrm{H}$ ).<smiles>CCCCOCc1cccc(NC(=O)c2ccccc2Br)c1</smiles>

2-bromo-N-(3-\{[(tert-butyldimethylsilyl)oxy]methyl\}phenyl)benzamide (S9)

Aniline $\$ 8(250 \mathrm{mg}, 1.05 \mathrm{mmol})$ was added to a $100 \mathrm{~mL}$ round bottom flask with a magnetic stir bar, and then dissolved in anhydrous DCM $(6 \mathrm{~mL})$. The vessel was flushed with nitrogen for 5 min and to the suspension was added 2-bromobenzoic acid ( $240 \mathrm{mg}, 1.19 \mathrm{mmol}$ ), TEA (0.31 mL, $2.21 \mathrm{mmol}$ ), and BOP-Cl (293 mg, $1.09 \mathrm{mmol})$. The reaction mixture stirred for $19 \mathrm{~h}$ at room temperature and then monitored by TLC which showed consumption of starting material. The reaction was diluted with EtOAc $(30 \mathrm{~mL})$ and washed with half-saturated aq. $\mathrm{NaHCO}, 1 \mathrm{M} \mathrm{HCl}(30 \mathrm{~mL})$, brine, dried over $\mathrm{Na2SO}$, filtered, and concentrated under reduced pressure to give crude product. The crude material was passed through a silica plug using 5\% MeOH:DCM to yield $\mathrm{S} 9$ as a clear yellow liquid $(380 \mathrm{mg})$ in $86 \%$ yield. TLC: mobile phase: EtOAc: hexanes (30:70), Rf: 0.66; $1 \mathrm{H} \mathrm{NMR} \mathrm{(400} \mathrm{MHz}$ , $\mathrm{CDCl} 3$ ) $\delta=7.59$ (br. s., $1 \mathrm{H}), 7.35$ - $7.21(\mathrm{~m}, 4 \mathrm{H}), 7.11$ - $6.93(\mathrm{~m}, 3 \mathrm{H}), 6.84(\mathrm{~d}, \mathrm{~J}=7.6 \mathrm{~Hz}, 1 \mathrm{H}), 4.45(\mathrm{~s}, 2 \mathrm{H}), 0.65$ $(\mathrm{s}, 9 \mathrm{H}),-0.19(\mathrm{~s}, 6 \mathrm{H})$.<smiles>O=C(Nc1cccc(CO)c1)c1ccccc1Br</smiles>

S10

\section{2-bromo-N-[3-(hydroxymethyl)phenyl]benzamide (S10)}

To a $100 \mathrm{~mL}$ round bottom flask, $\mathrm{S} 9(300 \mathrm{mg}, 0.714 \mathrm{mmol}$ ) was added alongside a magnetic stir bar and diluted with anhydrous THF $(6 \mathrm{~mL})$. To the stirring reaction, $1 \mathrm{M} \mathrm{TBAF}$ in THF $(0.80 \mathrm{~mL}, 0.800 \mathrm{mmol})$ was added via syringe. The reaction was stirred at room temperature for $2 \mathrm{~h}$ before a sample aliquot was taken from the reaction, diluted with $\mathrm{DCM}$, and washed with half saturated $\mathrm{Na} 2 \mathrm{CO} 3$. The organic layer was separated and analyzed with TLC to confirm reaction completion. The reaction was diluted with sat. ammonium chloride (25 
$\mathrm{mL})$ and transferred to a separatory funnel and extracted with EtOAc $(2 \times 25 \mathrm{~mL})$. The organic layer was washed with brine, dried over $\mathrm{Na} 2 \mathrm{SO} 4$, filtered, and concentrated under reduced pressure to give crude product. The crude material was dissolved in a minimal amount of DCM, loaded onto a $10 \mathrm{~g}$ silica column, and purified by flash chromatography (EtOAc: hexanes, $20-100 \%$ ) to give S10 as a white solid (164 mg) in 90\% yield. TLC: mobile phase: EtOAc: hexanes (30:70), Rf: 0.23; $1 \mathrm{H} \mathrm{NMR} \mathrm{(400} \mathrm{MHz,} \mathrm{(CD3)2CO)} \delta=9.49$ (br. s., $1 \mathrm{H}), 7.84$ (s, $1 \mathrm{H}), 7.72$ $7.65(\mathrm{~m}, 2 \mathrm{H}), 7.57(\mathrm{dd}, \mathrm{J}=1.6,7.6 \mathrm{~Hz}, 1 \mathrm{H}), 7.48(\mathrm{t}, \mathrm{J}=7.5 \mathrm{~Hz}, 1 \mathrm{H}), 7.43-7.36(\mathrm{~m}, 1 \mathrm{H}), 7.32(\mathrm{t}, \mathrm{J}=7.8 \mathrm{~Hz}, 1 \mathrm{H})$, 7.14 (d, J = 7.6 Hz, $1 \mathrm{H}), 4.64$ (s, $2 \mathrm{H}), 4.31$ (br. s., $1 \mathrm{H})$.<smiles>O=Cc1cccc(NC(=O)c2ccccc2Br)c1</smiles>

\section{S11}

\section{2-bromo-N-(3-formylphenyl)benzamide (S11)}

To a $100 \mathrm{~mL}$ round bottom flask, alcohol S10 (105 mg, $0.343 \mathrm{mmol})$ was added alongside a magnetic stir bar. The starting material was dissolved in DCM $(6 \mathrm{~mL})$ and DMP $(382 \mathrm{mg}, 0.901 \mathrm{mmol})$ was added with along with DI water $(0.02 \mathrm{~mL})$. The reaction was heated to $30^{\circ} \mathrm{C}$ for $2.5 \mathrm{~h}$ and was then monitored by TLC which showed consumption of starting material. The reaction was filtered through a funnel packed with Celite. The filter cake was washed with DCM and the filtrate was concentrated under reduced pressure, to give crude material. The crude material was dissolved in a minimal amount of DCM and loaded onto a $10 \mathrm{~g}$ silica column, and purified by flash chromatography (EtOAc:hexanes, $20-100 \%$ ) to give S11 as a white solid ( $80 \mathrm{mg}$ ) in $77 \%$ yield. This compound has been previously reported and characterized (CAS\#1968124-06-2). TLC: mobile phase: MeOH:DCM (4:96), Rf: 0.80; $1 \mathrm{H} \mathrm{NMR} \mathrm{(400} \mathrm{MHz,} \mathrm{CD3OD)} \delta=9.99(\mathrm{~s}, 1 \mathrm{H}), 8.28(\mathrm{t}, \mathrm{J}=1.8 \mathrm{~Hz}, 1 \mathrm{H}), 7.95$ (ddd, J = 1.1, 2.2, 8.1 Hz, 1 H), $7.74-7.66(\mathrm{~m}, 2 \mathrm{H}), 7.61-7.52(\mathrm{~m}, 2 \mathrm{H}), 7.48(\mathrm{dt}, \mathrm{J}=1.2,7.5 \mathrm{~Hz}, 1 \mathrm{H}), 7.43-7.35(\mathrm{~m}, 1 \mathrm{H})$.

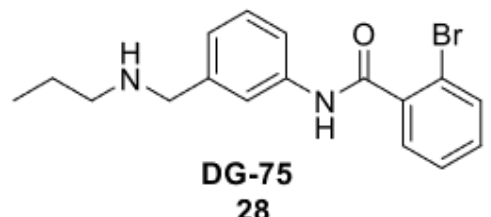

2-bromo-N-\{3-[(propylamino)methyl]phenyl\}benzamide (28)

To a $100 \mathrm{~mL}$ round bottom flask was added a magnetic stir bar and $40 \mathrm{mg}$ of 3 Å molecular sieves. Aldehyde S11 ( $38.5 \mathrm{mg}, 0.127 \mathrm{mmol}$ ) was added to the round bottom flask alongside DCE ( $4 \mathrm{~mL}$ ) and acetic acid (170 $\mu \mathrm{L}, 0.297$ $\mathrm{mmol})$. The vessel was sealed and flushed with nitrogen gas for $5 \mathrm{~min}$ and to this propylamine $(250 \mu \mathrm{L}, 0.304$ $\mathrm{mmol}$ ) was syringed into the flask. The mixture stirred at room temperature for $1 \mathrm{~h}$ before STAB (59.1 mg, 0.279 $\mathrm{mmol}$ ) was added, and the reaction was allowed to stir at room temperature for an additional $21 \mathrm{~h}$. A sample aliquot was taken from the reaction, diluted with $\mathrm{DCM}$, and washed with half saturated $\mathrm{Na2CO}$. The organic layer was separated and analyzed with TLC to confirm reaction completion. The reaction was diluted with DCM $(10 \mathrm{~mL})$, washed with half-saturated aq. NaHCO3 $(2 \times 15 \mathrm{~mL})$, dried over Na2SO4, filtered, and concentrated under reduced pressure to give crude product. The crude product was dissolved in a minimal amount of DCM, loaded onto a $10 \mathrm{~g}$ silica column, and purified with flash chromatography (MeOH:DCM, 2-16\% to give amine 28 (32 $\mathrm{mg}$ ) as a clear oil in $73 \%$ yield. The product was converted to the $\mathrm{HCl}$ salt by adding $0.9 \mathrm{M} \mathrm{HCl}$ in ether $(0.14$ $\mathrm{mL}$ ) and lyophilizing overnight to give the $\mathrm{HCl}$ salt as an off-white solid. TLC: mobile phase: $\mathrm{MeOH}: \mathrm{DCM}$ (10:90), Rf: 0.46; $1 \mathrm{H} \mathrm{NMR}(300 \mathrm{MHz}, \mathrm{D} 2 \mathrm{O}) \delta=7.58-7.33(\mathrm{~m}, 2 \mathrm{H}), 7.33-7.01(\mathrm{~m}, 7 \mathrm{H}), 4.61(\mathrm{~s}, 2 \mathrm{H}), 2.85-2.69(\mathrm{~m}, 2 \mathrm{H})$, $1.52-1.35(\mathrm{~m}, 2 \mathrm{H}), 0.74-0.61(\mathrm{~m}, 3 \mathrm{H})$. 


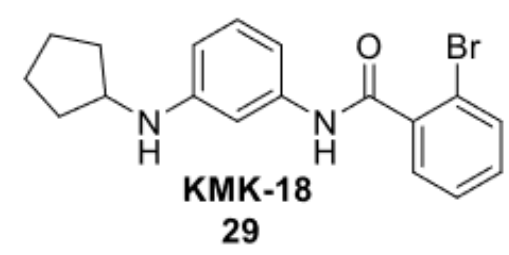

\section{2-bromo-N-[3-(cyclopentylamino)phenyl]benzamide (29)}

To a $50 \mathrm{~mL}$ round bottom flask was added a magnetic stir bar and $40 \mathrm{mg}$ of $3 \AA$ A molecular sieves.

cyclopentanone $(988 \mu \mathrm{L}, 11.2 \mathrm{mmol})$ was added to the round bottom flask alongside methanol $(8 \mathrm{~mL})$ and Acetic acid $(32.0 \mu \mathrm{L}, 0.558 \mathrm{mmol})$. The vessel was sealed and flushed with nitrogen gas for $2 \mathrm{~min}$ and to this S3 was added into the flask. The mixture was cooled to $0^{\circ} \mathrm{C}$ and allowed to stir for 30 min before $\mathrm{NaBH} 3 \mathrm{CN}(140 \mathrm{mg}$, $2.23 \mathrm{mmol}$ ) was added. The reaction was allowed to stir at $0^{\circ} \mathrm{C}$ and gradually allowed to warm up to room temperature for an additional $1 \mathrm{~h}$. A sample aliquot was taken from the reaction, diluted with DCM, and washed with half saturated $\mathrm{Na2CO}$. The organic layer was separated and analyzed with LCMS to confirm reaction completion. The reaction was diluted with DCM $(10 \mathrm{~mL})$, washed with half-saturated aq. NaHCO3 $(2 \times 15 \mathrm{~mL})$, dried over $\mathrm{Na} 2 \mathrm{SO} 4$, filtered, and concentrated under reduced pressure to give crude product. The crude product was dissolved in a minimal amount of DCM, loaded onto a $10 \mathrm{~g}$ silica column, and purified with flash chromatography (EtOAc:hexanes, 10-60\%) to give amine $29(385 \mathrm{mg})$ as a yellow solid in $96 \%$ yield. LC/MS tR = $5.24 \mathrm{~min}$ (Characterization Method A); $\mathrm{m} / \mathrm{z}=360.85(\mathrm{M}+\mathrm{H}) ; 1 \mathrm{H} \mathrm{NMR}(300 \mathrm{MHz}, \mathrm{CDCl} 3) \delta 7.75$ (br. s., $1 \mathrm{H}), 7.57$ (ddd, J = 9.7, 7.7, $1.6 \mathrm{~Hz}, 2 \mathrm{H}), 7.35(\mathrm{td}, \mathrm{J}=7.5,1.3 \mathrm{~Hz}, 1 \mathrm{H}), 7.31-7.23(\mathrm{~m}, 1 \mathrm{H}), 7.17(\mathrm{t}, \mathrm{J}=2.0 \mathrm{~Hz}, 1 \mathrm{H}), 7.11(\mathrm{t}, \mathrm{J}=$ $8.0 \mathrm{~Hz}, 1 \mathrm{H}), 6.74-6.70(\mathrm{~m}, 1 \mathrm{H}), 6.39(\mathrm{ddd}, \mathrm{J}=8.2,2.3,0.9 \mathrm{~Hz}, 1 \mathrm{H}), 3.83-3.73(\mathrm{~m}, 1 \mathrm{H}), 2.16-1.92(\mathrm{~m}, 4 \mathrm{H}), 1.74-$ $1.45(\mathrm{~m}, 4 \mathrm{H}) .13 \mathrm{C}$ NMR $(75 \mathrm{MHz}, \mathrm{CDCl} 3) \delta=165.8,149.1,138.8,138.3,133.6,131.7,129.9,127.9,119.5,109.7$, $108.5,105.0,54.8,38.6,33.8,24.3,23.5$.

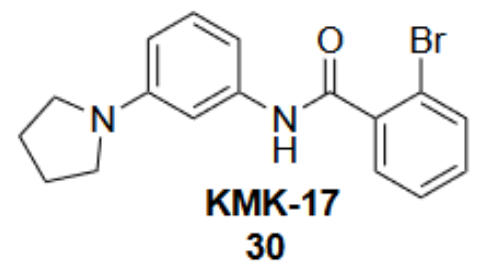

\section{2-bromo-N-[3-(pyrrolidin-1-yl)phenyl]benzamide KMK-17 (30)}

To a round bottom flask was added aniline S3 (264 mg, $0.908 \mathrm{mmol}), \mathrm{K} 2 \mathrm{CO} 3(157 \mathrm{mg}, 1.13 \mathrm{mmol})$, a cat. amount of $\mathrm{KI}(0.753 \mathrm{mg}, 0.00454 \mathrm{mmol})$ and a magnetic stir bar. The flask was sealed and flushed with nitrogen gas for 5 $\mathrm{min}$. The contents were dissolved in anhydrous acetonitrile $(10 \mathrm{~mL})$ and then 1,4-dibromobutane $(54 \mu \mathrm{L}, 0.454$ $\mathrm{mmol}$ ) was added via syringe to the flask and stirred at $50{ }^{\circ} \mathrm{C}$ for $30 \mathrm{~min}$. After $30 \mathrm{~min}$, a sample aliquot was taken from the reaction, concentrated under reduced pressure, dissolved in a minimal amount of HPLC grade $\mathrm{MeCN}$, and analyzed with LCMS which showed no reaction. Toluene $(10 \mathrm{~mL})$ was introduced into the reaction and the reaction was heated to $90^{\circ} \mathrm{C}$ for $24 \mathrm{~h}$. A sample aliquot was taken from the reaction and analyzed with LCMS to show reaction completion. The reaction was diluted with EtOAc $(30 \mathrm{~mL})$, washed with half-saturated aq. $\mathrm{NaHCO} 3(2 \times 15 \mathrm{~mL})$, dried over with Na2SO4, filtered, and concentrated under reduced pressure to give crude product. The crude product was dissolved in a minimal amount of DCM, loaded onto a $10 \mathrm{~g}$ silica column, and purified with flash chromatography (EtOAc:hexane, $10-70 \%$ to give $30(135 \mathrm{mg})$ as a yellow solid in $86 \%$ yield. $\mathrm{LC} / \mathrm{MS} \mathrm{tR}=6.05 \mathrm{~min}($ Characterization Method A); $\mathrm{m} / \mathrm{z}=346.85(\mathrm{M}+\mathrm{H}) ; 1 \mathrm{H} \mathrm{NMR}(300 \mathrm{MHz}, \mathrm{CDCl} 3) \delta=7.63(\mathrm{td}$, $\mathrm{J}=1.8,7.7 \mathrm{~Hz}, 2 \mathrm{H}), 7.59$ (br. s., $1 \mathrm{H}), 7.39$ (dt, J = 1.2, 7.5 Hz, $1 \mathrm{H}), 7.36-7.27(\mathrm{~m}, 1 \mathrm{H}), 7.19(\mathrm{t}, \mathrm{J}=8.1 \mathrm{~Hz}, 1 \mathrm{H})$, $7.03(\mathrm{t}, \mathrm{J}=2.0 \mathrm{~Hz}, 1 \mathrm{H}), 6.79(\mathrm{dd}, \mathrm{J}=1.2,7.9 \mathrm{~Hz}, 1 \mathrm{H}), 6.38(\mathrm{dd}, \mathrm{J}=2.0,8.1 \mathrm{~Hz}, 1 \mathrm{H}), 3.37-3.26(\mathrm{~m}, 4 \mathrm{H}), 2.06-$ $1.94(\mathrm{~m}, 4 \mathrm{H})$. 


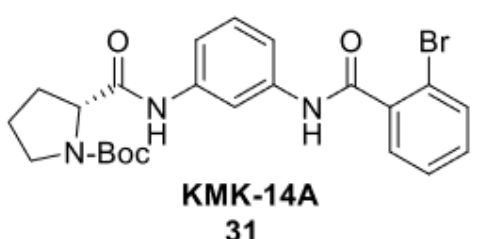

tert-butyl (2R)-2-\{[3-(2-bromobenzamido)phenyl]carbamoyl\}pyrrolidine-1-carboxylate (31)

Analogue (31) was synthesized by coupling S3 with Boc-D-proline (133 mg, $0.619 \mathrm{mmol}$ ) according to general method D. The crude material was dissolved in a minimal amount of DCM, loaded onto a $25 \mathrm{~g}$ silica column, and purified by flash chromatography (EtOAc:hexanes, $0-50 \%)$ to give 31 as a white solid $(150 \mathrm{mg})$ in $74 \%$ yield. $\mathrm{LC} / \mathrm{MS} \mathrm{tR}=5.70 \mathrm{~min}($ Characterization Method A); $\mathrm{m} / \mathrm{z}=488.00(\mathrm{M}+\mathrm{H}) ; 1 \mathrm{H} \mathrm{NMR}(400 \mathrm{MHz}, \mathrm{CD} 3 \mathrm{OD}) \delta=8.05-$ $7.95(\mathrm{~m}, 1 \mathrm{H}), 7.66(\mathrm{~d}, \mathrm{~J}=8.0 \mathrm{~Hz}, 1 \mathrm{H}), 7.54-7.22(\mathrm{~m}, 7 \mathrm{H}), 4.36-4.22(\mathrm{~m}, 1 \mathrm{H}), 3.59-3.40(\mathrm{~m}, 2 \mathrm{H}), 2.35-2.20$ $(\mathrm{m}, 1 \mathrm{H}), 2.03(\mathrm{br} \mathrm{s}, 3 \mathrm{H}), 1.88(\mathrm{~d}, \mathrm{~J}=6.8 \mathrm{~Hz}, 1 \mathrm{H}), 1.45(\mathrm{br} \mathrm{s}, 3 \mathrm{H}), 1.37(\mathrm{~s}, 7 \mathrm{H})$.

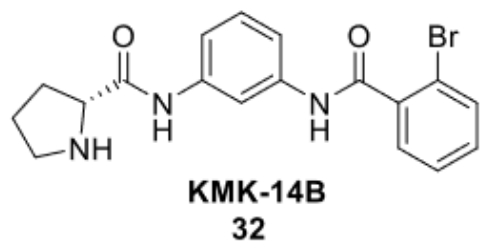

(2R)-N-[3-(2-bromobenzamido)phenyl]pyrrolidine-2-carboxamide (32)

To a $25 \mathrm{~mL}$ round bottom flask with a stir bar was added $31(76 \mathrm{mg}, 0.156 \mathrm{mmol})$ and anhydrous DCM $(5 \mathrm{~mL})$, which was subsequently flushed with nitrogen gas for 5 minutes. To the sealed flask, via syringe, was added $4 \mathrm{M}$ $\mathrm{HCl}$ in dioxane $(1.20 \mathrm{~mL})$. The reaction was allowed to stir at room temperature for $1 \mathrm{~h}$. The reaction mixture was concentrated under reduced pressure (passed through a base trap) to give crude material that was suspended in EtOAc and washed with half-saturated aq. $\mathrm{NaHCO}$, and brine. The reaction was dried over $\mathrm{Na} 2 \mathrm{SO} 4$, filtered, and concentrated under reduced pressure to give crude material. The crude material was dissolved in a minimal amount of DCM, loaded onto a $10 \mathrm{~g}$ silica column, and purified by flash chromatography ( $\mathrm{MeOH}: \mathrm{DCM}, 0-6 \%)$ to give 32 as a white solid $(42 \mathrm{mg}$ ) in $69 \%$ yield. Note: after the purification the free-amine was converted to the $\mathrm{HCl}$ salt by introducing excess $4 \mathrm{M} \mathrm{HCl}$ in dioxane and subsequently removing the acid under reduced pressure (through a base trap). LC/MS tR $=2.59 \mathrm{~min}$ (Characterization Method $\mathrm{A}$ ); $\mathrm{m} / \mathrm{z}=389.00$ $(\mathrm{M}+\mathrm{H})$; $1 \mathrm{H}$ NMR $(400 \mathrm{MHz}, \mathrm{CD} 30 \mathrm{O}) \delta=8.00(\mathrm{t}, \mathrm{J}=2.0 \mathrm{~Hz}, 1 \mathrm{H}), 7.69-7.63(\mathrm{~m}, 1 \mathrm{H}), 7.55-7.33(\mathrm{~m}, 5 \mathrm{H}), 7.33-$ $7.23(\mathrm{~m}, 1 \mathrm{H}), 3.83(\mathrm{dd}, \mathrm{J}=6.0,8.7 \mathrm{~Hz}, 1 \mathrm{H}), 3.14-2.94(\mathrm{~m}, 2 \mathrm{H}), 2.30-2.17(\mathrm{~m}, 1 \mathrm{H}), 1.95-1.76(\mathrm{~m}, 3 \mathrm{H})$.

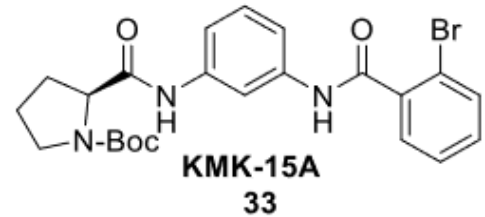

tert-butyl (2S)-2-\{[3-(2-bromobenzamido)phenyl]carbamoyl\}pyrrolidine-1-carboxylate (33)

Analogue (33) was synthesized by coupling S3 with Boc-L-proline (150 mg, $0.697 \mathrm{mmol}$ ) according to general method D. The crude material was dissolved in a minimal amount of DCM, loaded onto a $25 \mathrm{~g}$ silica column, and purified by flash chromatography (EtOAc:hexanes, $0-50 \%)$ to give 33 as a white solid $(158 \mathrm{mg})$ in $70 \%$ yield. $\mathrm{LC} / \mathrm{MS} \mathrm{tR}=5.69 \mathrm{~min}($ Characterization Method $\mathrm{A}) ; \mathrm{m} / \mathrm{z}=488.95(\mathrm{M}+\mathrm{H}) ; 1 \mathrm{H} \mathrm{NMR}(400 \mathrm{MHz}, \mathrm{CD} 3 \mathrm{OD}) \delta=8.05-$ $7.95(\mathrm{~m}, 1 \mathrm{H}), 7.66(\mathrm{~d}, \mathrm{~J}=8.0 \mathrm{~Hz}, 1 \mathrm{H}), 7.54-7.23(\mathrm{~m}, 7 \mathrm{H}), 4.37-4.20(\mathrm{~m}, 1 \mathrm{H}), 3.59-3.37(\mathrm{~m}, 2 \mathrm{H}), 2.36-2.19$ (m, $1 \mathrm{H}), 2.05-1.93(\mathrm{~m}, 3 \mathrm{H}), 1.93-1.80(\mathrm{~m}, 1 \mathrm{H}), 1.45(\mathrm{~s}, 3 \mathrm{H}), 1.39(\mathrm{~s}, 7 \mathrm{H})$. 


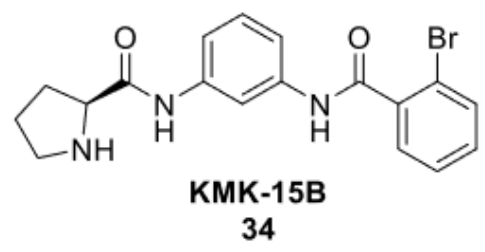

(2S)-N-[3-(2-bromobenzamido)phenyl]pyrrolidine-2-carboxamide (34)

To a $25 \mathrm{~mL}$ round bottom flask with a stir bar was added 33 (36 mg, $0.074 \mathrm{mmol}$ ) and anhydrous DCM ( $5 \mathrm{~mL}$ ), which was subsequently flushed with nitrogen gas for 5 minutes. To the sealed flask, via syringe, was added $4 \mathrm{M}$ $\mathrm{HCl}$ in dioxane $(1 \mathrm{~mL})$. The reaction was allowed to stir at room temperature for $1 \mathrm{~h}$. The reaction mixture was concentrated under reduced pressure (passed through a base trap) to give crude material that was suspended in EtOAc and washed with half-saturated aq. $\mathrm{NaHCO} 3$, and brine. The reaction was dried over $\mathrm{Na2SO} 4$, filtered, and concentrated under reduced pressure to give crude material. The crude material was dissolved in a minimal amount of DCM, loaded onto a $10 \mathrm{~g}$ silica column, and purified by flash chromatography (MeOH:DCM, 0-6\%) to give 34 as a white solid ( $22 \mathrm{mg}$ ) in $78 \%$ yield. Note: after the purification the free-amine was converted to the $\mathrm{HCl}$ salt by introducing excess $4 \mathrm{M} \mathrm{HCl}$ in dioxane and subsequently removing the acid under reduced pressure (through a base trap). LC/MS tR $=2.55 \mathrm{~min}$ (Characterization Method A); $\mathrm{m} / \mathrm{z}=389.85(\mathrm{M}+\mathrm{H}) ; 1 \mathrm{H} \mathrm{NMR} \mathrm{(300}$ $\mathrm{MHz}, \mathrm{CD} 3 \mathrm{OD}) \delta=7.98-7.78(\mathrm{~m}, 1 \mathrm{H}), 7.65-7.44(\mathrm{~m}, 5 \mathrm{H}), 7.44-7.25(\mathrm{~m}, 6 \mathrm{H}), 6.91(\mathrm{~d}, \mathrm{~J}=7.6 \mathrm{~Hz}, 1 \mathrm{H}), 4.03$ (dd, $\mathrm{J}=4.6,9.5 \mathrm{~Hz}, 1 \mathrm{H}), 3.20-2.92(\mathrm{~m}, 1 \mathrm{H}), 2.69-2.56(\mathrm{~m}, 1 \mathrm{H}), 2.29-2.16(\mathrm{~m}, 1 \mathrm{H}), 2.08-1.72(\mathrm{~m}, 3 \mathrm{H})$.

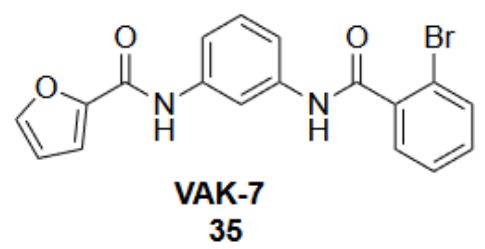

N-[3-(2-bromobenzamido)phenyl]furan-2-carboxamide (35)

Analogue (25) was synthesized via a peptide coupling between S3 (50.0 mg, $0.172 \mathrm{mmol})$, and furan-2-carboxylic acid (19.6 mg, $0.172 \mathrm{mmol}$ ) according to general method A. The crude material was dissolved in minimal DCM, loaded on to a $10 \mathrm{~g}$ silica column, and purified by flash chromatography (MeOH:DCM 0-10\%) to give 35 as an off white solid in 44\% yield. TLC: mobile phase: $\mathrm{MeOH}: \mathrm{DCM}(10: 90), \mathrm{Rf}: 0.85 ; \mathrm{LC} / \mathrm{MS}$ tR $=4.82$ min (Characterization Method A); $\mathrm{m} / \mathrm{z}=386.75(\mathrm{M}+\mathrm{H}) ; 1 \mathrm{H}$ NMR $(300 \mathrm{MHz}, \mathrm{CDCl} 3) \delta 8.17$ (br. s., $1 \mathrm{H}), 8.09(\mathrm{~s}, 1 \mathrm{H}), 7.86$ (br. s., $1 \mathrm{H})$, 7.64-7.60 (m, 2H), 7.55-7.50 (m, 2H), 7.46-7.29 (m, 5H), 7.22 (dd, J = 3.5, $0.8 \mathrm{~Hz}, 1 \mathrm{H}), 6.56(\mathrm{dd}, \mathrm{J}=3.5,1.8 \mathrm{~Hz}$, $1 \mathrm{H})$.<smiles>O=C(Nc1cccc(NC(=O)C2CCCO2)c1)c1ccccc1Br</smiles>

$\mathrm{N}$-[3-(2-bromobenzamido)phenyl]oxolane-2-carboxamide (36)

Analogue (36) was synthesized by acylating S3 with tetrahydrofuran-2-carboxylic acid ( $41 \mu \mathrm{L}, 0.431 \mathrm{mmol})$ according to general method B. The crude material was dissolved in a minimal amount of DCM, loaded onto a 10 g silica column, and purified by flash chromatography (EtOAc:hexanes, $0-100 \%$ ) to give 36 as a white solid (55 $\mathrm{mg}$ ) in 33\% yield. LC/MS tR $=5.22 \mathrm{~min}$ (Characterization Method A); $\mathrm{m} / \mathrm{z}=413.05(\mathrm{M}+\mathrm{Na}) ; 1 \mathrm{H} \mathrm{NMR}(300 \mathrm{MHz}$, $\mathrm{CDCl} 3) \delta=8.54(\mathrm{~s}, 1 \mathrm{H}), 7.98(\mathrm{t}, \mathrm{J}=1.9 \mathrm{~Hz}, 1 \mathrm{H}), 7.89$ (br. s., $1 \mathrm{H}), 7.67-7.55(\mathrm{~m}, 2 \mathrm{H}), 7.48-7.27(\mathrm{~m}, 5 \mathrm{H}), 4.41$ $(\mathrm{dd}, \mathrm{J}=5.9,8.3 \mathrm{~Hz}, 1 \mathrm{H}), 4.11-3.87(\mathrm{~m}, 2 \mathrm{H}), 2.42-2.25(\mathrm{~m}, 1 \mathrm{H}), 2.21-2.06(\mathrm{~m}, 1 \mathrm{H}), 2.02-1.85(\mathrm{~m}, 2 \mathrm{H})$. 
<smiles>O=C(Nc1cccc(NC(=O)C2CCOC2)c1)c1ccccc1Br</smiles>

$\mathrm{N}$-[3-(2-bromobenzamido)phenyl] oxolane-3-carboxamide (37)

Analogue (37) was synthesized by acylating $\mathrm{S} 3$ with tetrahydrofuran-3-carboxylic acid ( $41 \mu \mathrm{L}, 0.431 \mathrm{mmol})$ according to general method $B$. The crude material was dissolved in a minimal amount of DCM, loaded onto a 10 g silica column, and purified by flash chromatography (EtOAc:hexanes, $0-100 \%$ ) to give 37 as a white solid (32 $\mathrm{mg}$ ) in $19 \%$ yield. $\mathrm{LC} / \mathrm{MS} \mathrm{tR}=5.22 \mathrm{~min}$ (Characterization Method $\mathrm{B}) ; \mathrm{m} / \mathrm{z}=387.05(\mathrm{M}+\mathrm{H}) ; 1 \mathrm{H} \mathrm{NMR}(400 \mathrm{MHz}$, (CD3)2SO) $\delta=10.09$ (br. s., $1 \mathrm{H}), 8.08(\mathrm{~s}, 1 \mathrm{H}), 7.70(\mathrm{~d}, \mathrm{~J}=7.7 \mathrm{~Hz}, 1 \mathrm{H}), 7.55-7.45(\mathrm{~m}, 2 \mathrm{H}), 7.44-7.35(\mathrm{~m}, 2 \mathrm{H})$, $7.33-7.18(\mathrm{~m}, 2 \mathrm{H}), 3.92(\mathrm{t}, \mathrm{J}=8.2 \mathrm{~Hz}, 1 \mathrm{H}), 3.81-3.63(\mathrm{~m}, 3 \mathrm{H}), 3.21-3.07(\mathrm{~m}, 1 \mathrm{H}), 2.13-1.97(\mathrm{~m}, 2 \mathrm{H})$.<smiles>O=C(Nc1cccc(NC(=O)c2ccccc2Br)c1)c1cocn1</smiles>

N-[3-(2-bromobenzamido)phenyl]-1,3-oxazole-4-carboxamide (39)

Analogue (39) was synthesized by acylating S3 with oxazole-4-carboxylic acid (19.7 mg, $0.174 \mathrm{mmol}$ ) according to general method $A$. The crude material was dissolved in a minimal amount of DCM, loaded onto a $5 \mathrm{~g}$ silica column, and purified by flash chromatography ( $\mathrm{MeOH}: \mathrm{DCM}, 0-8 \%$ ) to give 39 as a yellow oil (19 $\mathrm{mg}$ ) in $29 \%$ yield. $L C / M S t R=4.56$ min (Characterization Method A); $\mathrm{m} / \mathrm{z}=387.05(\mathrm{M}+\mathrm{H}) ; 1 \mathrm{H} \mathrm{NMR}(300 \mathrm{MHz},(\mathrm{CD} 3) 2 \mathrm{CO}) \delta$ $=9.50(\mathrm{~d}, \mathrm{~J}=1.0 \mathrm{~Hz}, 1 \mathrm{H}), 8.58(\mathrm{~d}, \mathrm{~J}=1.0 \mathrm{~Hz}, 1 \mathrm{H}), 8.40-8.30(\mathrm{~m}, 2 \mathrm{H}), 7.73-7.55(\mathrm{~m}, 5 \mathrm{H}), 7.55-7.30(\mathrm{~m}, 4 \mathrm{H})$.

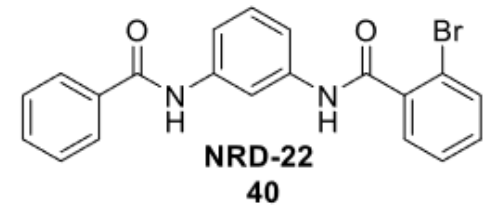

\section{$\mathrm{N}$-(3-benzamidophenyl)-2-bromobenzamide (40)}

Analogue (40) was synthesized by acylating S3 with benzoyl chloride $(29.1 \mathrm{mg}, 0.207 \mathrm{mmol})$ according to general method $\mathrm{A}$. The crude material was dissolved in a minimal amount of DCM, loaded onto a $5 \mathrm{~g}$ silica column, and purified by flash chromatography ( $\mathrm{MeOH}: \mathrm{DCM}, 0-8 \%$ ) to give 40 as a yellow oil $(32 \mathrm{mg})$ in $46 \%$ yield. LC/MS tR = $5.23 \mathrm{~min}$ (Characterization Method A); $\mathrm{m} / \mathrm{z}=396.75(\mathrm{M}+\mathrm{H}) ; 1 \mathrm{H} \mathrm{NMR}(300 \mathrm{MHz}, \mathrm{CD} 3 \mathrm{OD}) \delta=8.14(\mathrm{t}, \mathrm{J}=1.9 \mathrm{~Hz}, 1$ H), 7.96 - $7.89(\mathrm{~m}, 2 \mathrm{H}), 7.68(\mathrm{dd}, \mathrm{J}=0.8,7.9 \mathrm{~Hz}, 1 \mathrm{H}), 7.62$ - $7.42(\mathrm{~m}, 7 \mathrm{H}), 7.41-7.30(\mathrm{~m}, 2 \mathrm{H})$. 
4. Compound characterization data

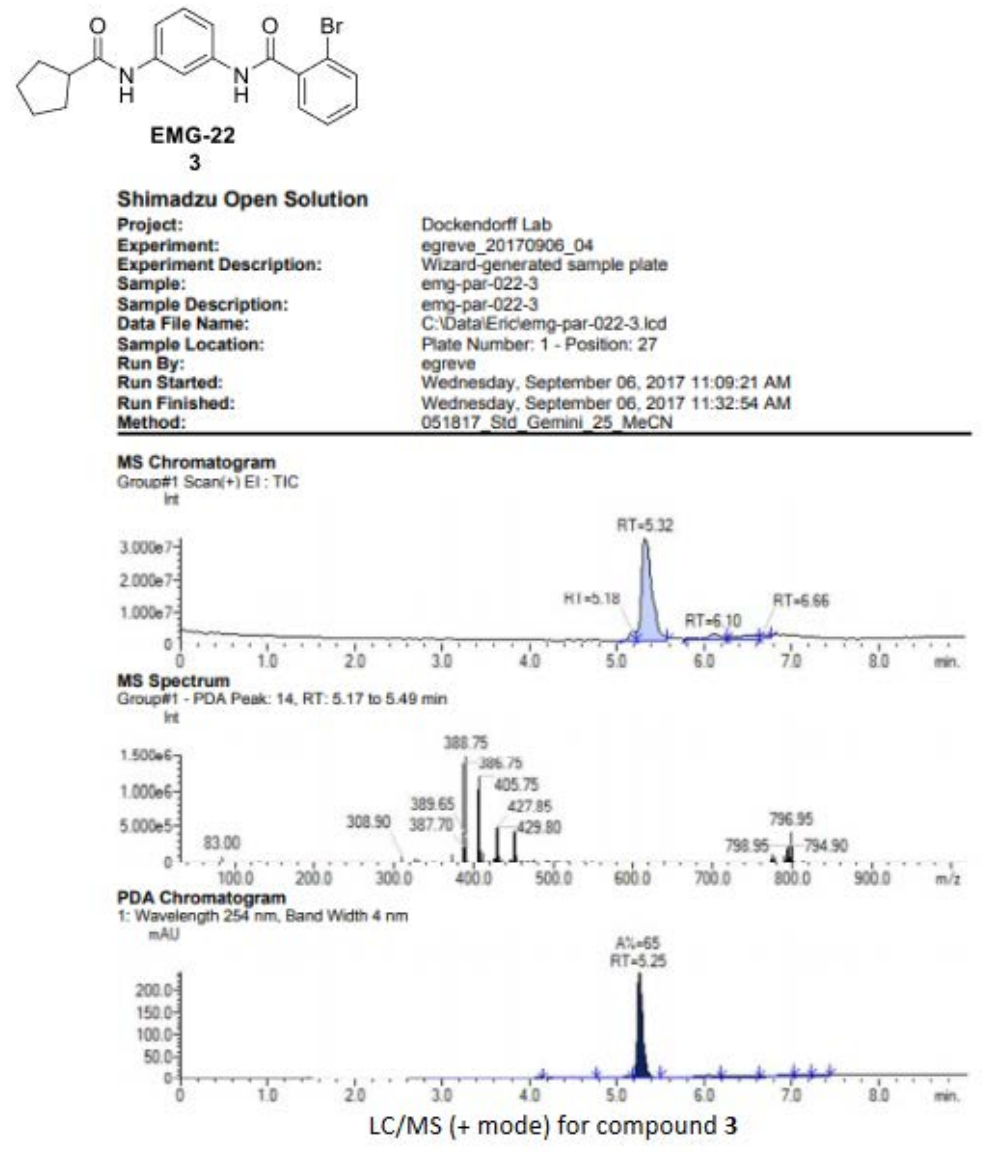

LC/MS (+ mode) for compound 3 

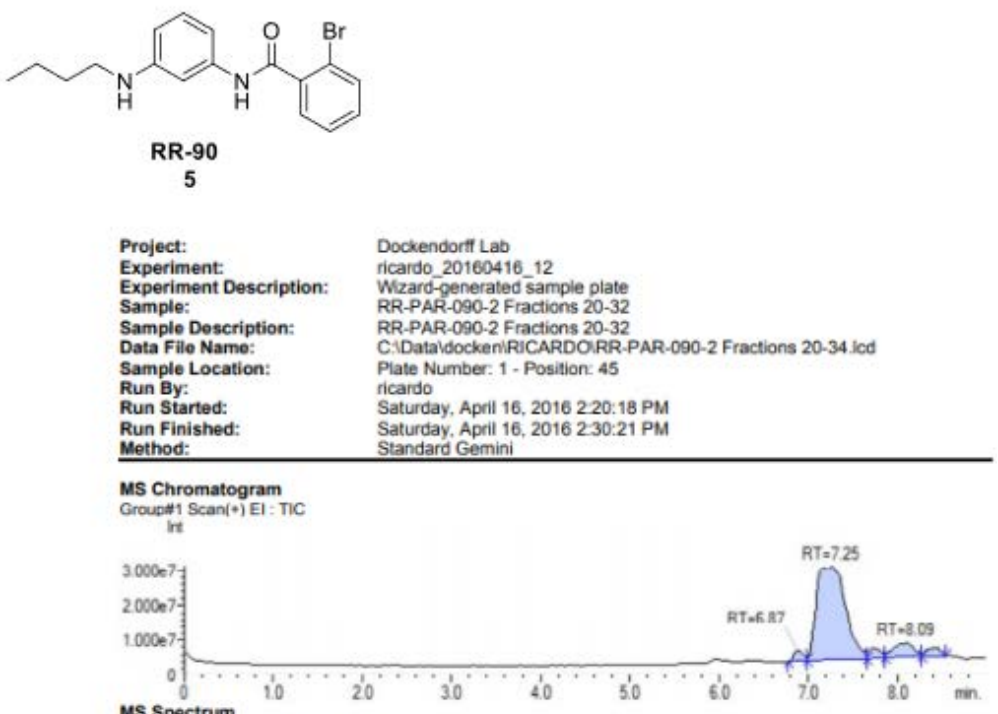

MS Spectrum
Groupt1-PDA Peak: 11, RT: 6.88 to $8.98 \mathrm{~min}$

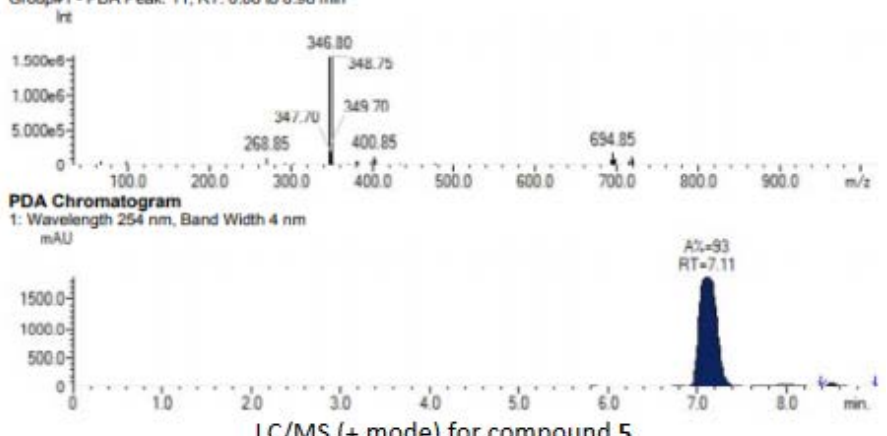
LC/MS (+ mode) for compound 5

\section{S-30LC/MS (+ mode) for compound 5}




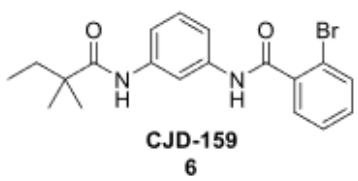

\begin{tabular}{|c|c|}
\hline $\begin{array}{l}\text { Project: } \\
\text { Experiment: } \\
\text { Experiment Description: } \\
\text { Sample: } \\
\text { Sample Description: } \\
\text { Data File Name: } \\
\text { Sample Location: } \\
\text { Run By: } \\
\text { Run Started: } \\
\text { Run Finished: } \\
\text { Method: }\end{array}$ & $\begin{array}{l}\text { Dockendortt Lab } \\
\text { dibyn_20180528_08 } \\
\text { Wizard-generated sample plate } \\
\text { NDRD-PAR-028-1-3-1 } \\
\text { NDRD-PAR-028-1-3-1 } \\
\text { C.DataidockenlRolandwDRD-PAR-028-1-3-1.lod } \\
\text { Plate Number. 1- Position: 62 } \\
\text { dibyn } \\
\text { Monday, May 28, 2018 2:18:43 PM } \\
\text { Monday, May 28, 2018 2:28:46 PM } \\
\text { 051817. Std Gemini 25 MeCN }\end{array}$ \\
\hline
\end{tabular}

MS Chromatogram

Groupliti Scan(*) EI : TIC

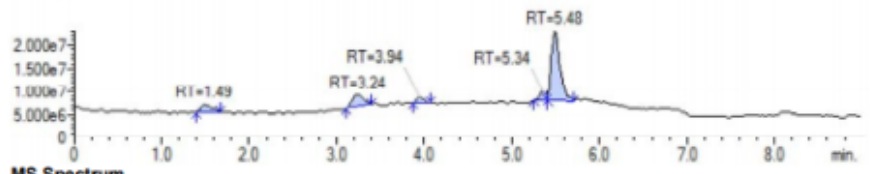

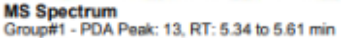

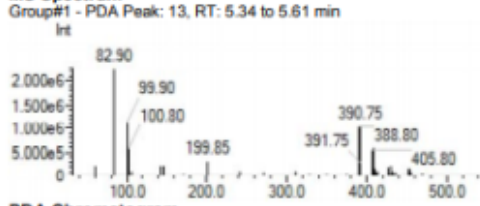

PDA Chromatogram

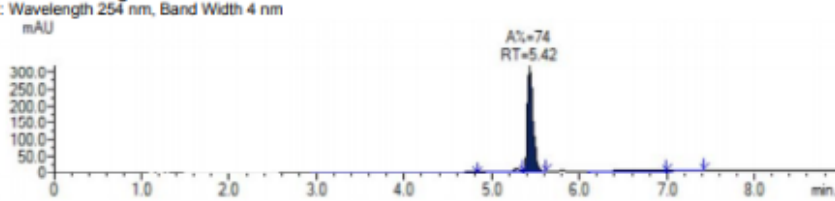

LC/MS (+ mode) for compound 6

LC/MS (+ mode) for compound 6 

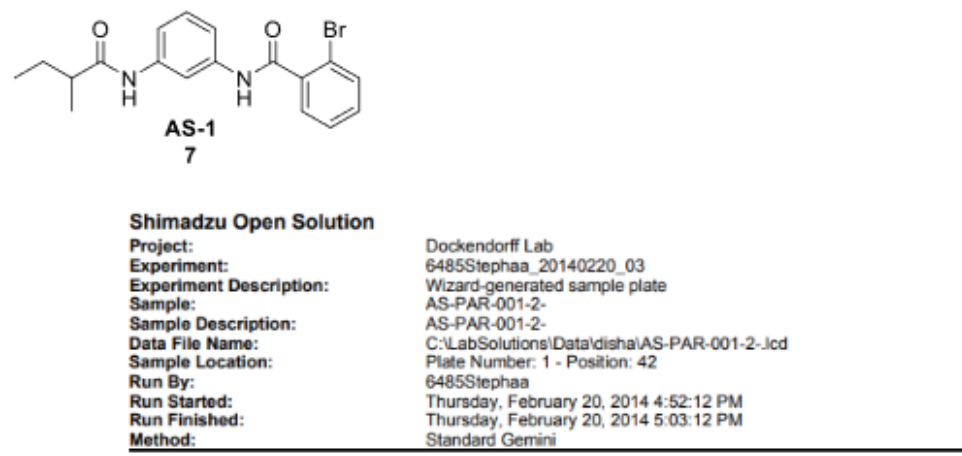

Run Finishe
Method:

MS Chromatogram
Group\#2 Scan(-) EI : TIC

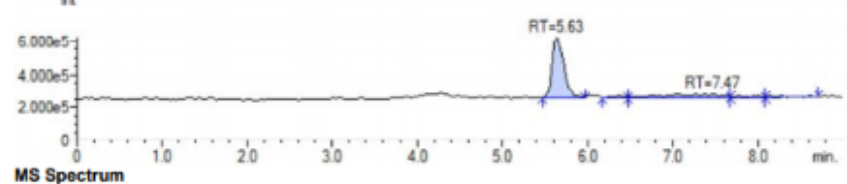

MS Spectrum
Group 22 - PDA Peak: 18, RT: 5.41 to $8.66 \mathrm{~min}$

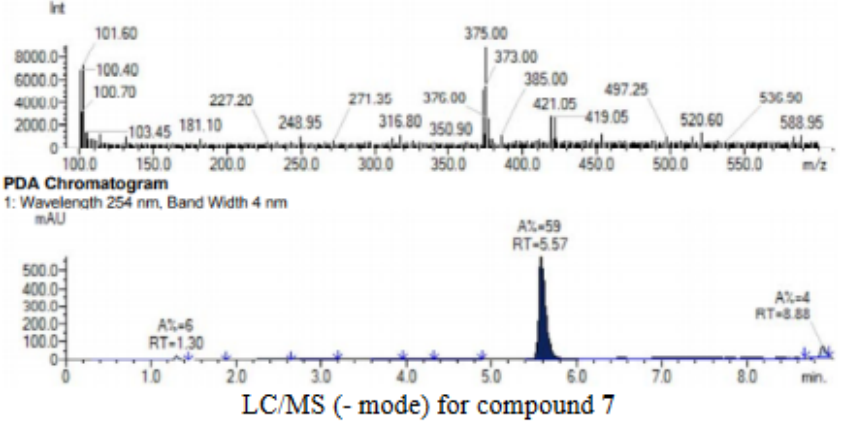

LC/MS (- mode) for compound 7
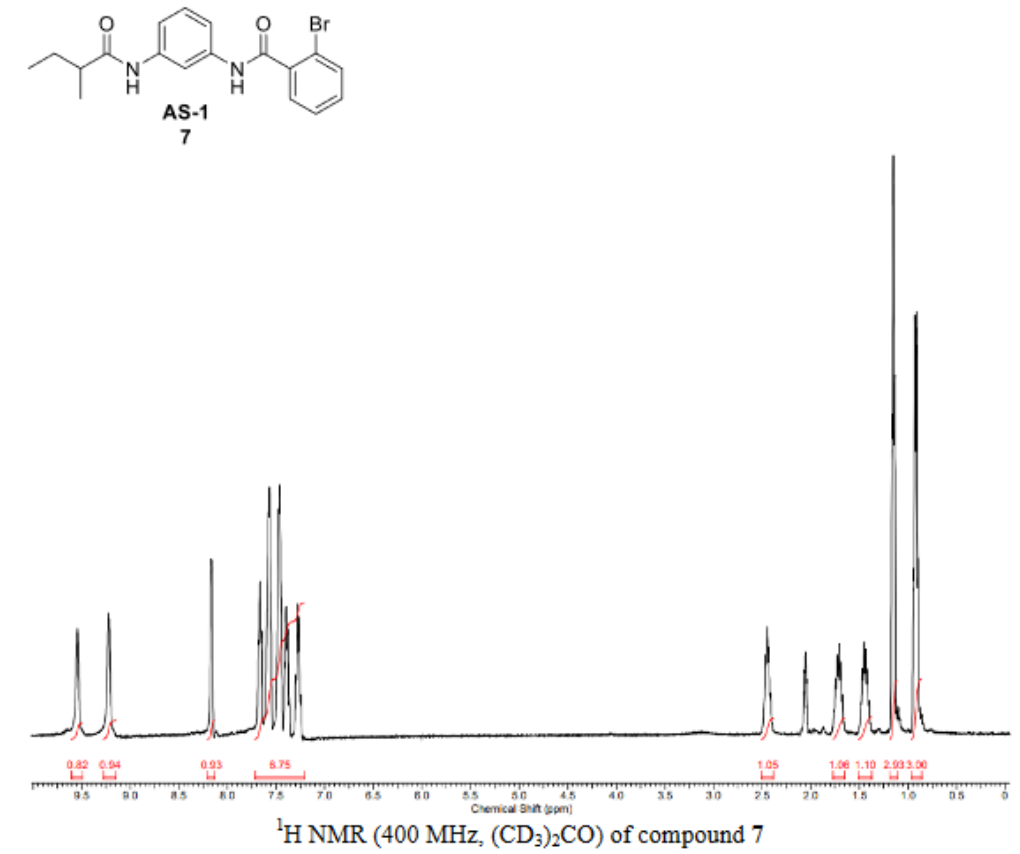

${ }^{1} \mathrm{H}$ NMR $\left(400 \mathrm{MHz},\left(\mathrm{CD}_{3}\right)_{2} \mathrm{CO}\right)$ of compound 7 


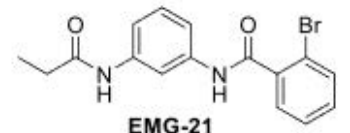

8

Project:

Excription:

Sample:

Sample Description:

Data File Name:

Run By:
Run Started:

Run Finished:

Method:

MS Chromatogram

Groupt Scan (+) E1 : T)

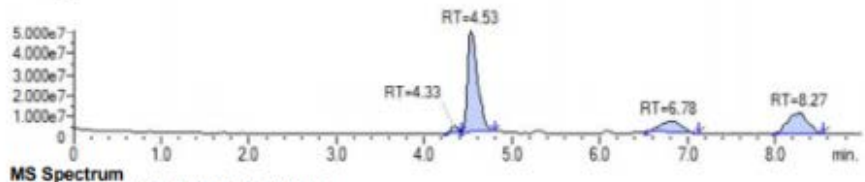

MS Spectrum

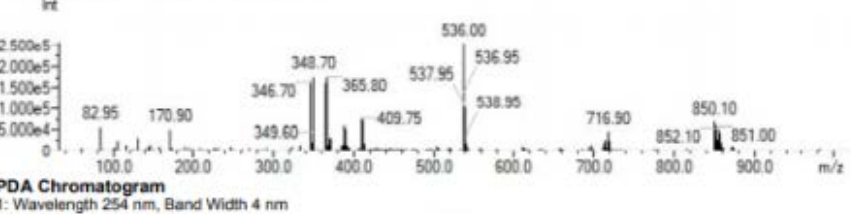

Waveiength $254 \mathrm{~nm}$, Band Width $4 \mathrm{~nm}$

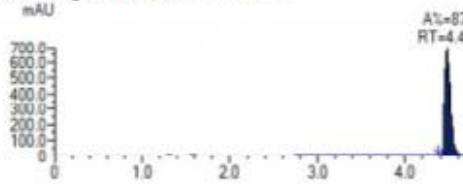

LC/MS (+ mode) for compound 8

egreve_20170908_03

Weard-generated sample plate

emg-par-021-3-12

C:Datai Ericlemg-par-021-3.2. vod

Plate Number 1 - Posison: 40

Friday, September 08, 2017 8:14:37 AM

Friday, September 08, 2017 8.24:37 AM

051817 Sid Gemini_25 MeCN 

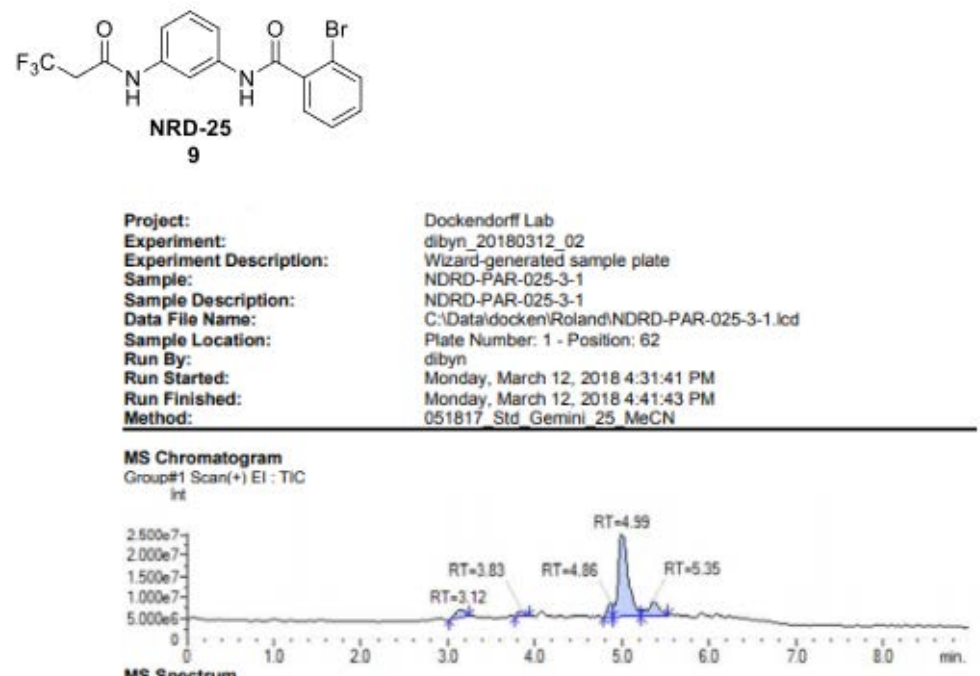

MS Spectrum

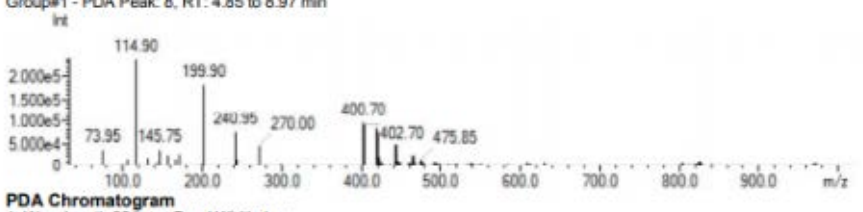

PDA Chromatogram

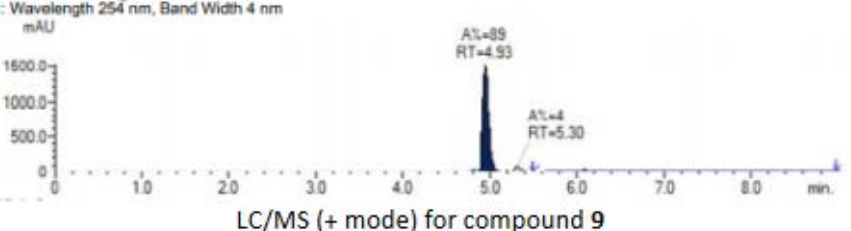

LC/MS (+ mode) for compound 9

LC/MS (+ mode) for compound 9

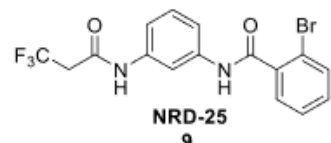

9

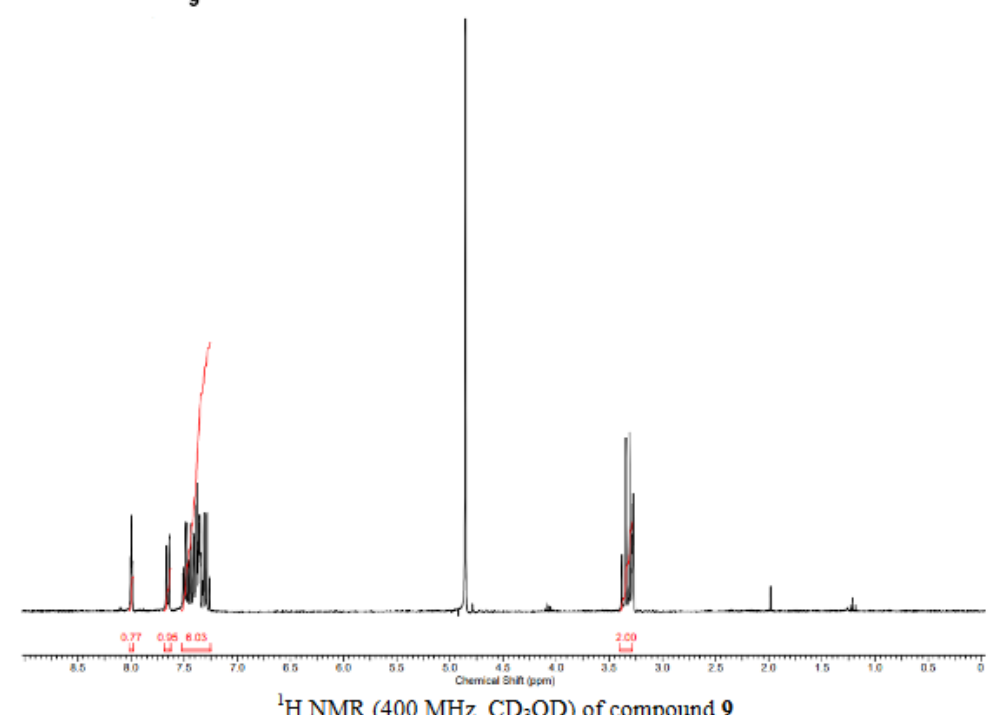

${ }^{1} \mathrm{H}$ NMR ( $400 \mathrm{MHz}, \mathrm{CD}_{3} \mathrm{OD}$ ) of compound 9

${ }^{1} \mathrm{H}$ NMR (400 MHz, $\mathrm{CD}_{3} \mathrm{OD}$ ) of compound 9 


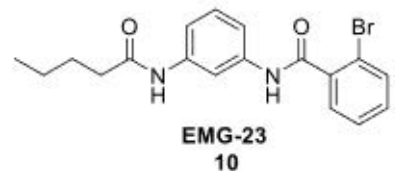

\begin{tabular}{|c|c|}
\hline $\begin{array}{l}\text { Project: } \\
\text { Experiment: } \\
\text { Experiment Description: } \\
\text { Sample: } \\
\text { Sample Description: } \\
\text { Data File Name: } \\
\text { Samplo Location: } \\
\text { Run By: } \\
\text { Run Started: } \\
\text { Run Finished: } \\
\text { Method: }\end{array}$ & 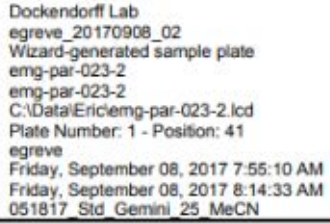 \\
\hline
\end{tabular}

Finday, September 08, 2017 8:14:33 AM

MS Chromatogram
Group=1 Scan(t) El : TIC

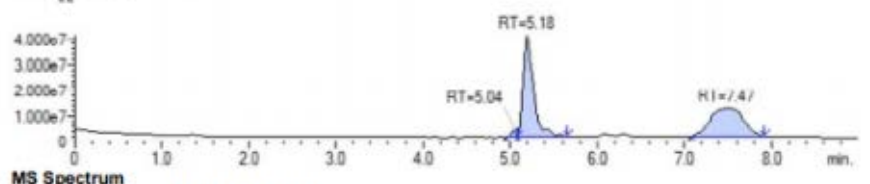

Grouplin - PDA Peak. 10, RT: 5.03 to 8.99 min

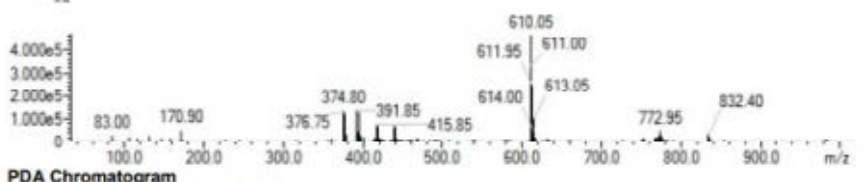

PDA Chromatogram
1: Wavelength $254 \mathrm{~nm}$, Band Width $4 \mathrm{~nm}$

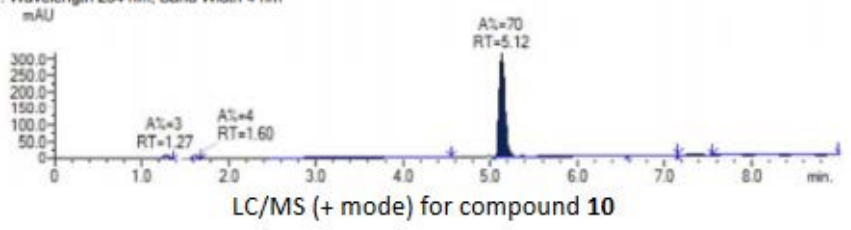

LC/MS (+ mode) for compound 10 

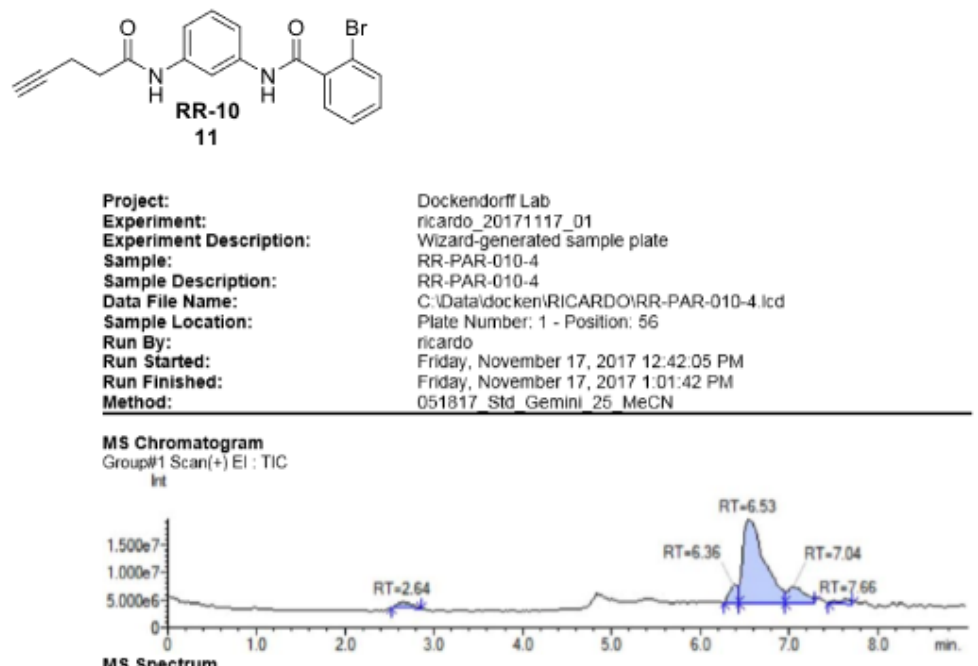

Groupt 1-PDA Peak 9, RT: 6.33 to $8.98 \mathrm{~min}$

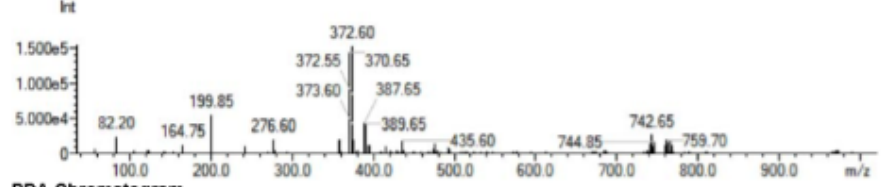

PDA Chromatogram

Wavelength $254 \mathrm{~nm}$, Band Width $4 \mathrm{~nm}$

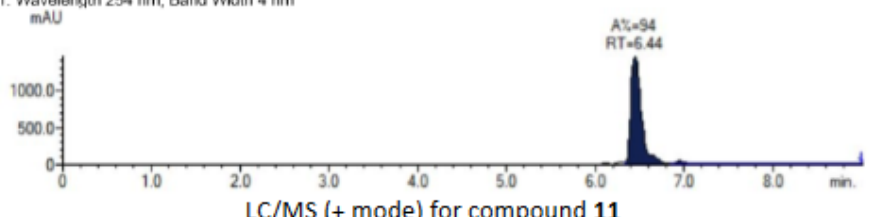

LC/MS (+ mode) for compound 11

LC/MS (+ mode) for compound 11 


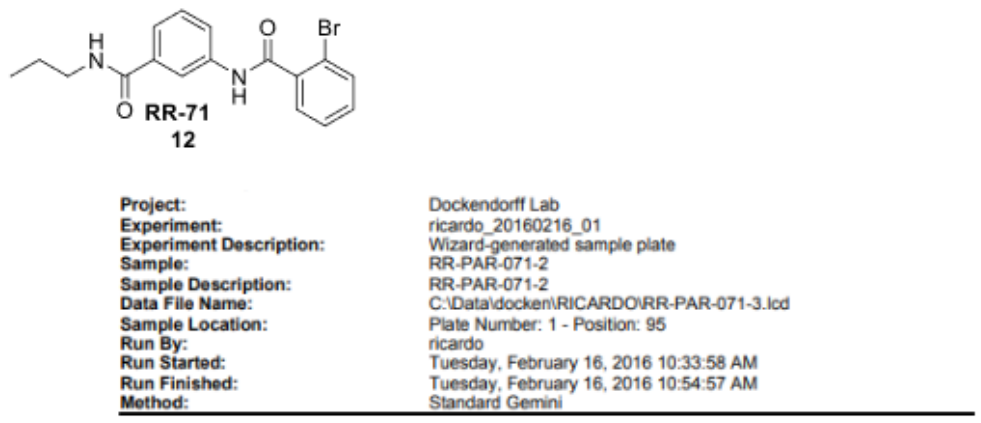

MS Chromatogram
Grouptit Scan $(*)$ El : TIC

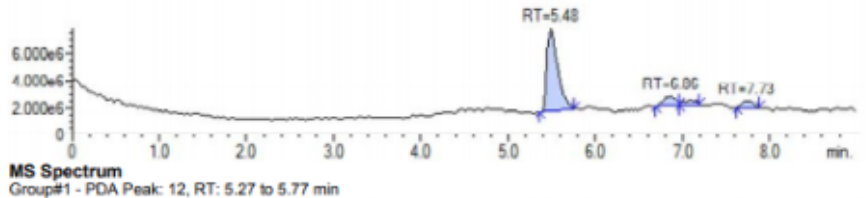

MS Spectrum
Group I - PDA Peak: 12, RT: 5.27 to $5.77 \mathrm{~min}$
int

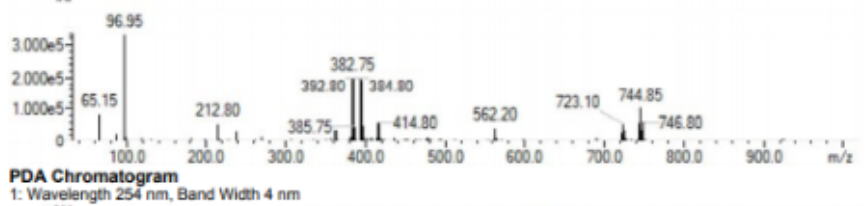

t: Wavelength $254 \mathrm{~nm}$, Band With $4 \mathrm{~nm}$

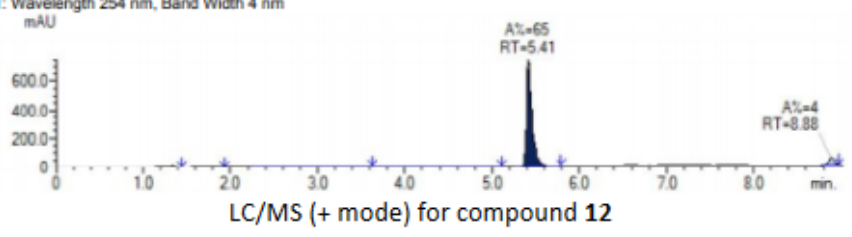

LC/MS (+ mode) for compound 12
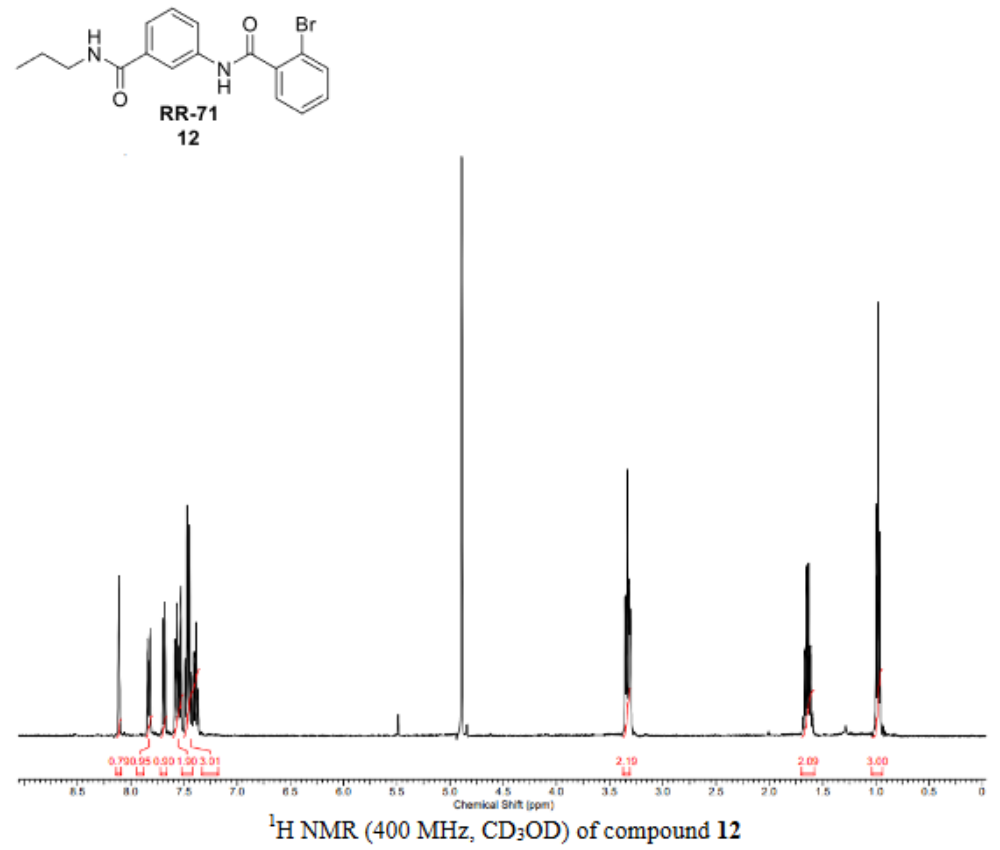

${ }^{1} \mathrm{H}$ NMR (400 MHz, CD ${ }_{3} \mathrm{OD}$ ) of compound 12 
<smiles>COCCC(=O)Nc1cccc(NC(=O)c2ccccc2Br)c1</smiles>

13

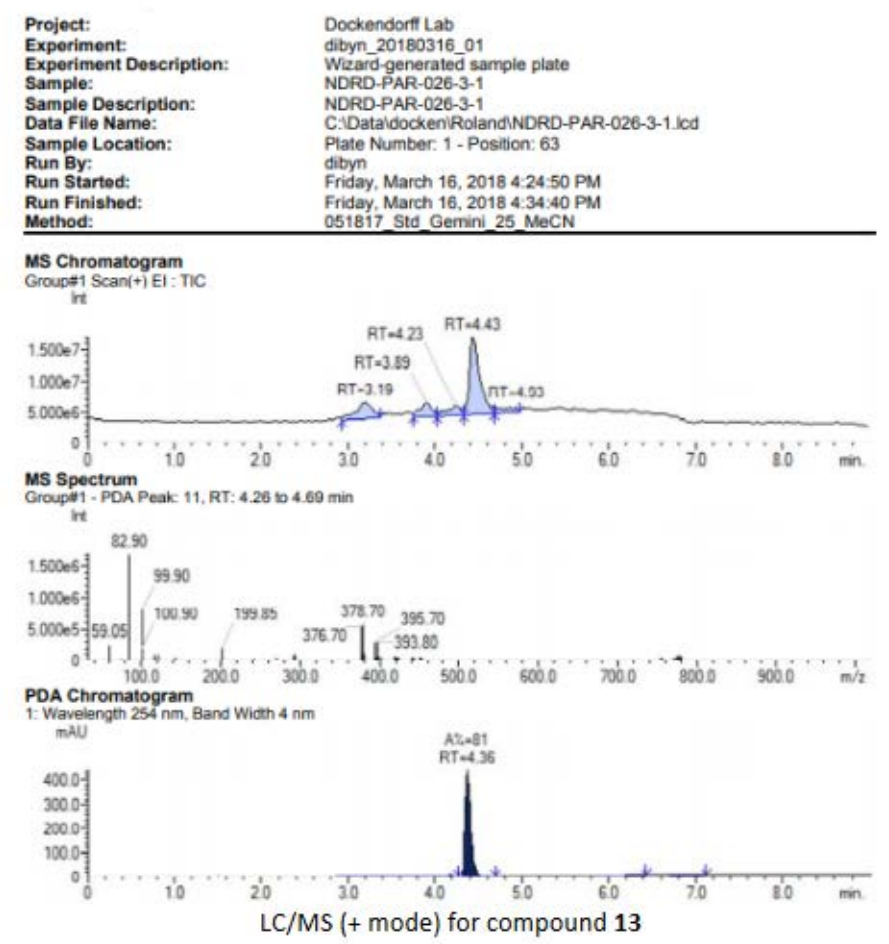

LC/MS (+ mode) for compound 13
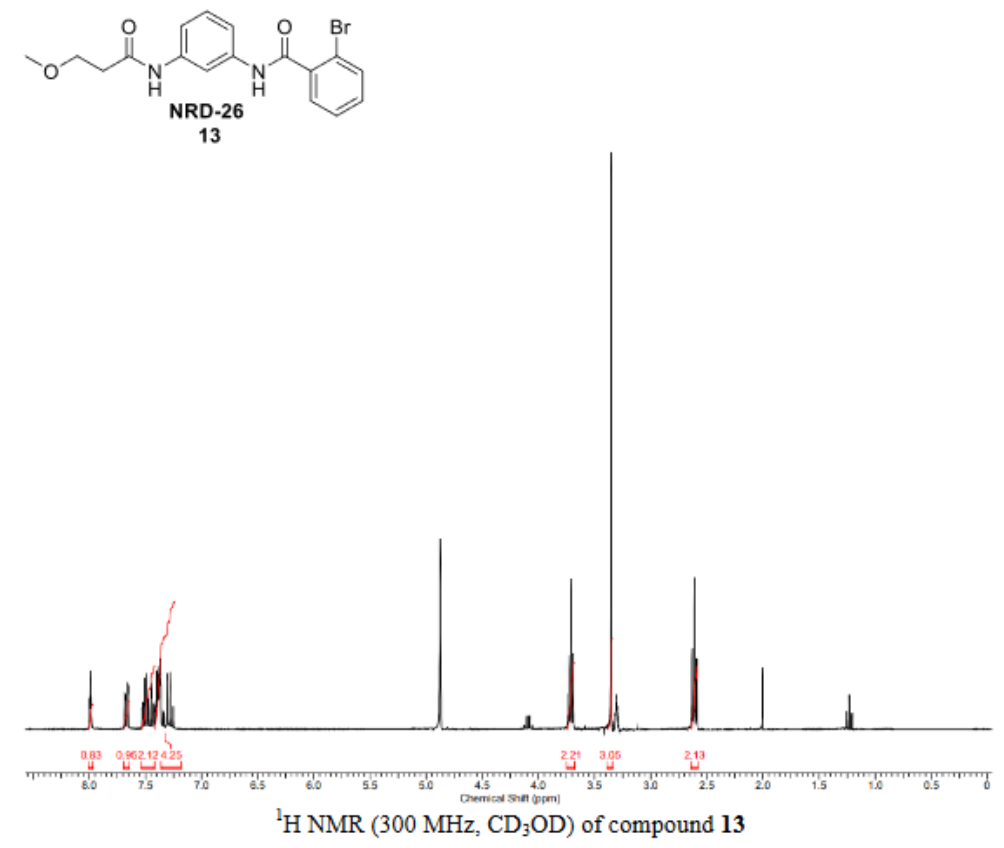

${ }^{1} \mathrm{H}$ NMR (300 MHz, CD ${ }_{3} \mathrm{OD}$ ) of compound 13 


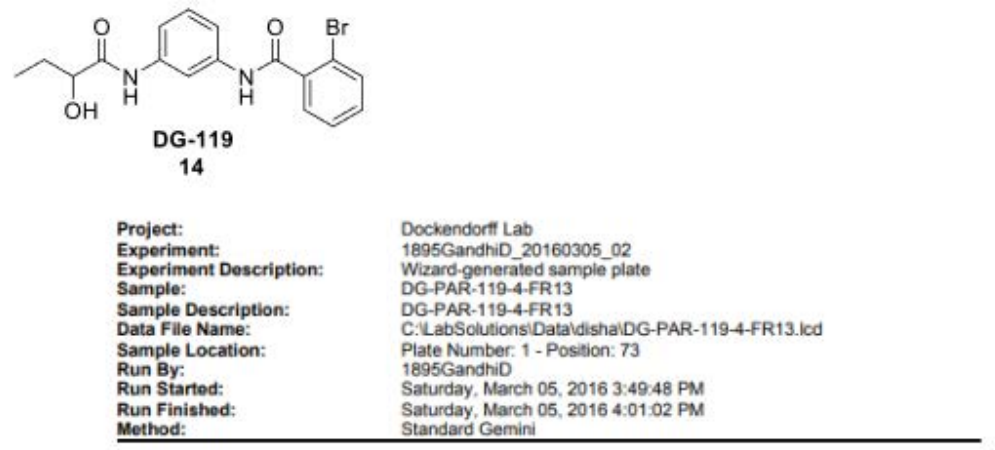

MS Chromatogram

Group

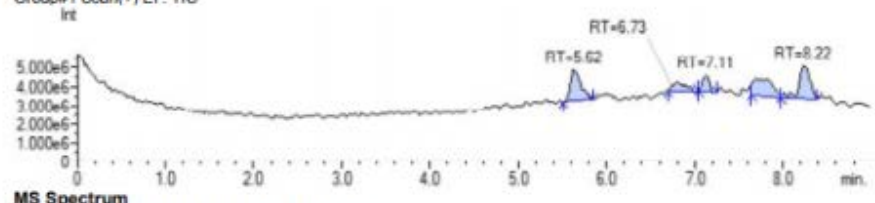

Grouppett - PDA Peak: 15, RT: 5.34 to 5.79 min

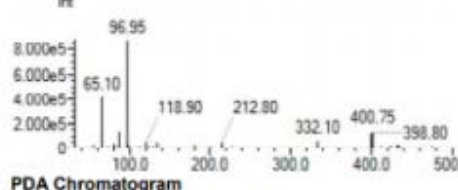

PDA Chromatogram
1. Wavelength $254 \mathrm{~nm}$. Band With $4 \mathrm{~nm}$

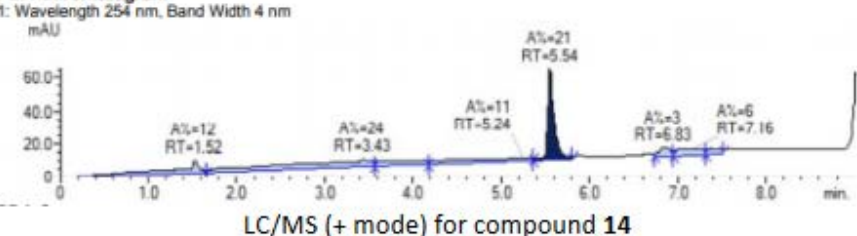

LC/MS (+ mode) for compound 14
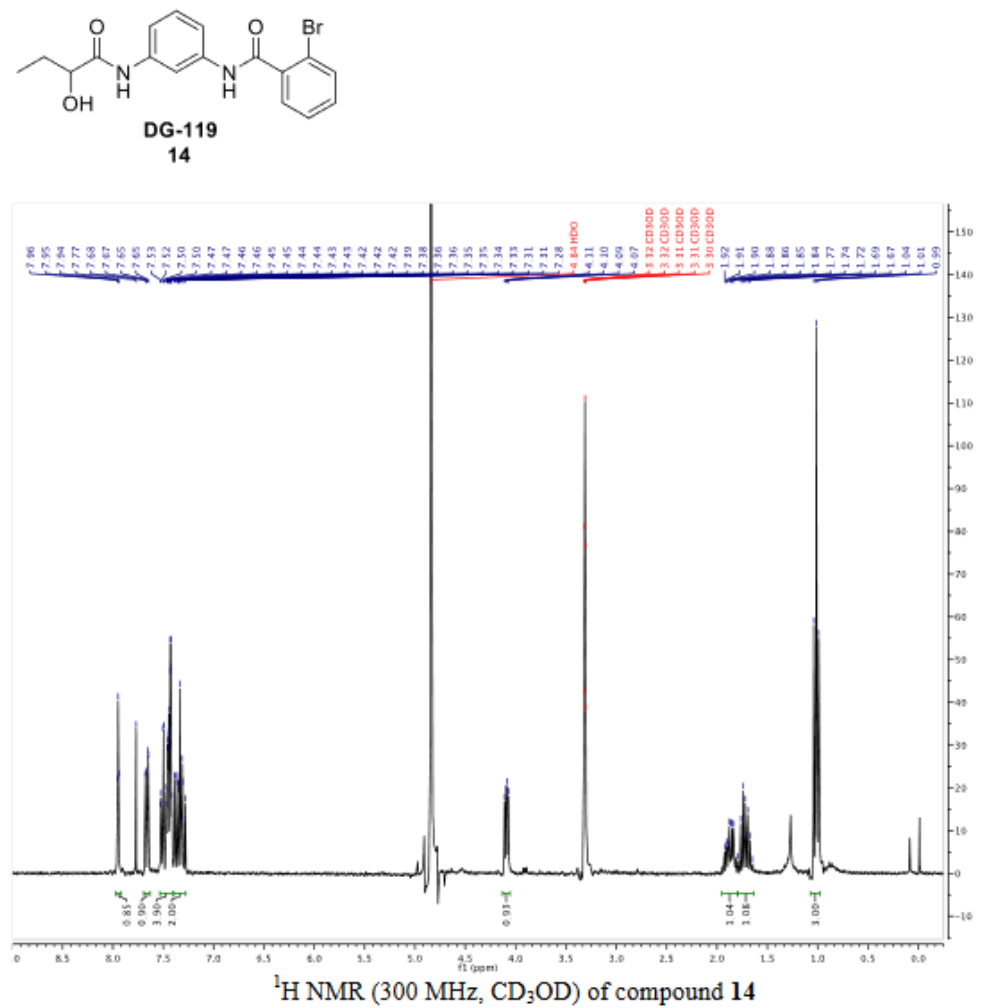

${ }^{1} \mathrm{H}$ NMR (300 MHz, CD ${ }_{3} \mathrm{OD}$ ) of compound 14 


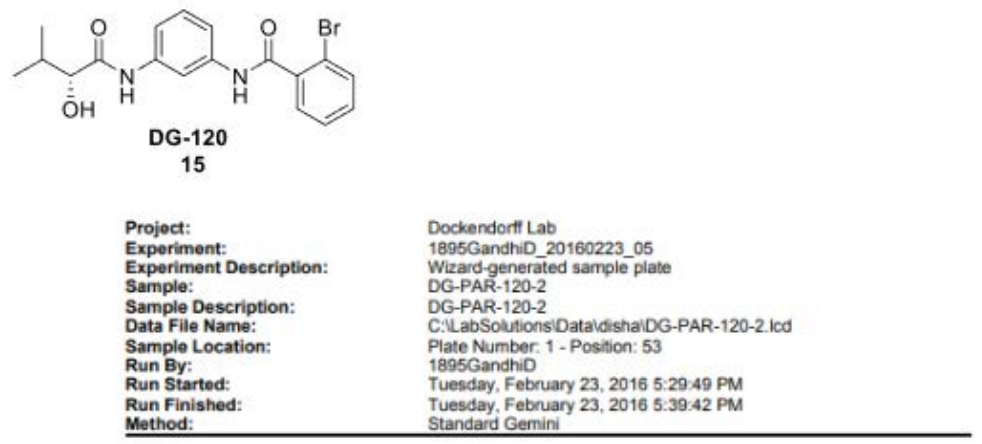

MS Chromatogram
Groudet Scan(+) EI : TIC

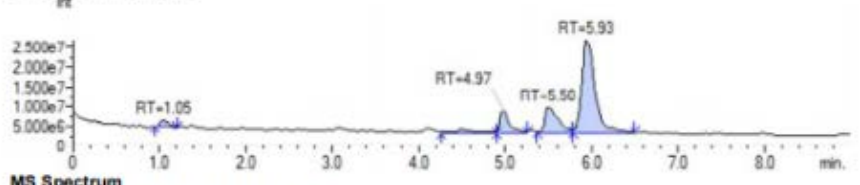

MS Spectrum

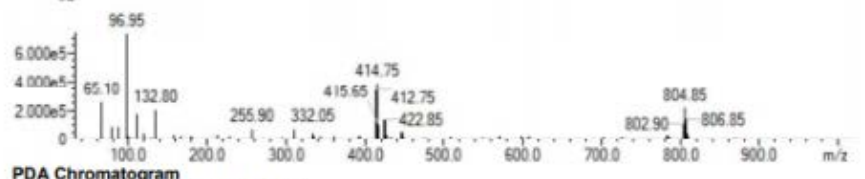

1: Wavelengath $254 \mathrm{~nm}$, Band Width $4 \mathrm{~nm}$

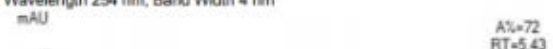

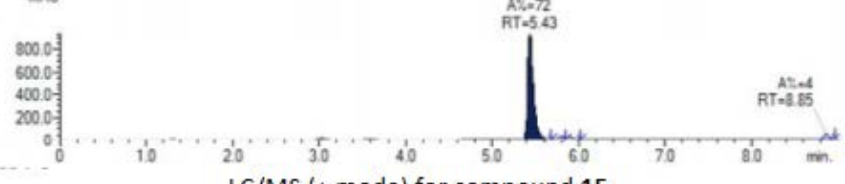

LC/MS (+ mode) for compound 15

LC/MS (+ mode) for compound 15

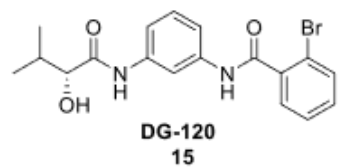

15

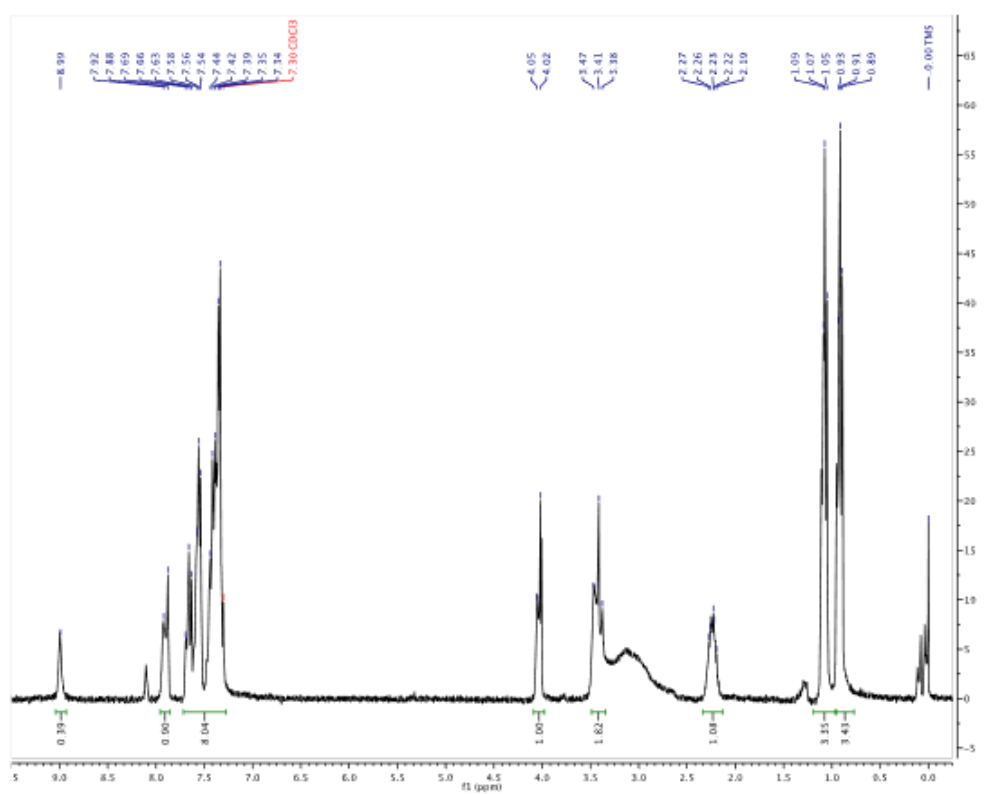

${ }^{1} \mathrm{H} \mathrm{NMR}\left(300 \mathrm{MHz}, \mathrm{CDCl}_{3}\right.$ ) of compound 15 
${ }^{1} \mathrm{H}$ NMR (300 MHz, $\mathrm{CDCl}_{3}$ ) of compound 15

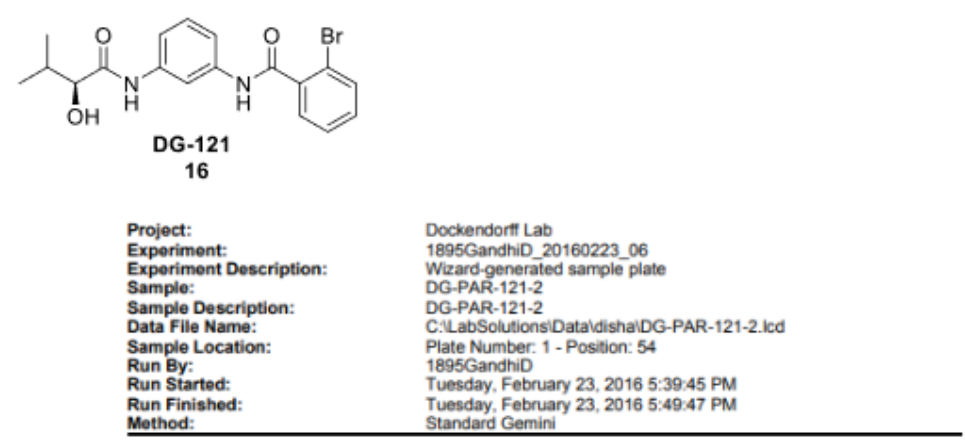

MS Chromatogram
Group:1 Scan(+) El : TIC

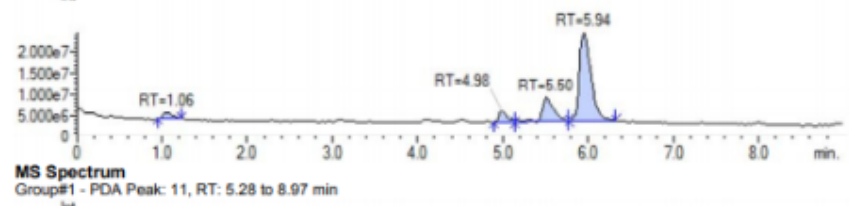

Groupt 1 - PDA Peak 11, RT: 5.28 to 8.97 min

PDA Chromatogram 2000 PDA Chromatogram
1: Wavelength $254 \mathrm{~nm}$, Band Width $4 \mathrm{~nm}$

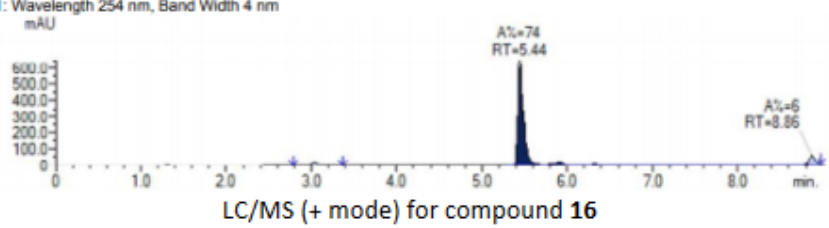

LC/MS (+ mode) for compound 16

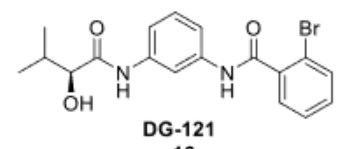

16

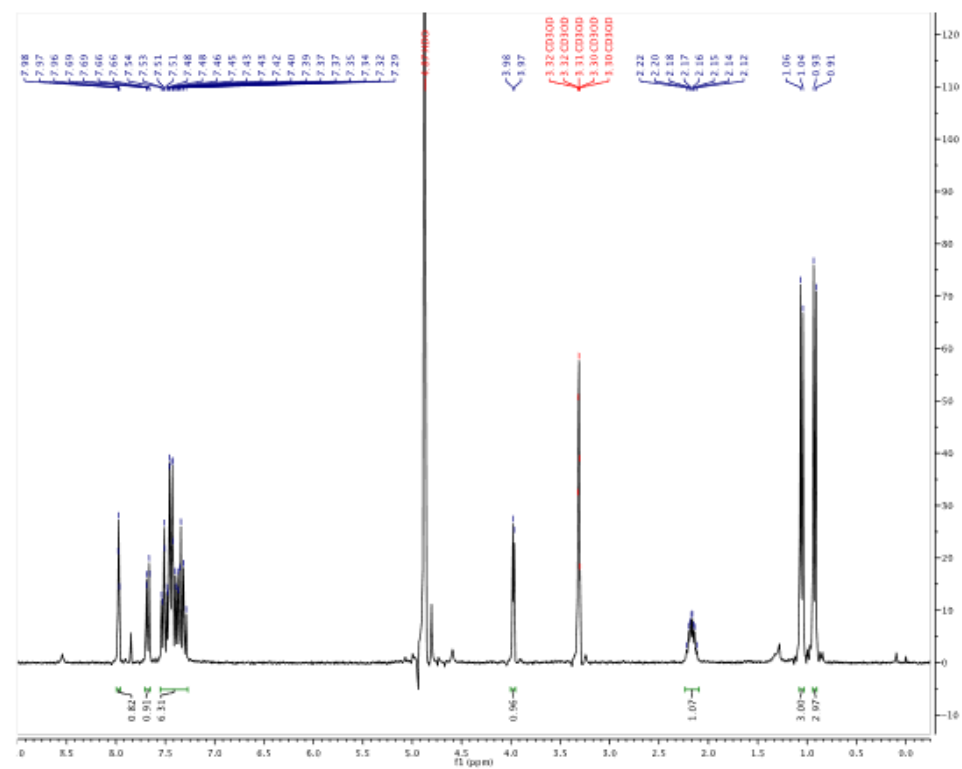

${ }^{1} \mathrm{H}$ NMR (300 MHz, CD $\left.{ }_{3} \mathrm{OD}\right)$ of compound 16 
${ }^{1} \mathrm{H}$ NMR (300 MHz, CD3OD) of compound 16

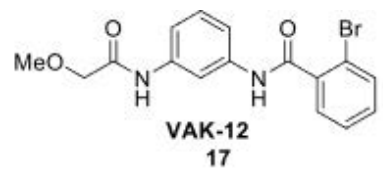

\begin{tabular}{|c|c|}
\hline $\begin{array}{l}\text { Project: } \\
\text { Experiment: } \\
\text { Experiment Description: } \\
\text { Sample: } \\
\text { Sample Description: } \\
\text { Data File Name: } \\
\text { Sample Location: } \\
\text { Run By: } \\
\text { Run Started: } \\
\text { Run Finished: } \\
\text { Mothod: }\end{array}$ & 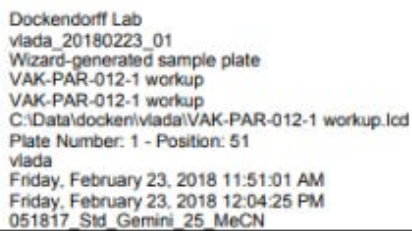 \\
\hline
\end{tabular}

MS Chromatogram

Grouple1 Scan(*) EI : TIC

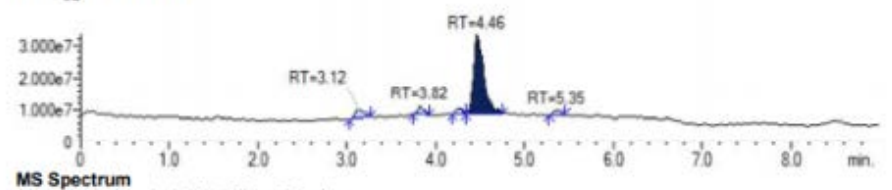

Groupt1 - MS Peak: 4, RT: 4.33 to $4.75 \mathrm{~min}$

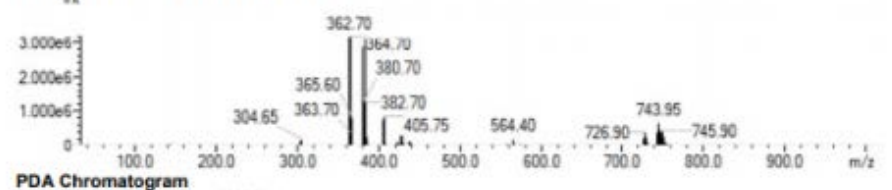

1: Waveiength $254 \mathrm{~nm}$, Band Widh $4 \mathrm{~nm}$

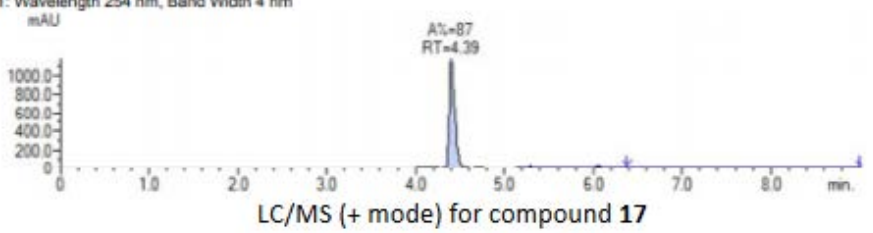

LC/MS (+ mode) for compound 17 


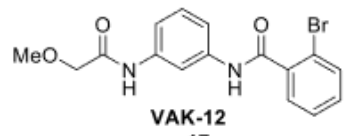

17

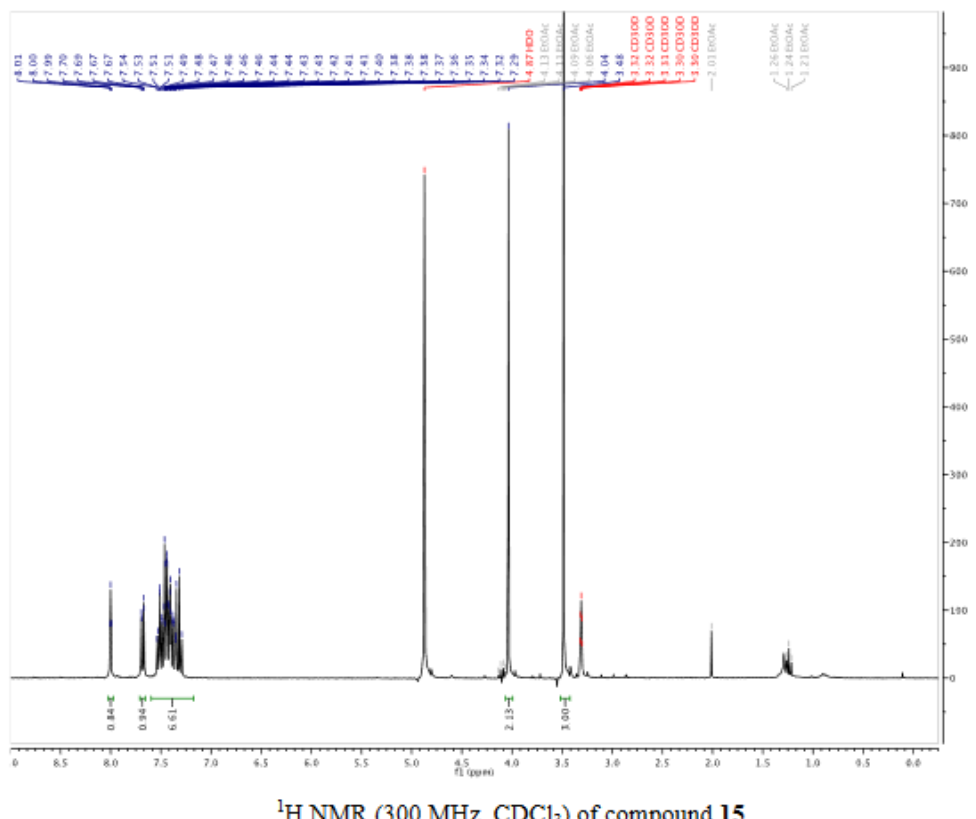

${ }^{1} \mathrm{H}$ NMR (300 MHz, $\mathrm{CDCl}_{3}$ ) of compound 15
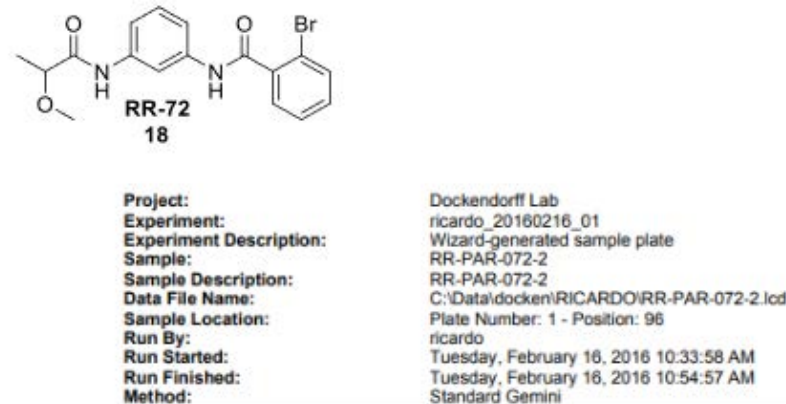

Run Finis

Slandard Gemini

MS Chromatogram

Groudt 1 Scan(*) El : TIC

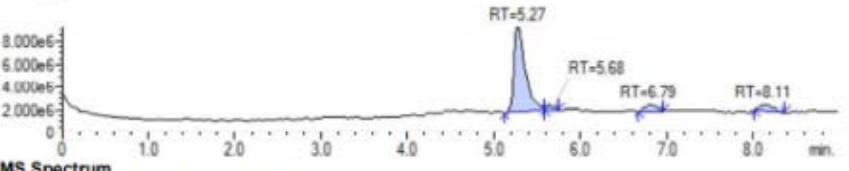

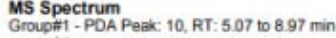

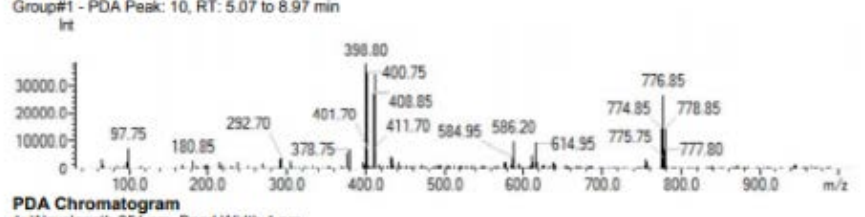

PDA Chromatogram
1: Wavelength $254 \mathrm{~nm}$, Band Width $4 \mathrm{~nm}$

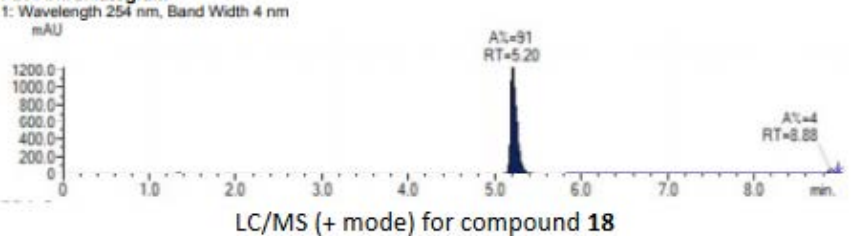

LC/MS (+ mode) for compound 18

LC/MS (+ mode) for compound 18 

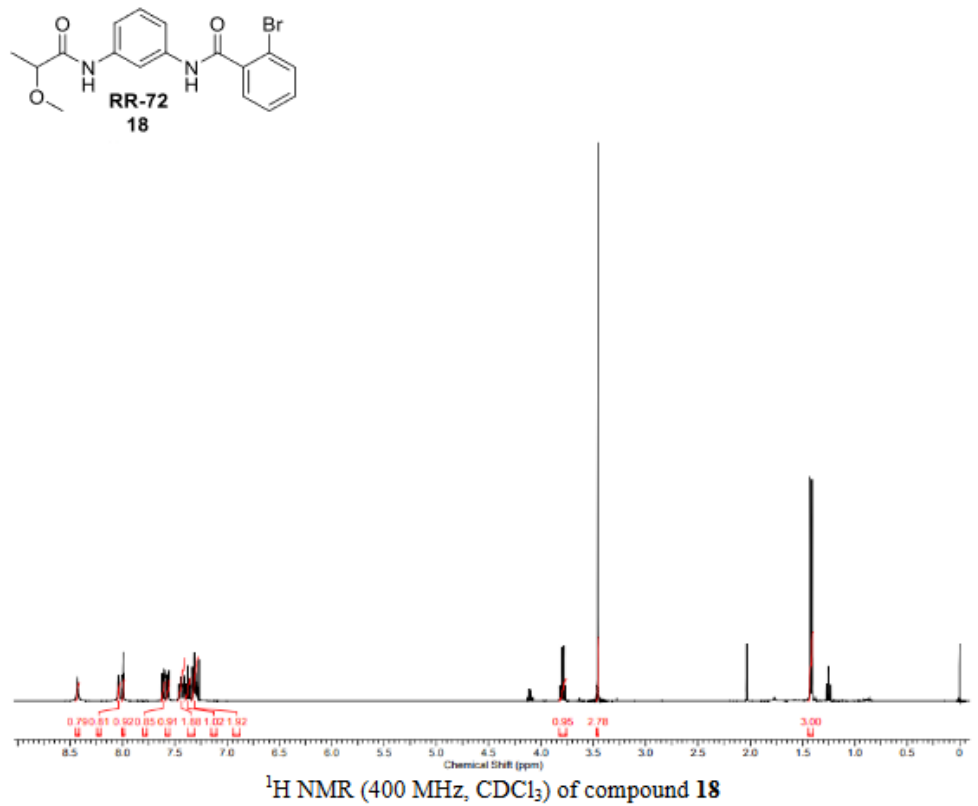

${ }^{1} \mathrm{H}$ NMR (400 MHz, $\mathrm{CDCl}_{3}$ ) of compound 18

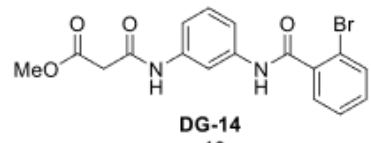

19

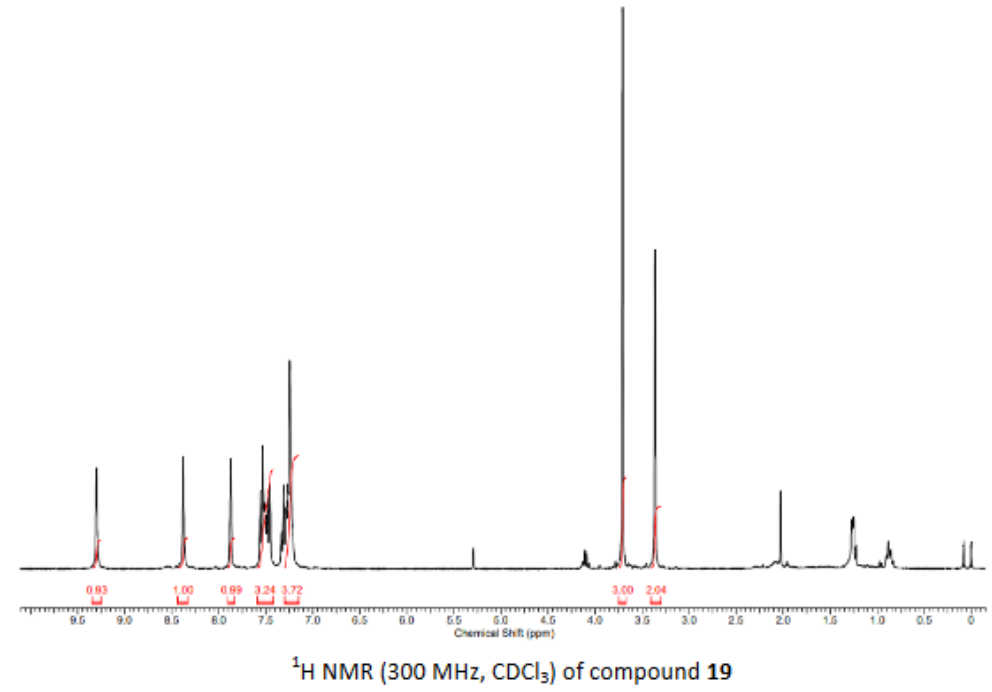

1H NMR (300 MHz, $\mathrm{CDCl}_{3}$ ) of compound 19 

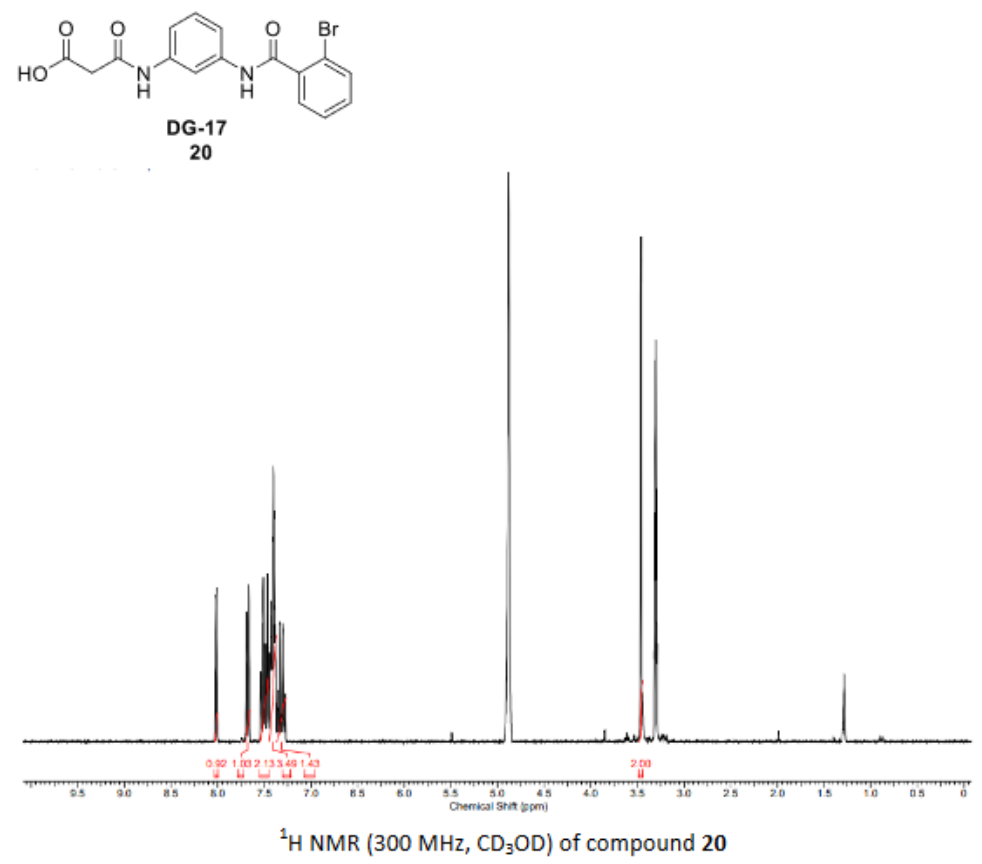

${ }^{1} \mathrm{H}$ NMR (300 MHz, CD ${ }_{3} \mathrm{OD}$ ) of compound 20

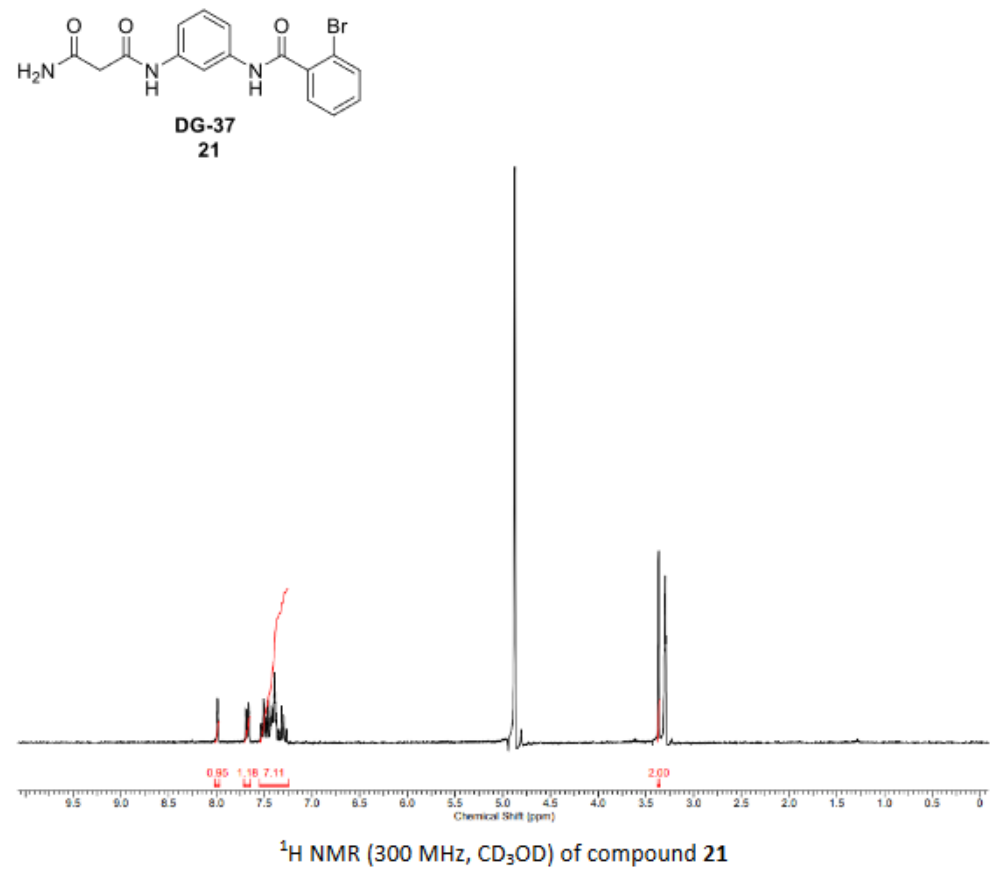

${ }^{1} \mathrm{H}$ NMR (300 MHz, CD ${ }_{3} \mathrm{OD}$ ) of compound 21 


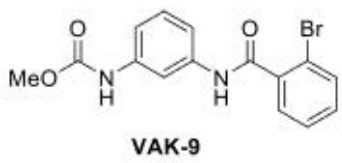

22

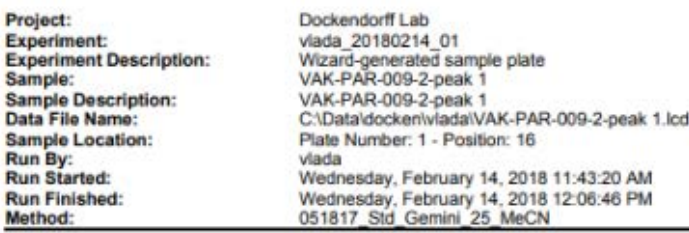

Project:

Experiment: $\quad$ Vada_20180214_01 01 pription:

WAK-PAR-009-2-peak 1

VAK-PAR $009-2$ peak 1

C.DataldockeniviadaiVAK-PAR-009-2-peak $1 . \mathrm{lod}$

Sample Location:

Run By:

Plate Number: 1 - Position: 16

Run Started:

Vlada

Wednesday, February 14, 2018 11:43:20 AM

Wednesday, February 14, 20181206.46 PM

Run Finished:
Method: 51817 Sid Gemini 25 MeC

MS Chromatogram

Groupt Scan( + EI EI : ThC

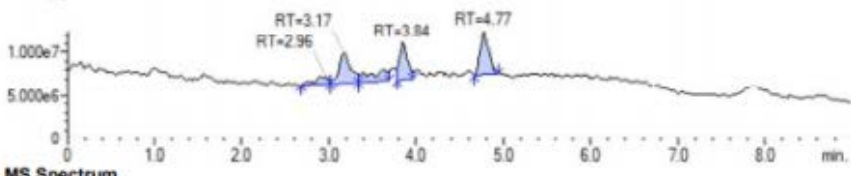

MS Spectrum

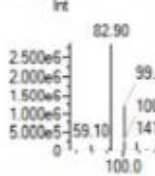

2290

$19990-10090-450$

DA Chromatogram $2000^{\circ} 300^{\circ}$

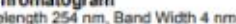

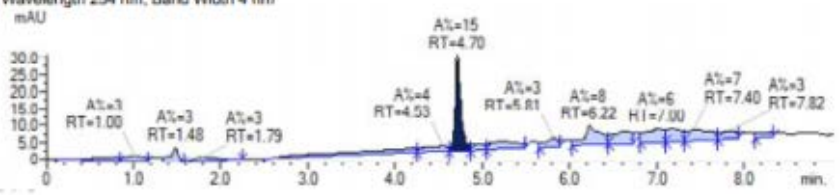

LC/MS (+ mode) for compound 22

\section{LC/MS (+ mode) for compound 22}
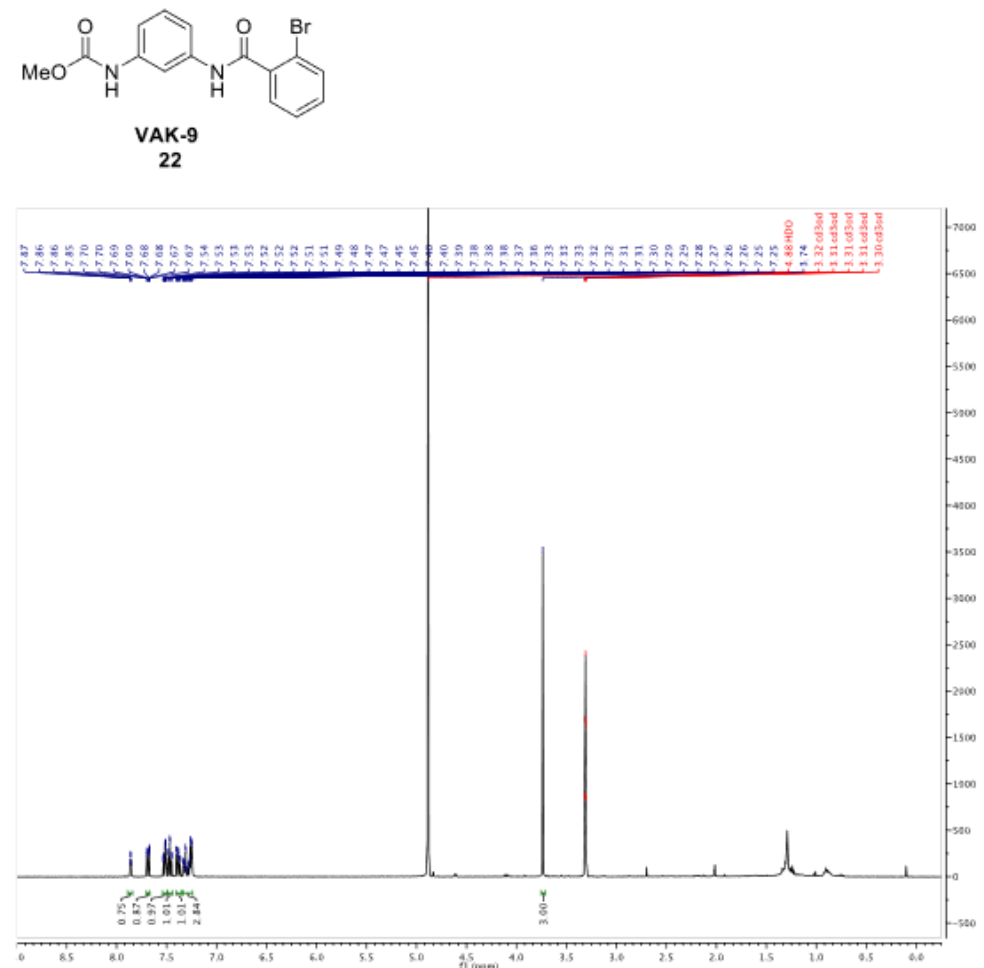

${ }^{1} \mathrm{H}$ NMR (400 MHz, CD $3 \mathrm{OD}$ ) of compound 22 
${ }^{1} \mathrm{H}$ NMR (400 MHz, CD3OD) of compound 22

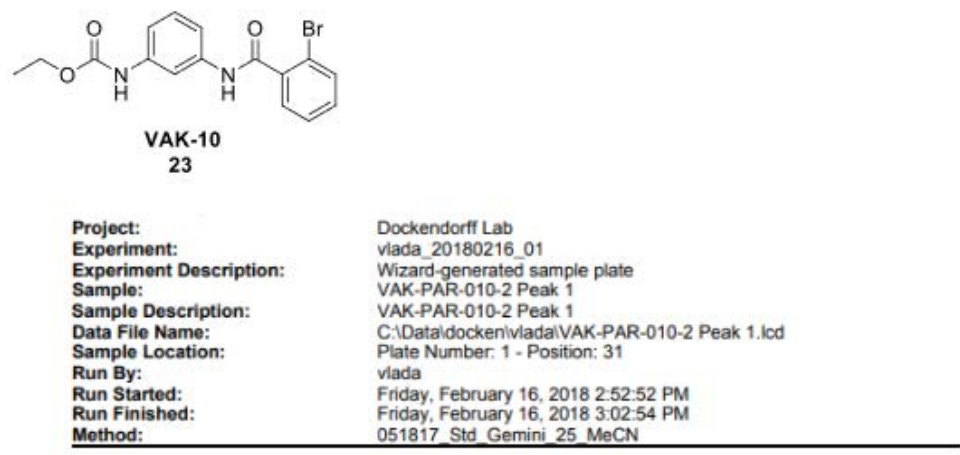

MS Chromatogram

Groupt 1 Scan(+) El : TIC

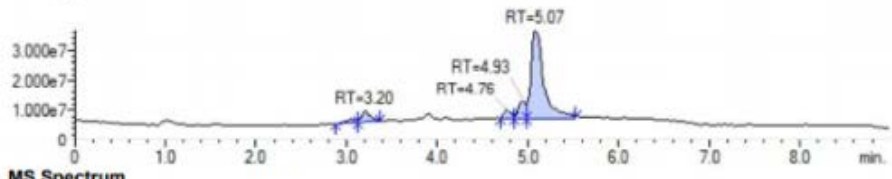

Group\#1 - PDA Peak 11, RT: 4.94 to $8.93 \mathrm{~min}$

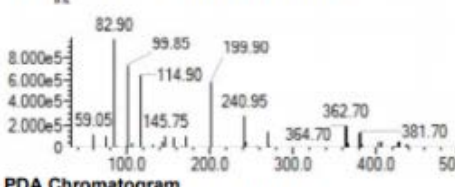

PDA Chromatogram

1: Wavelenoth $254 \mathrm{~nm}$, Band Width $4 \mathrm{~nm}$

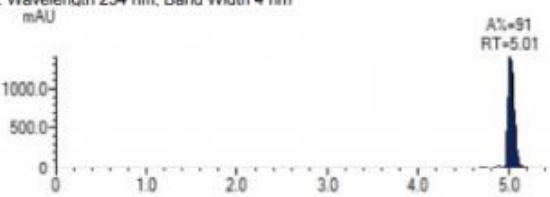

$6000^{\circ} 7000^{\circ} 8000^{\circ}+9000^{\circ} \cdots \mathrm{m} / \mathrm{s}$

LC/MS (+ mode) for compound 23

LC/MS (+ mode) for compound 23 


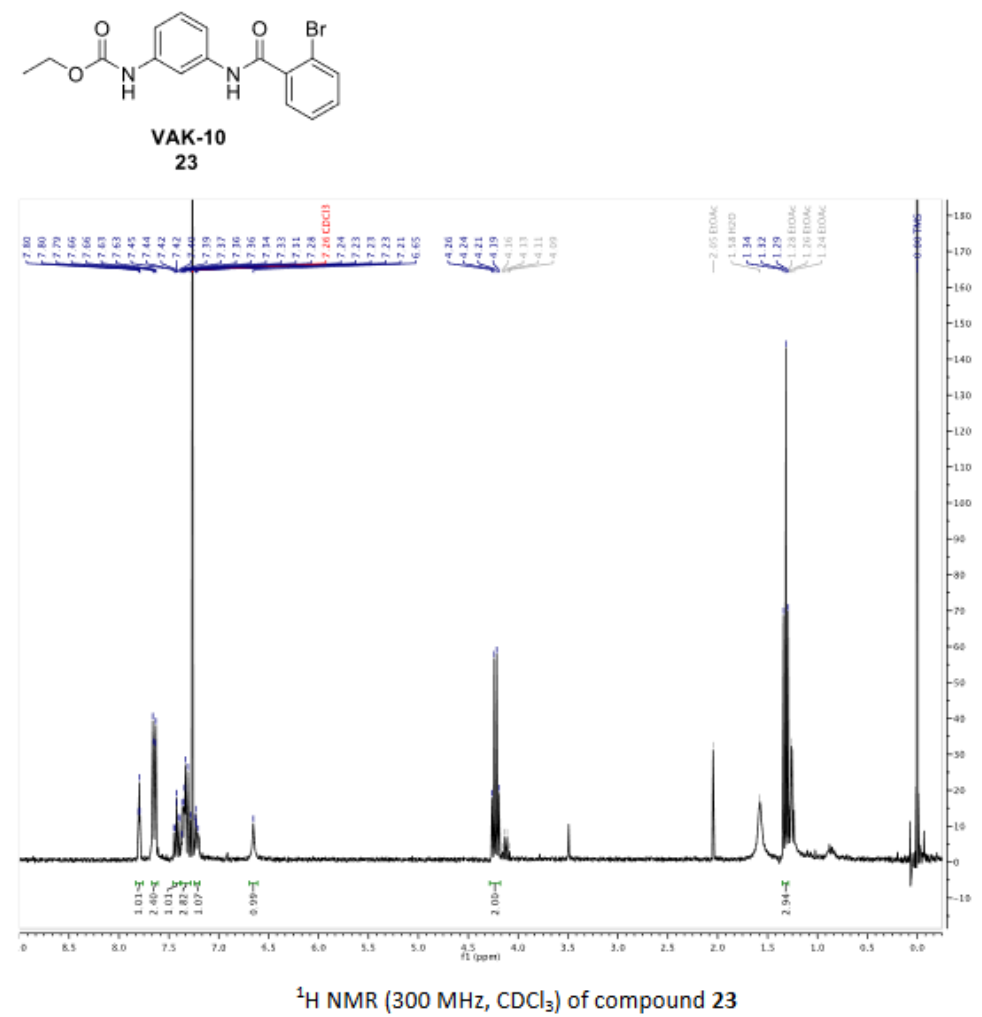

${ }^{1} \mathrm{H}$ NMR (300 MHz, $\mathrm{CDCl}_{3}$ ) of compound 23

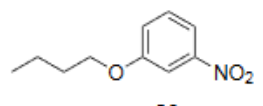

S6

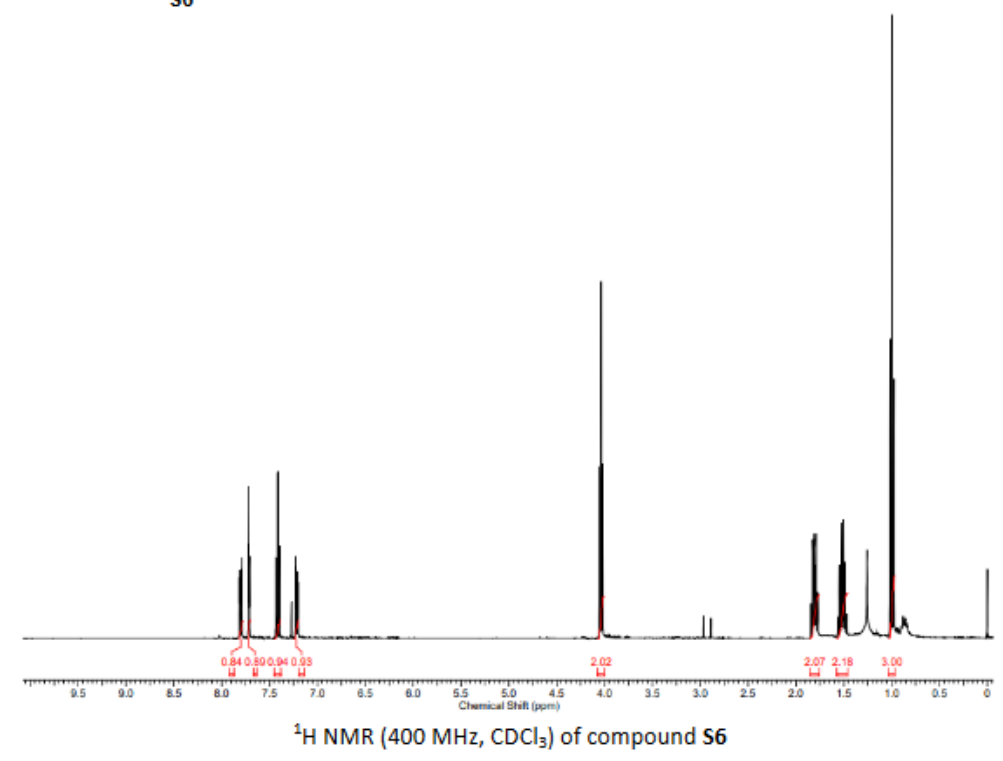

${ }^{1} \mathrm{H}$ NMR (400 MHz, $\mathrm{CDCl}_{3}$ ) of compound $\mathbf{S 6}$ 


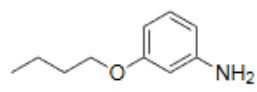

s7

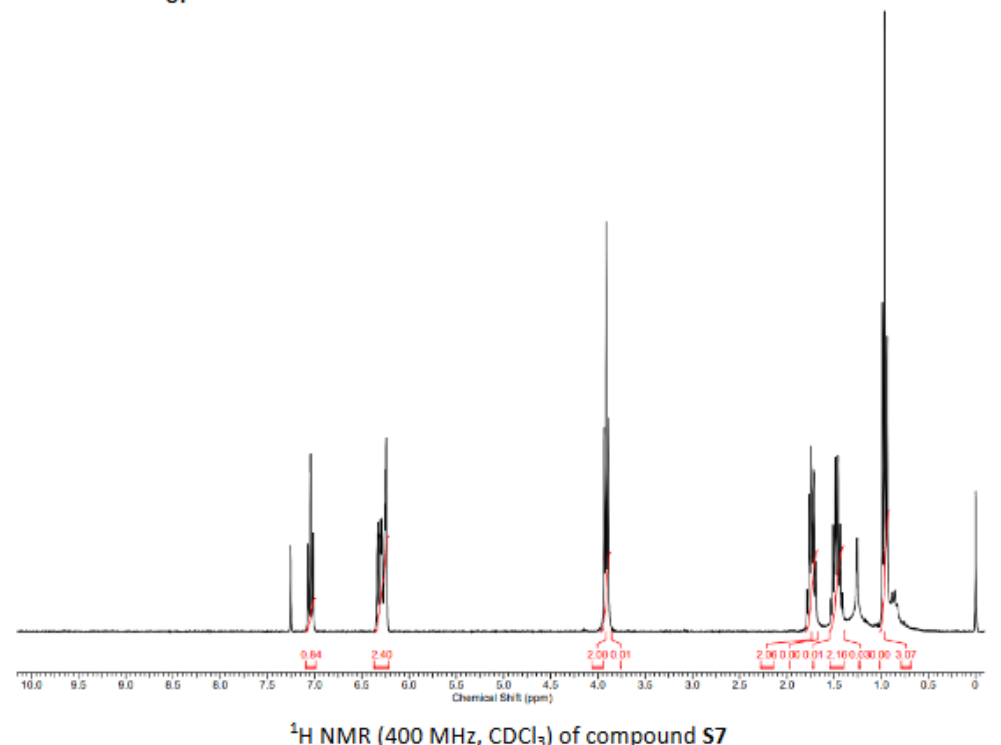

${ }^{1} \mathrm{H}$ NMR (400 MHz, $\mathrm{CDCl}_{3}$ ) of compound $\mathbf{S 7}$

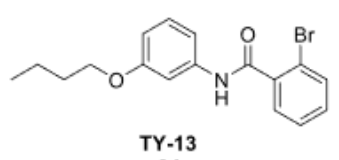

24

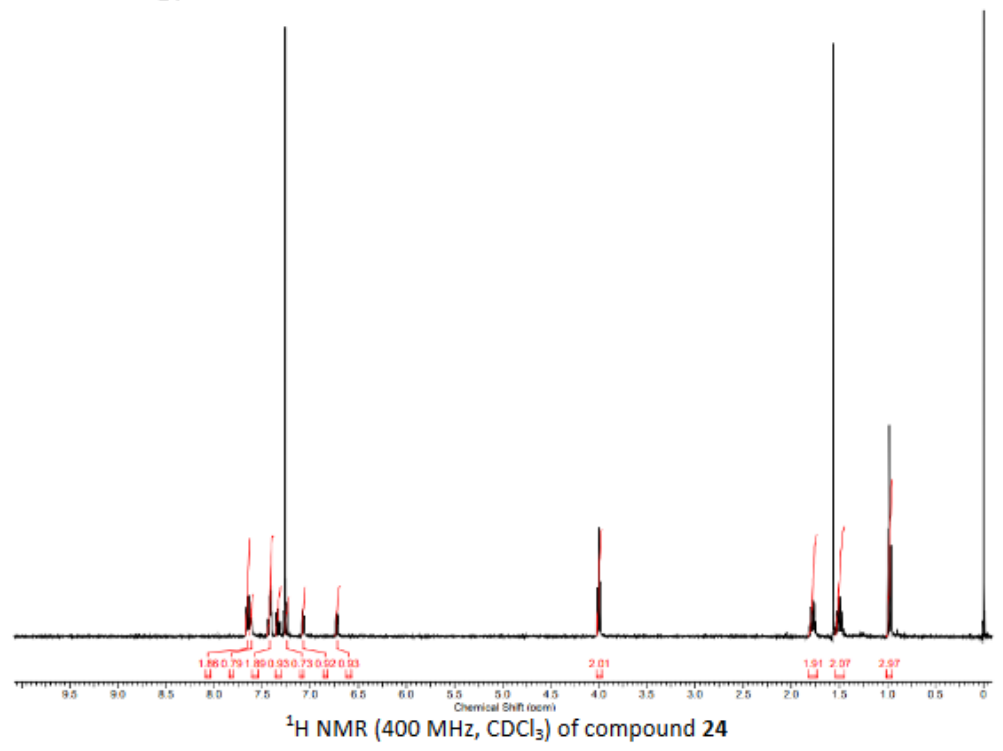

${ }^{1} \mathrm{H} \mathrm{NMR} \mathrm{(400} \mathrm{MHz,} \mathrm{CDCl}_{3}$ ) of compound 24 


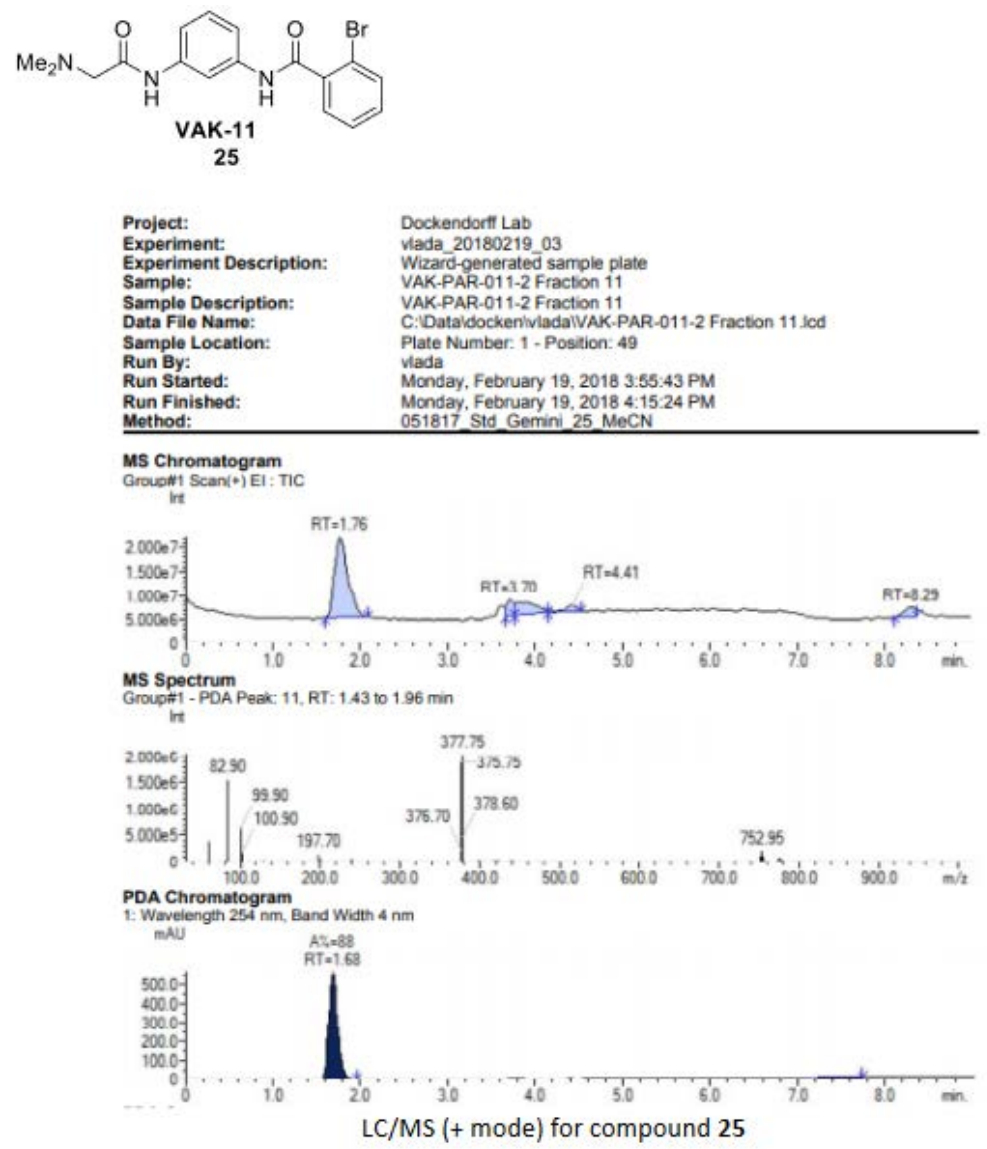

LC/MS (+ mode) for compound 25

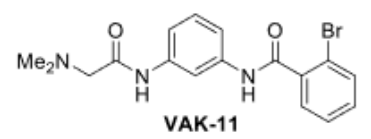

25

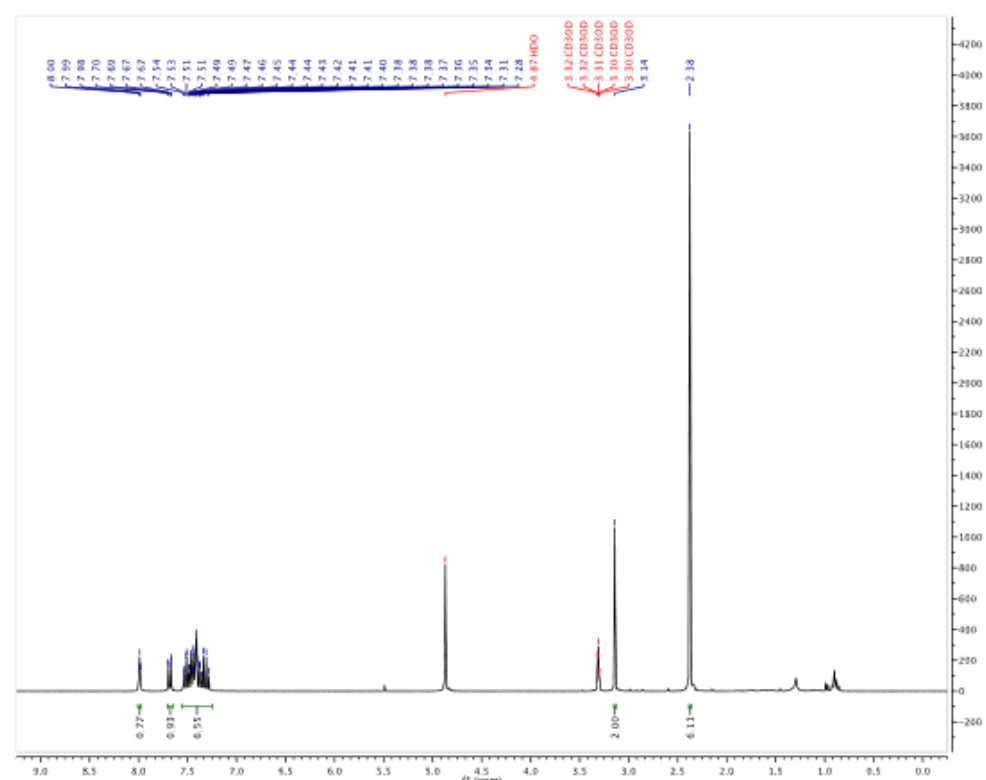

${ }^{1} \mathrm{H}$ NMR ( $300 \mathrm{MHz}, \mathrm{CDCl}_{3}$ ) of compound 25

${ }^{1} \mathrm{H} \mathrm{NMR} \mathrm{(300} \mathrm{MHz,} \mathrm{CDCl}_{3}$ ) of compound 25 


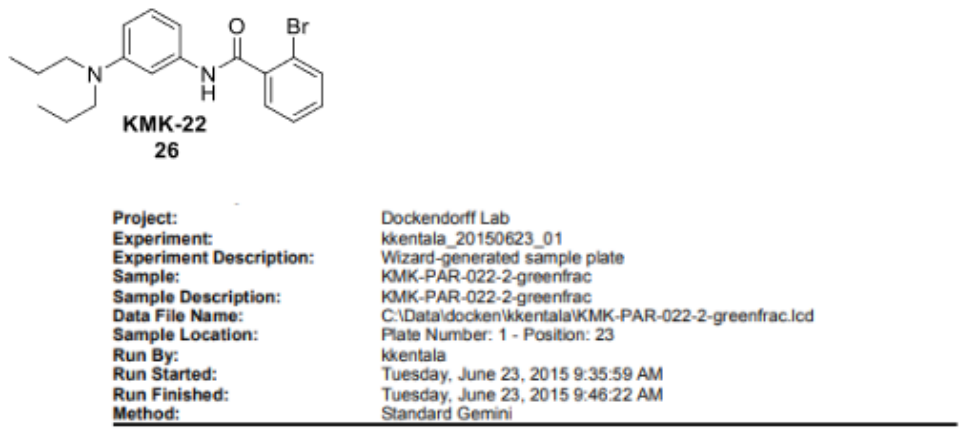
Run Finished: $\quad$ Tuesday, June 23, 2015 9:46:22 AM

MS Chromatogram

Grousill 1 Scan $(*)$ El: TIC

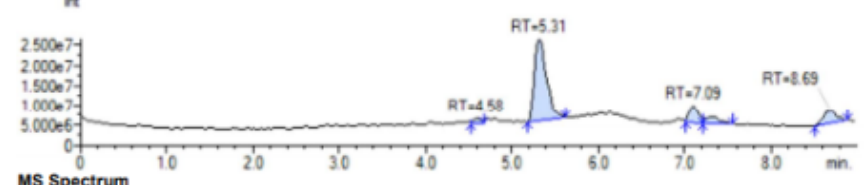

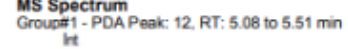

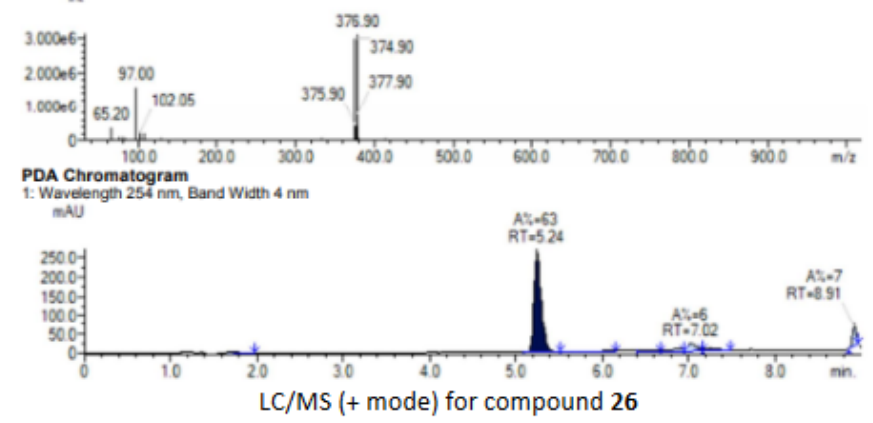

LC/MS (+ mode) for compound 26

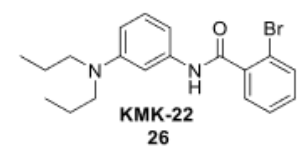

26

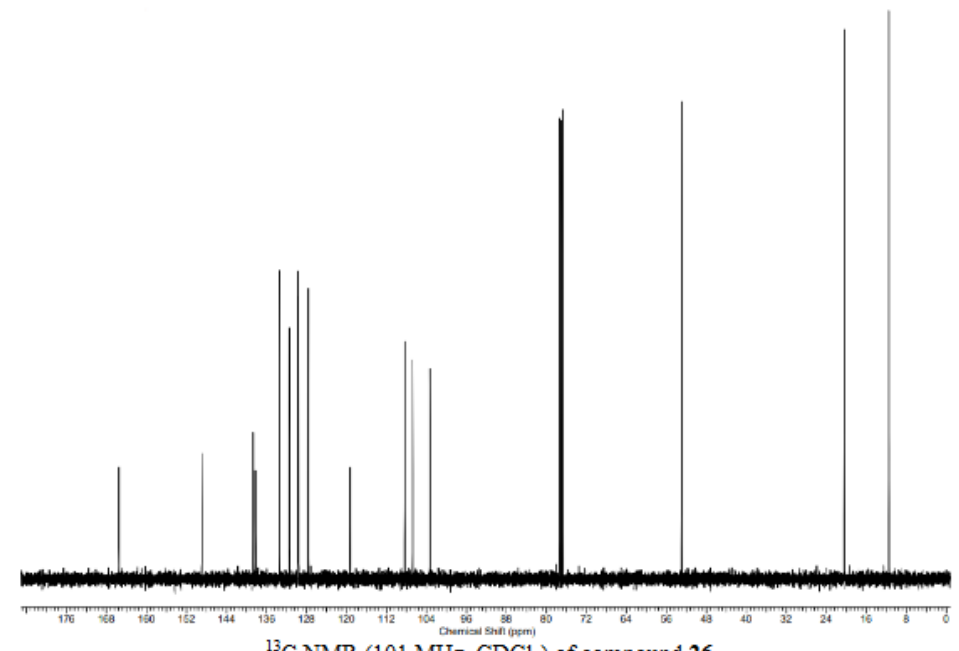

${ }^{13} \mathrm{C} \mathrm{NMR}$ (101 MHz, $\mathrm{CDCl}_{3}$ ) of compound 26

${ }^{13} \mathrm{C}$ NMR (101 MHz, CDCl 3 ) of compound 26 

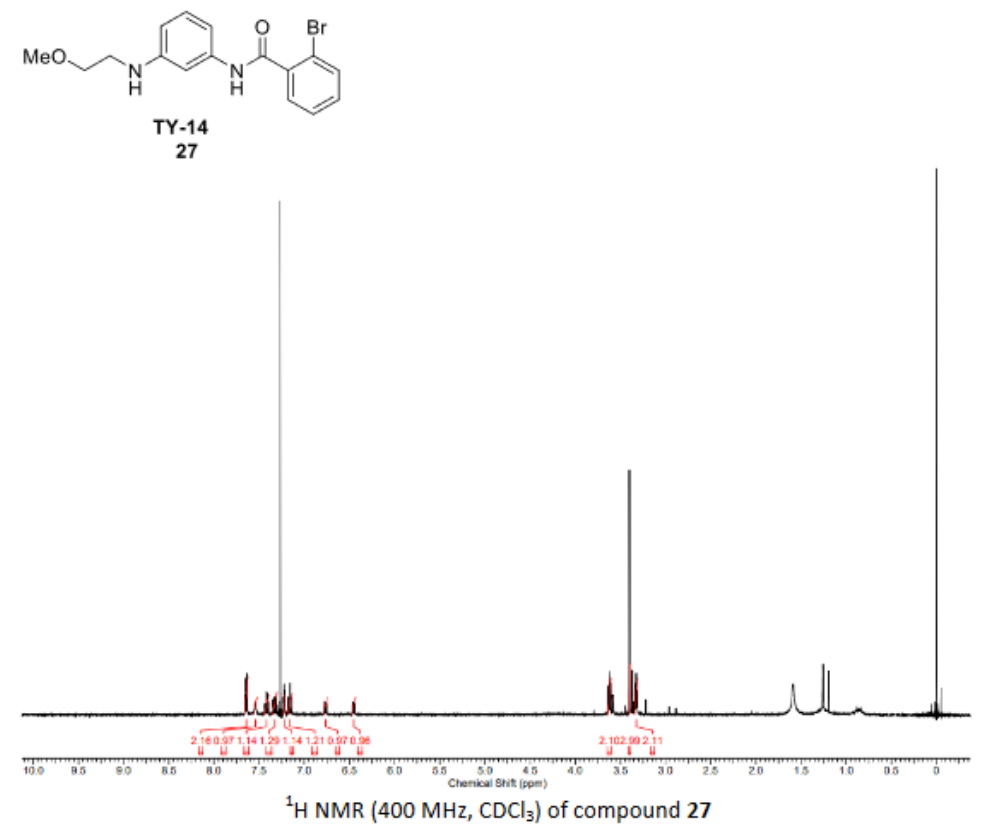

${ }^{1} \mathrm{H}$ NMR (400 MHz, $\mathrm{CDCl}_{3}$ ) of compound 27

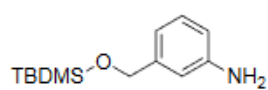

S8

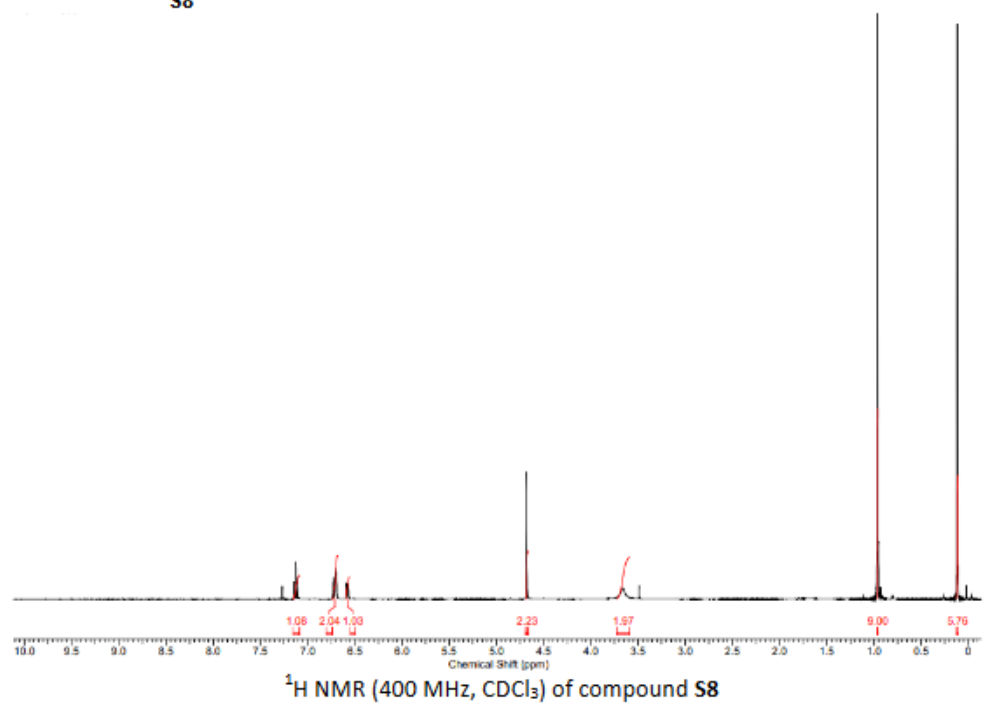

${ }^{1} \mathrm{H}$ NMR (400 MHz, $\mathrm{CDCl}_{3}$ ) of compound $\mathbf{S 8}$ 

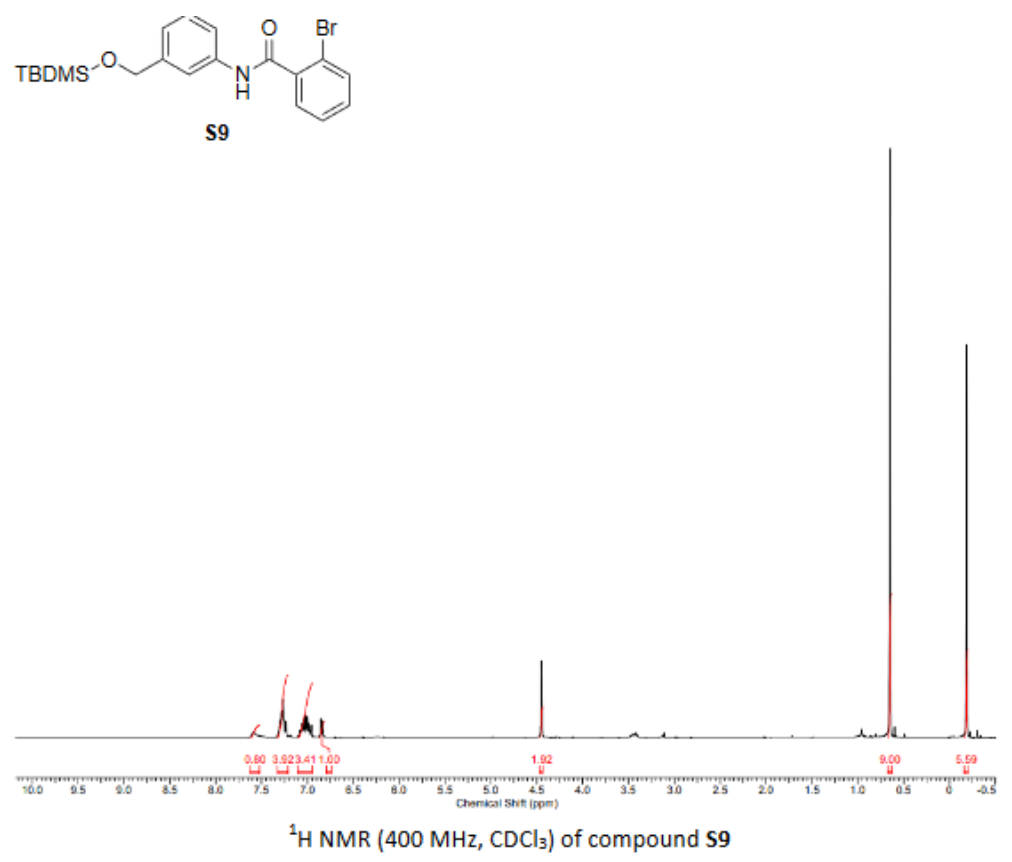

${ }^{1} \mathrm{H}$ NMR (400 MHz, $\mathrm{CDCl}_{3}$ ) of compound $\mathbf{5 9}$

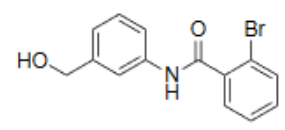

S10

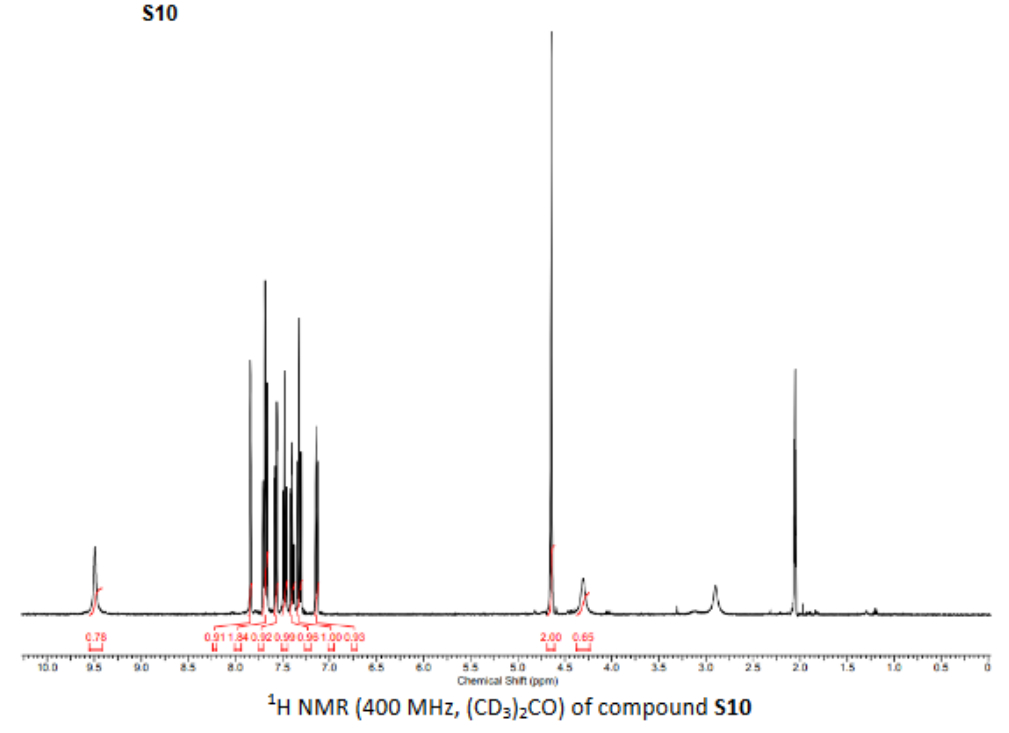

${ }^{1} \mathrm{H}$ NMR (400 MHz, $\left.\left(\mathrm{CD}_{3}\right)_{2} \mathrm{CO}\right)$ of compound $\mathbf{S 1 0}$ 

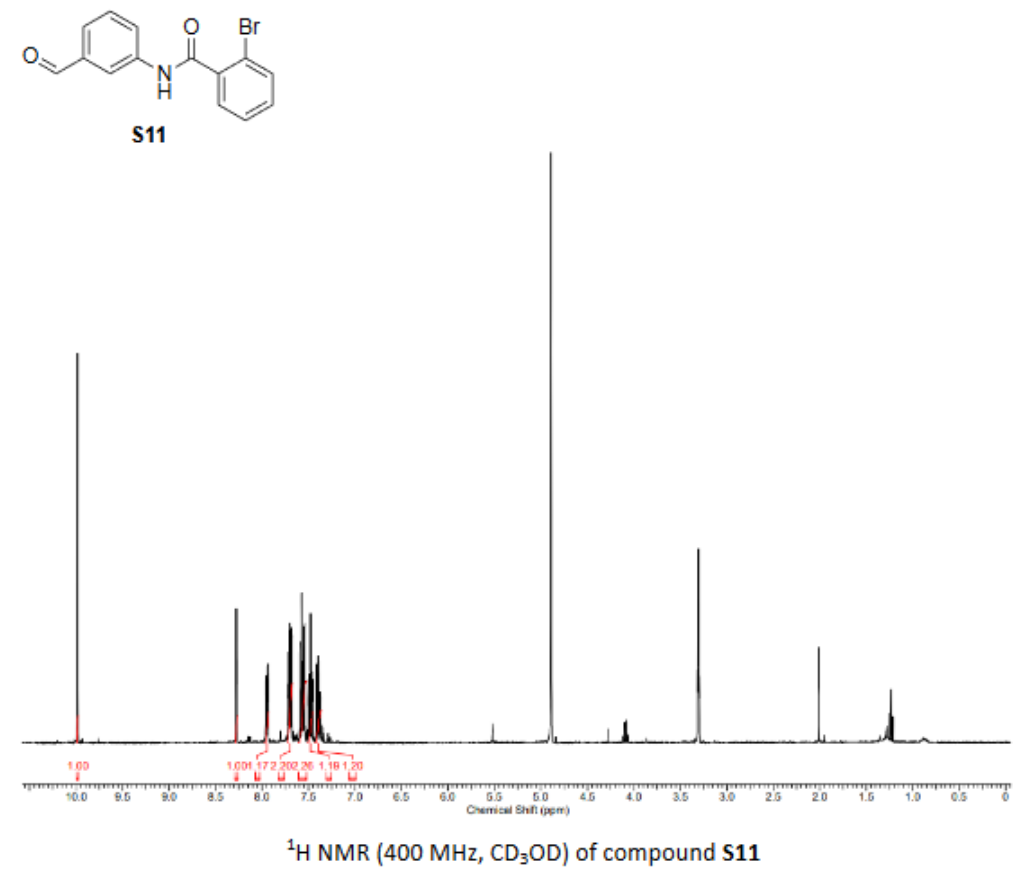

${ }^{1} \mathrm{H}$ NMR (400 MHz, CD ${ }_{3} \mathrm{OD}$ ) of compound S11
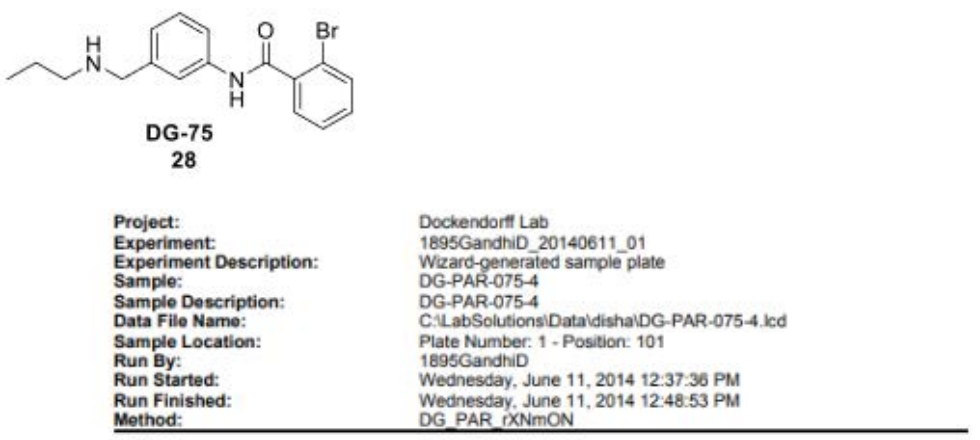

MS Chromatogram

Groupet Scan( $($ ) EI : TiC

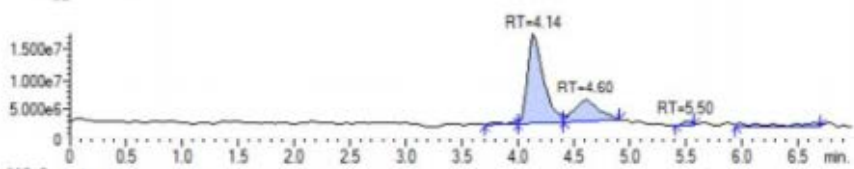

MS Spectrum
Groupt1- PDAA Peak 11, RT: 3.62 to $4.42 \mathrm{~min}$

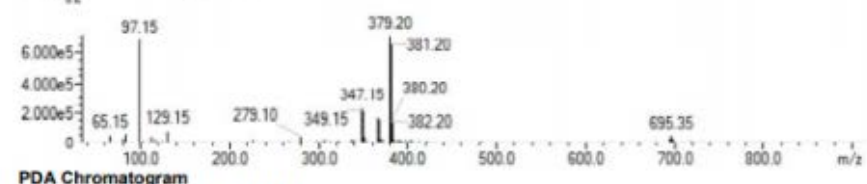

1: Waveiength $254 \mathrm{~nm}$, Band With $4 \mathrm{~nm}$

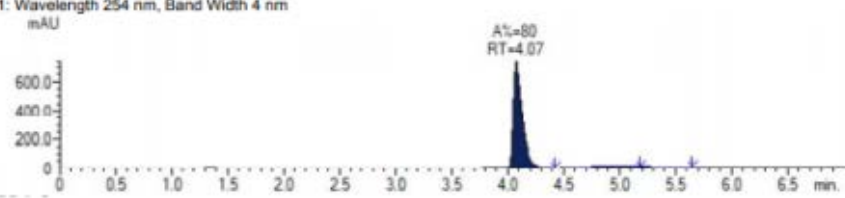

LC/MS (+ mode) for compound 28

LC/MS (+ mode) for compound $\mathbf{2 8}$ 


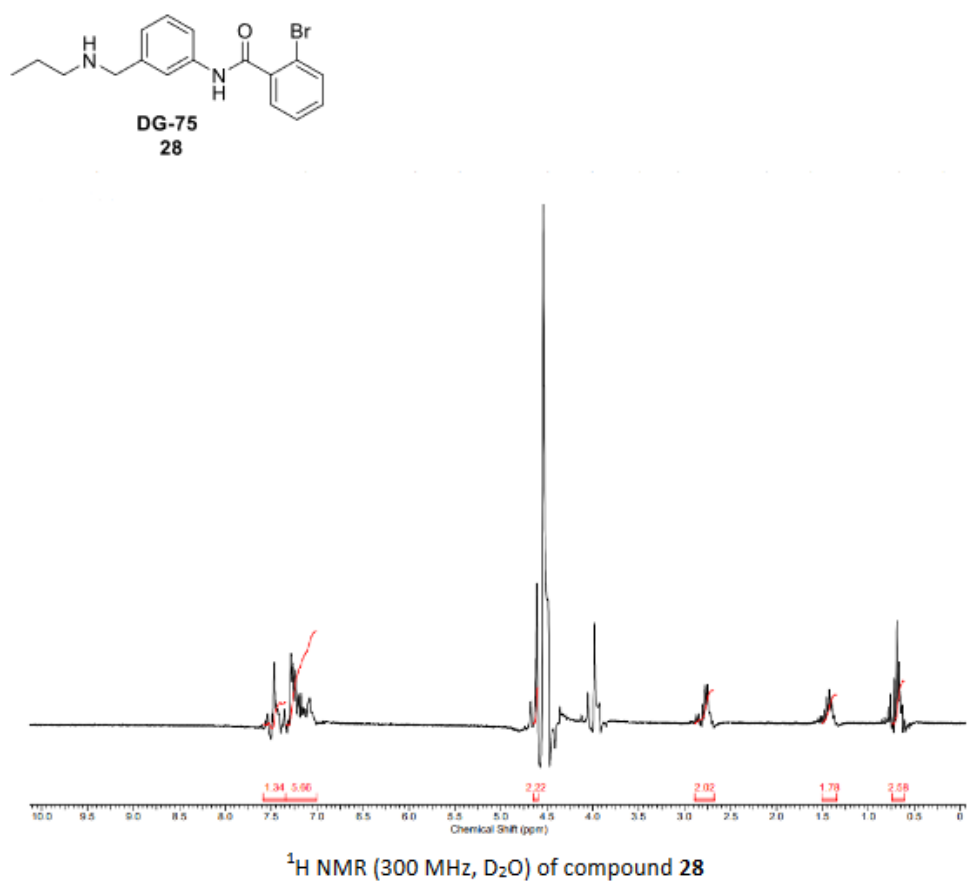

${ }^{1} \mathrm{H}$ NMR (300 MHz, $\mathrm{D}_{2} \mathrm{O}$ ) of compound 28

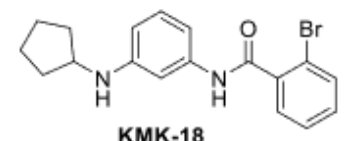

29

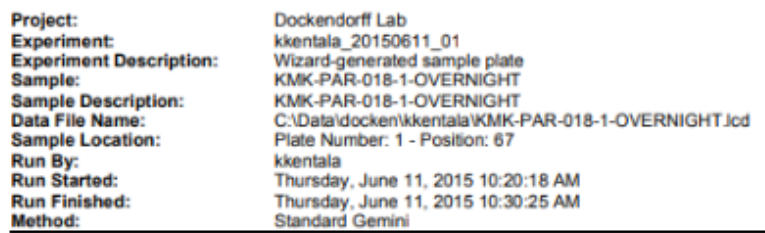

MS Chromatogram

Group: 1 Scan( + ) El: TIC

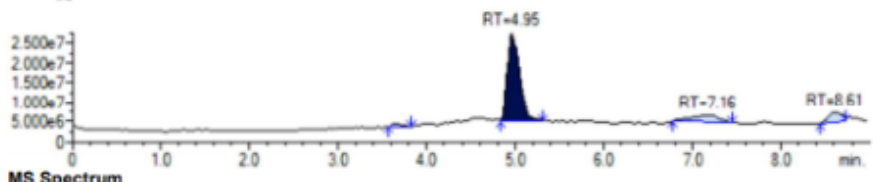

MS Spectrum

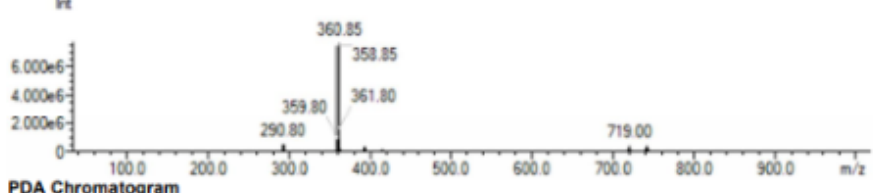

PDA Chromatogram

Wavelength $254 \mathrm{~nm}$, Band Width $4 \mathrm{~nm}$

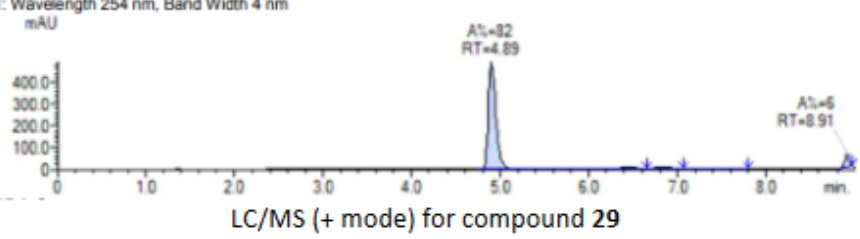

LC/MS (+ mode) for compound 29 

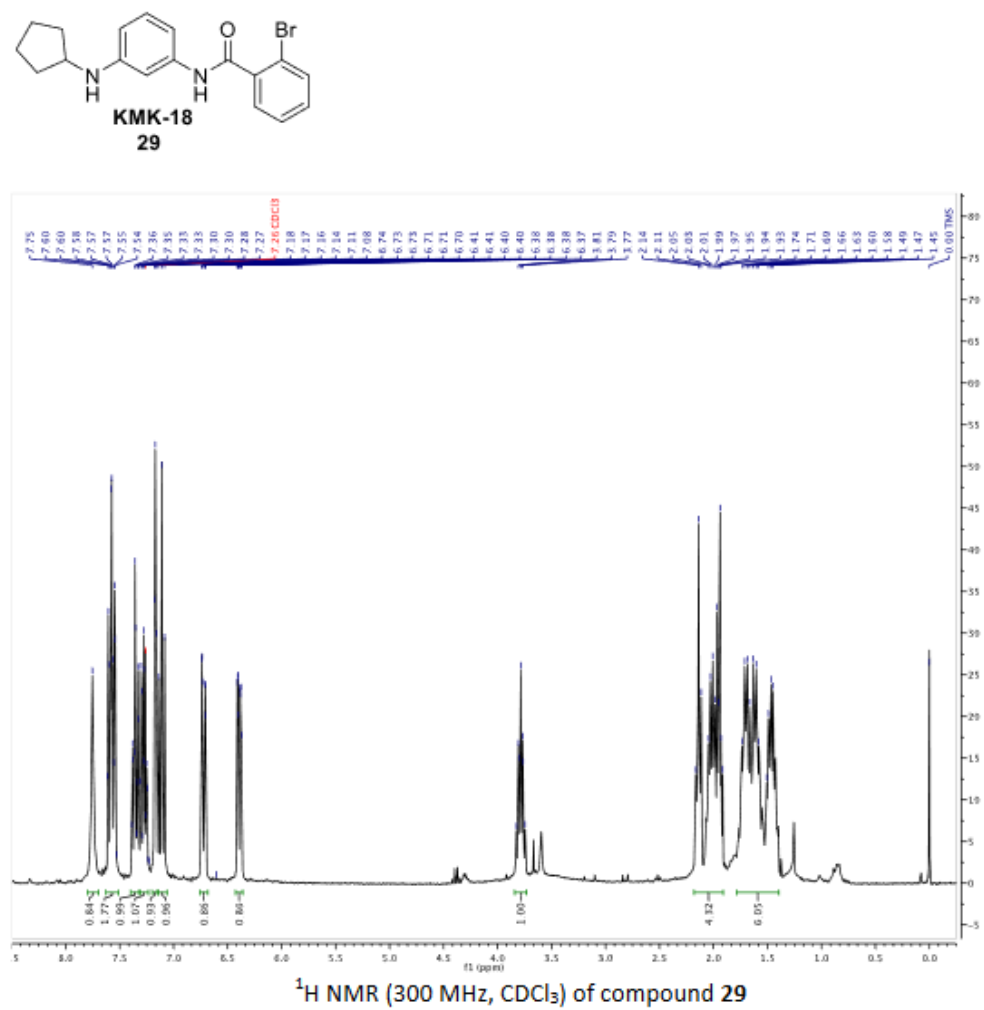

${ }^{1} \mathrm{H}$ NMR (300 MHz, $\mathrm{CDCl}_{3}$ ) of compound 29
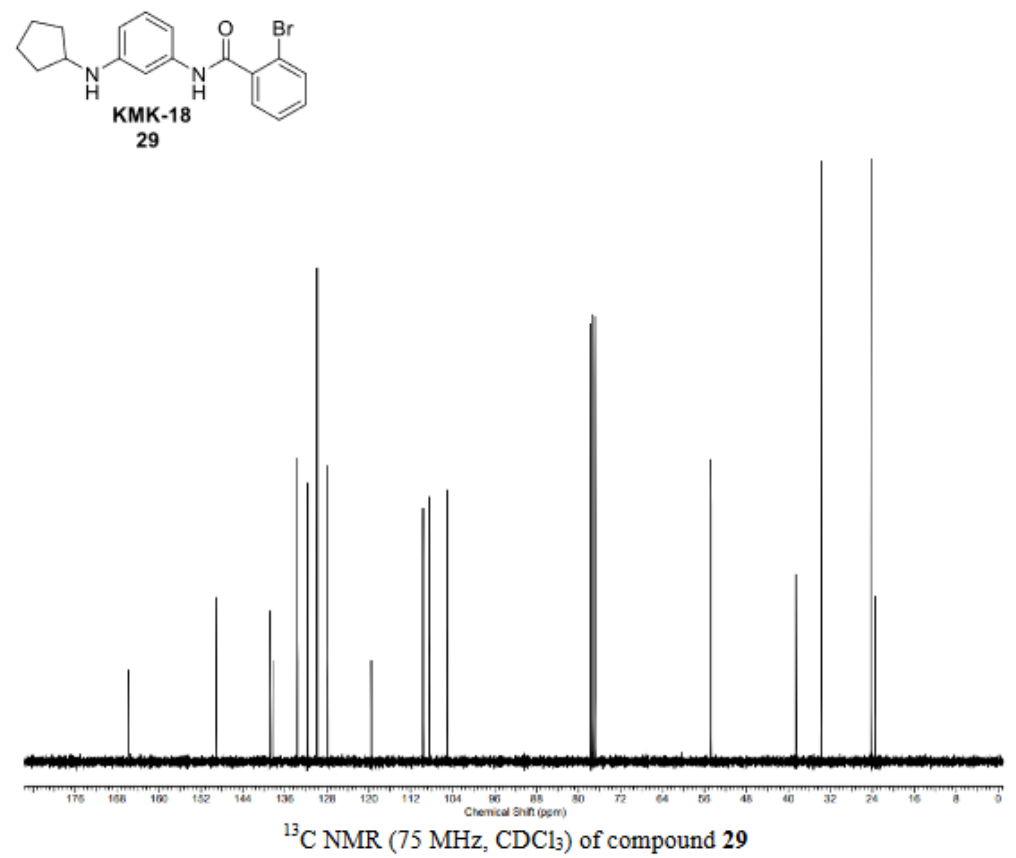

${ }^{13} \mathrm{C}$ NMR (75 MHz, $\mathrm{CDCl}_{3}$ ) of compound 29 


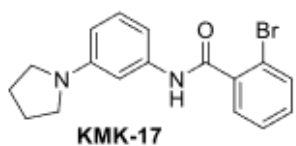

30

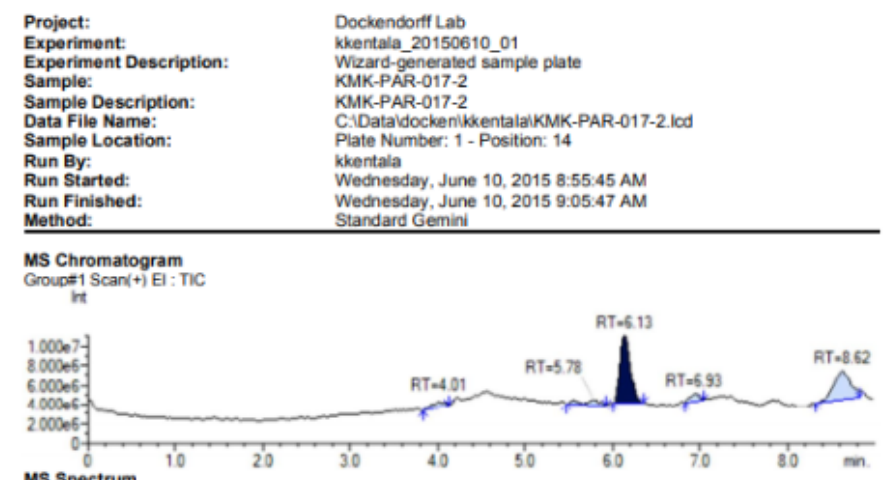

MS Spectrum
Grouple1- MS Peak: 3, RT: 6 to 6.34 min

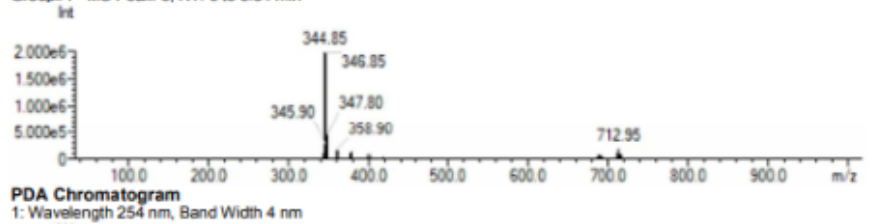

1: Wavelength $254 \mathrm{~nm}$, Band Width $4 \mathrm{~nm}$

mAU

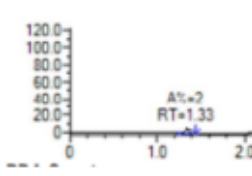

$\begin{array}{cccc}10 & 20 & 30 & 40 \\ \text { LC/MS (+ mode) for compound } 30\end{array}$

LC/MS (+ mode) for compound $\mathbf{3 0}$

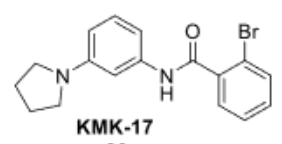

30

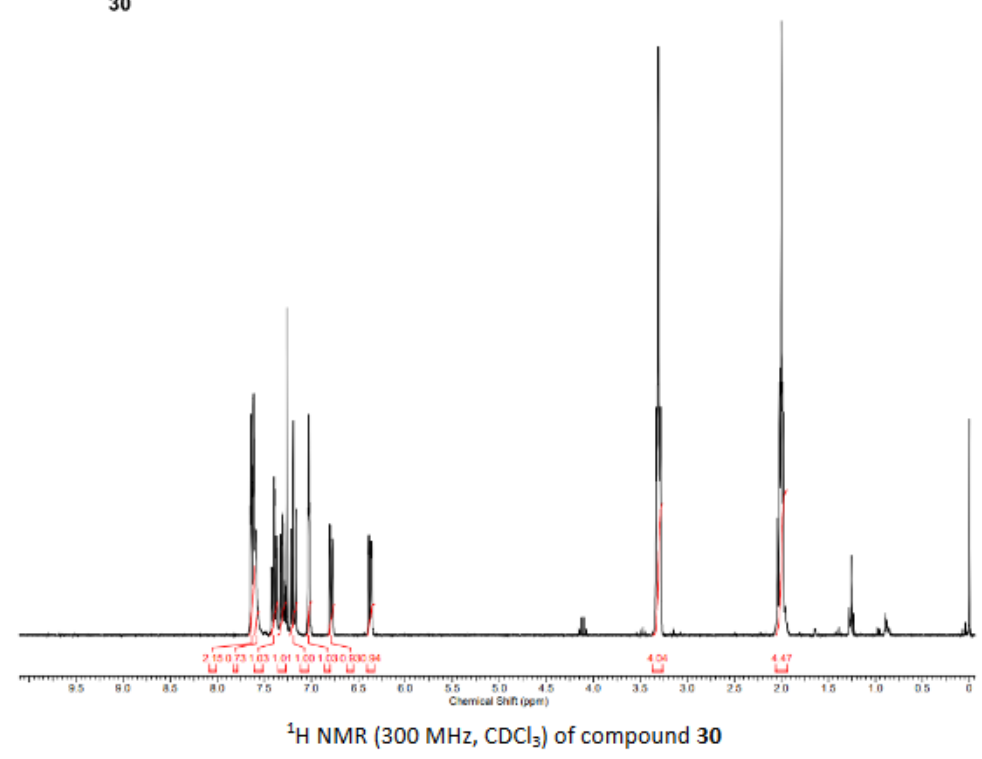

${ }^{1} \mathrm{H}$ NMR (300 MHz, $\mathrm{CDCl}_{3}$ ) of compound 30 


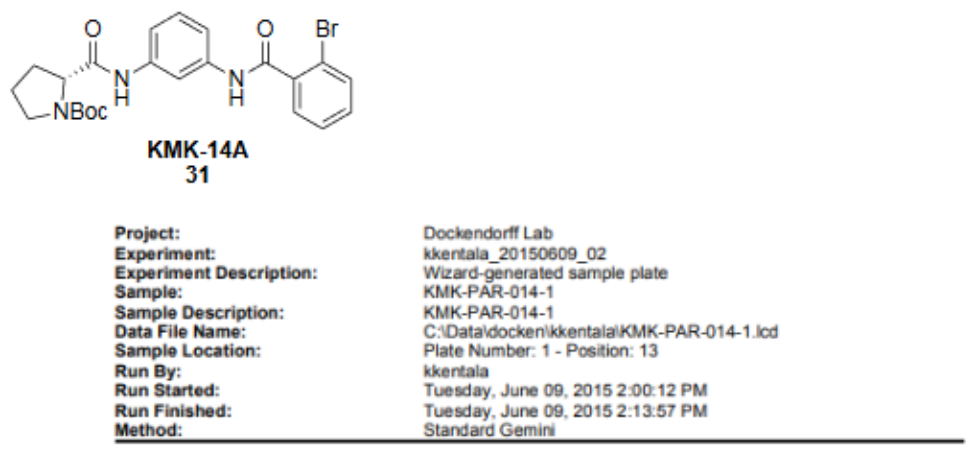

MS Chromatogram
Grouof2 Scan(-) El : TIC

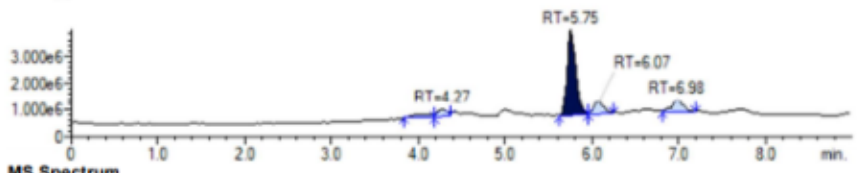

MS Spectrum

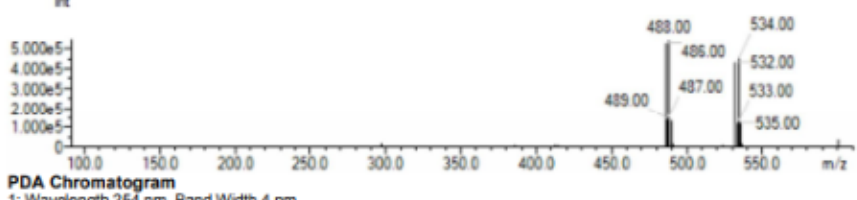

PDA Chromatogram
1: Wavelength $254 \mathrm{~nm}$ Band Width $4 \mathrm{~nm}$

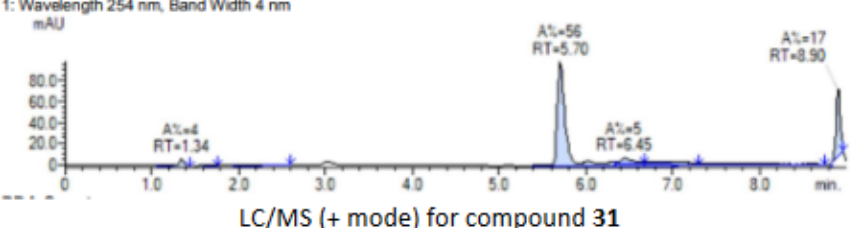

LC/MS (+ mode) for compound 31

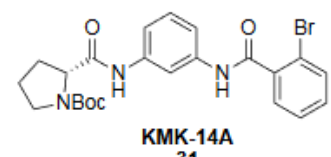

31

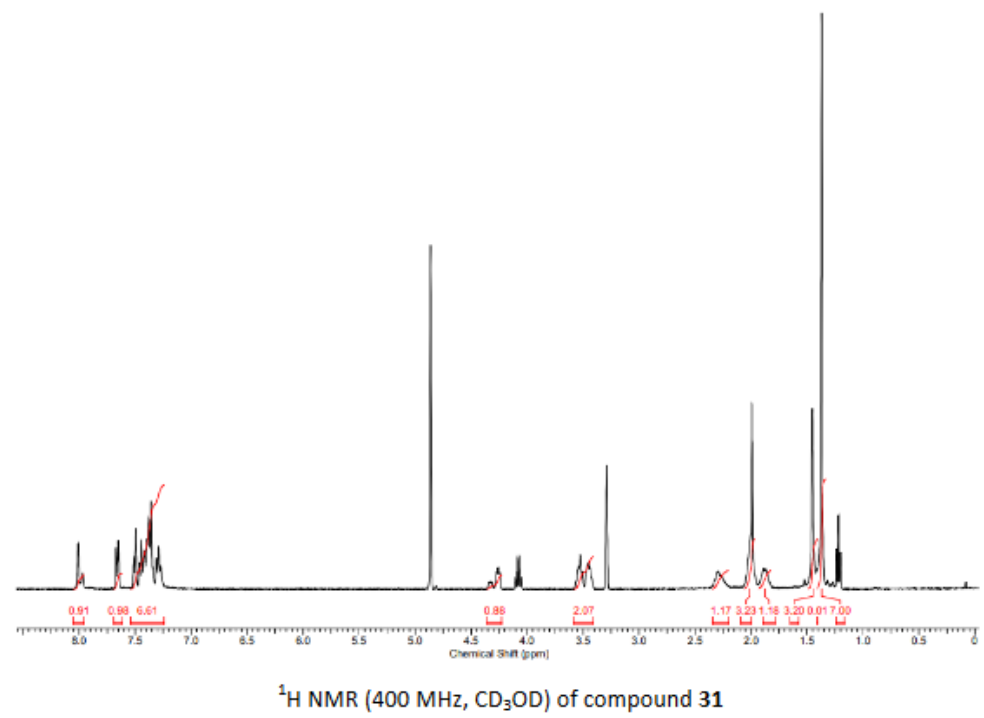

${ }^{1} \mathrm{H}$ NMR (400 MHz, CD ${ }_{3} \mathrm{OD}$ ) of compound 31 


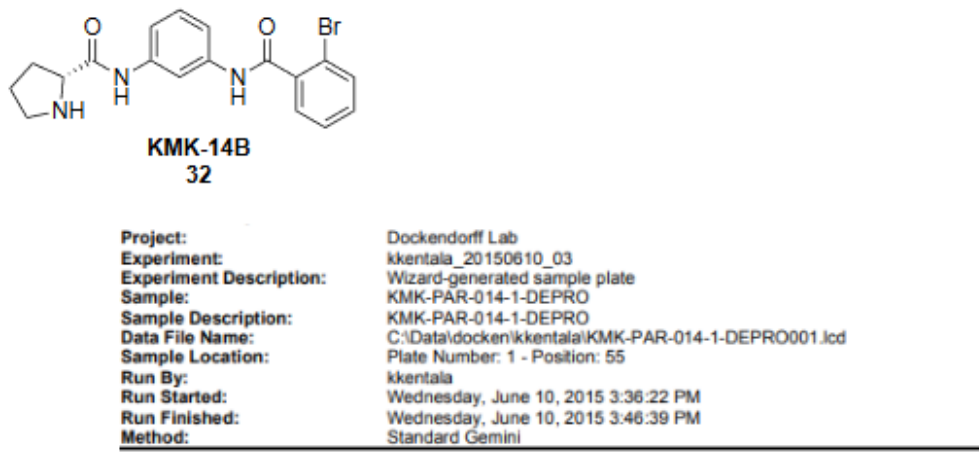

MS Chromatogram

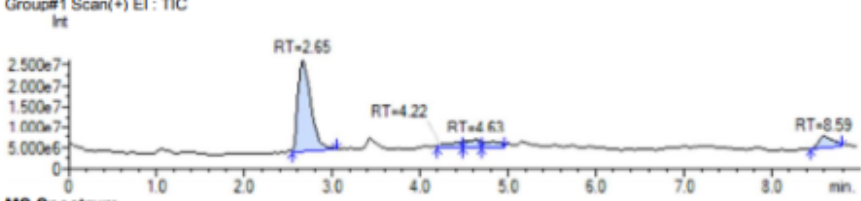

MS Spectrum
Groupin - PDA Peak: 11, RT: 2.41 to $3.63 \mathrm{~min}$

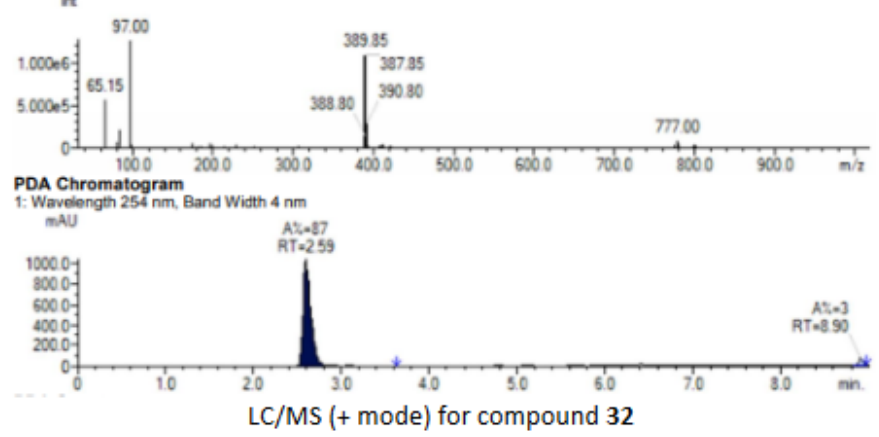

LC/MS (+ mode) for compound 32

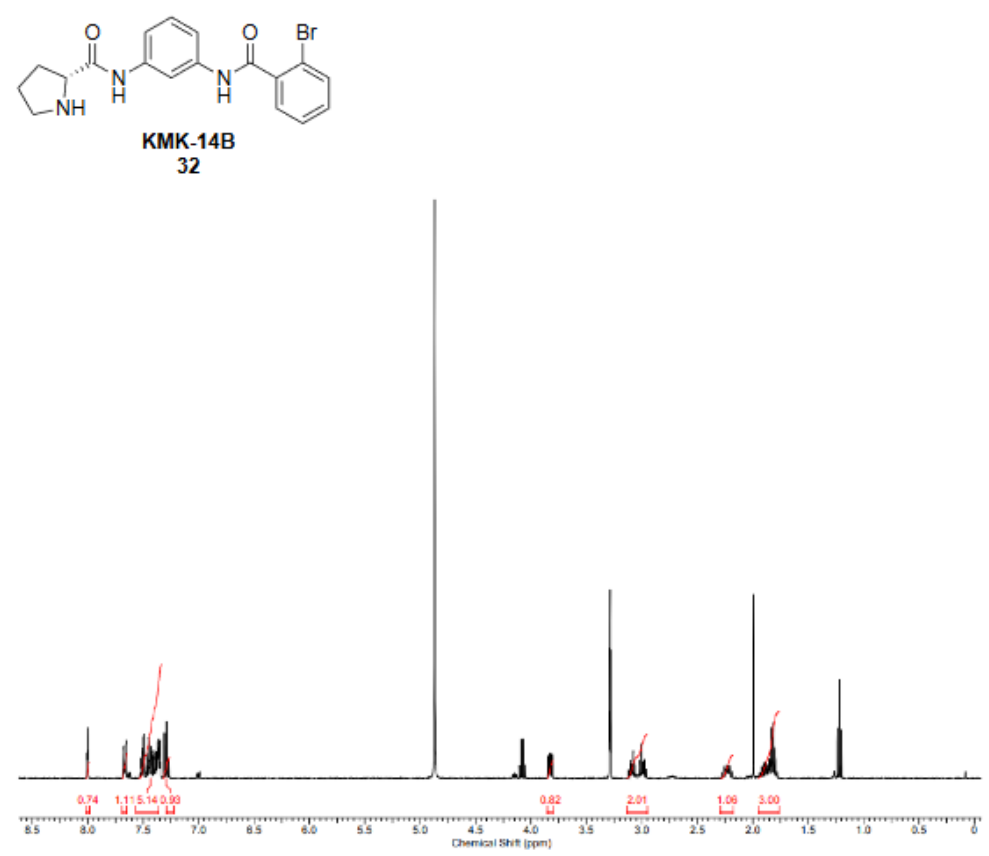

${ }^{1} \mathrm{H}$ NMR (400 MHz, CD ${ }_{3} \mathrm{OD}$ ) of compound 32

${ }^{1} \mathrm{H}$ NMR (400 MHz, CD ${ }_{3} \mathrm{OD}$ ) of compound 32 


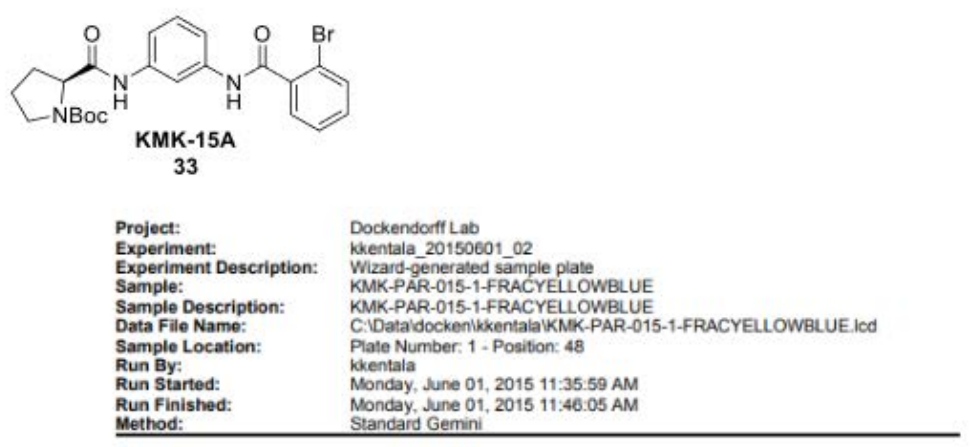

MS Chromatogram
Groupt2 Scan $(-)$ EI - TiC

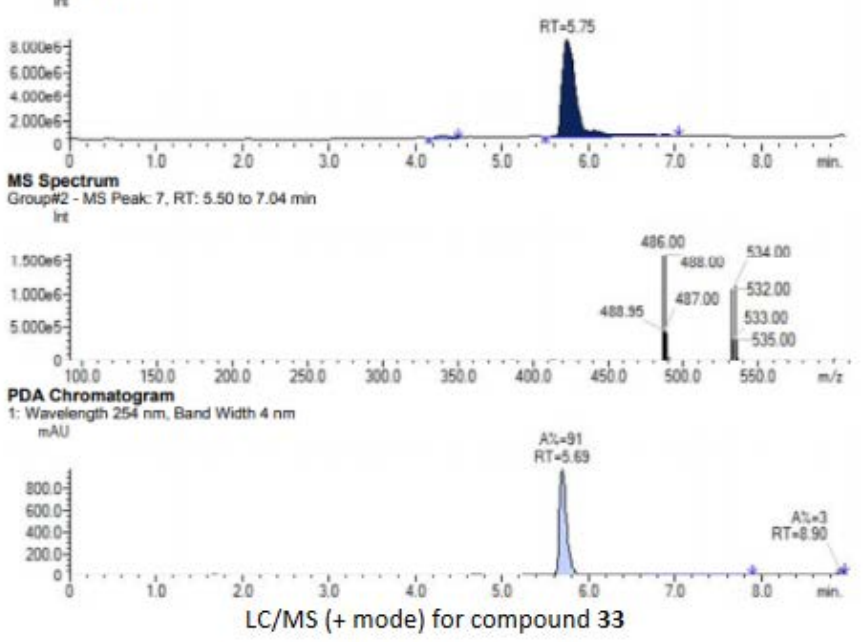

LC/MS (+ mode) for compound $\mathbf{3 3}$

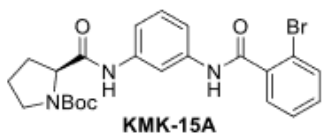

33

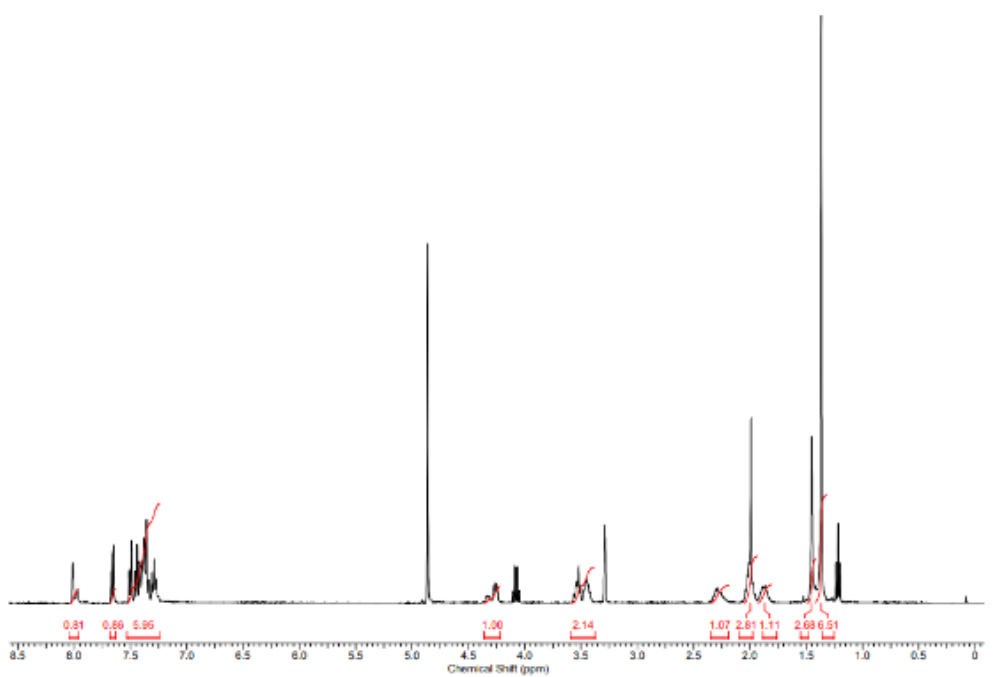

${ }^{1} \mathrm{H}$ NMR (400 MHz, CD 30 ) of compound 33

${ }^{1} \mathrm{H}$ NMR (400 MHz, $\mathrm{CD}_{3} \mathrm{OD}$ ) of compound 33 


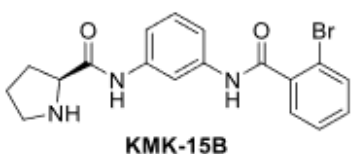

KMK-15B

34

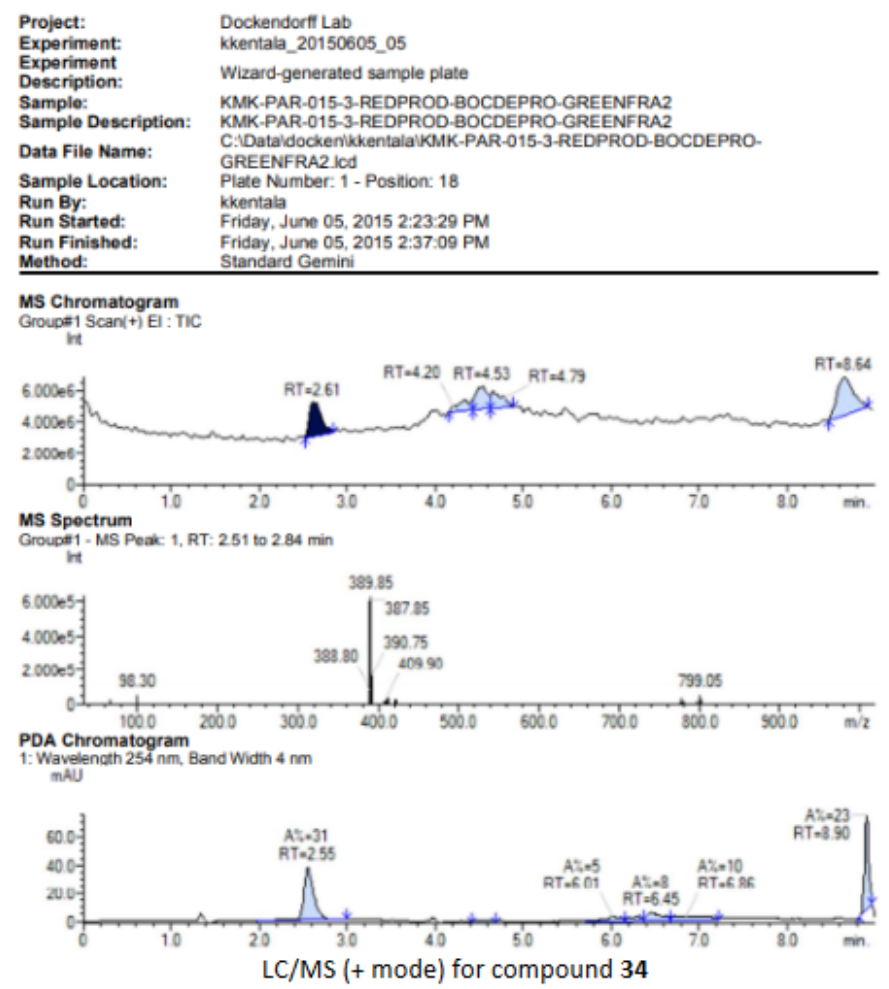

LC/MS (+ mode) for compound 34

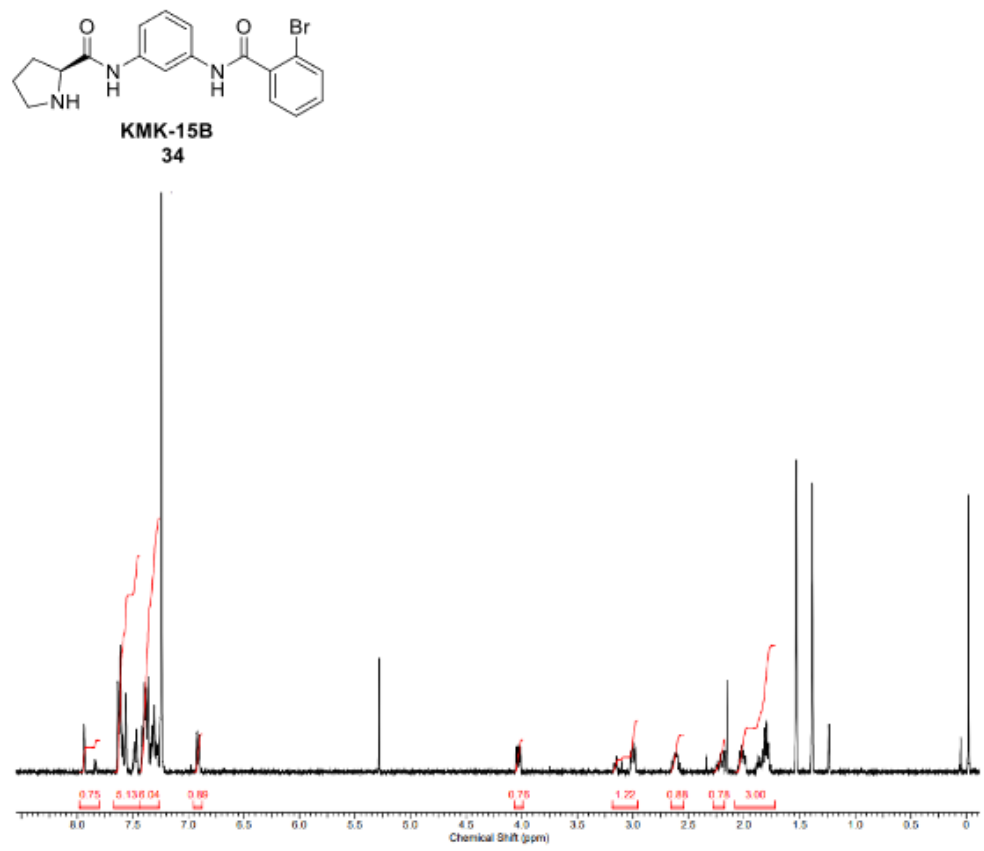

${ }^{1} \mathrm{H} \mathrm{NMR}\left(300 \mathrm{MHz}, \mathrm{CDCl}_{3}\right.$ ) of compound $\mathbf{3 4}$

${ }^{1} \mathrm{H} \mathrm{NMR}\left(300 \mathrm{MHz}, \mathrm{CDCl}_{3}\right.$ ) of compound 34 

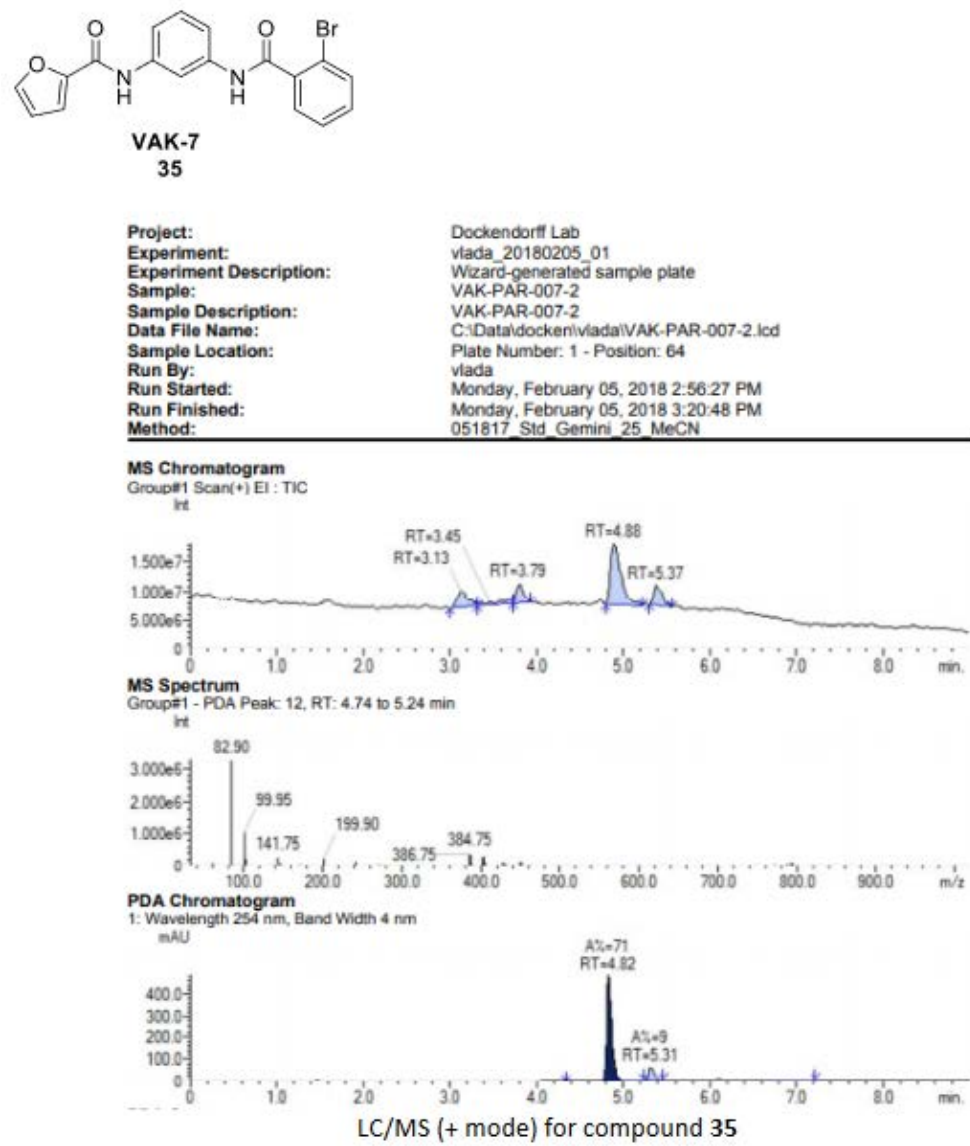

LC/MS (+ mode) for compound $\mathbf{3 5}$

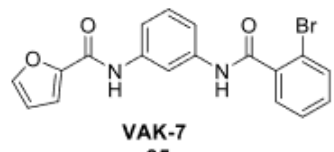

35

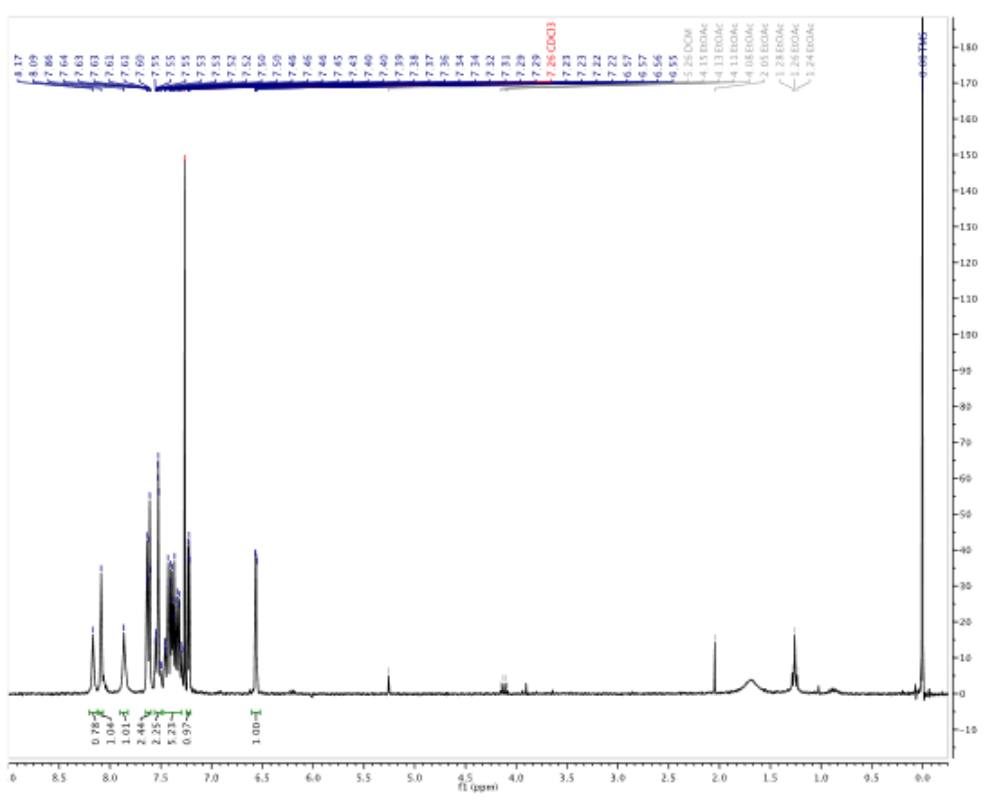

${ }^{1} \mathrm{H}$ NMR (300 MHz, $\mathrm{CDCl}_{3}$ ) of compound 35

${ }^{1} \mathrm{H}$ NMR (300 MHz, $\mathrm{CDCl}_{3}$ ) of compound 35 

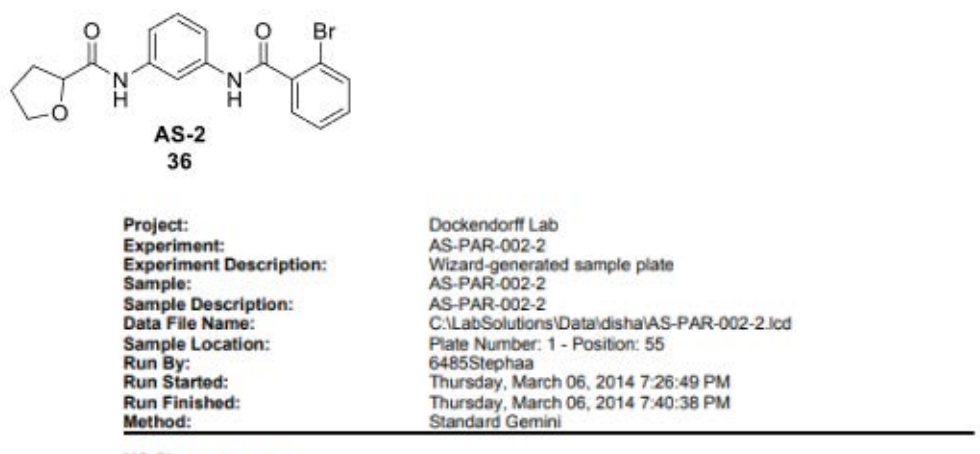

MS Chromatogram

Grouptit 1 Scan(+) El: TIC
int

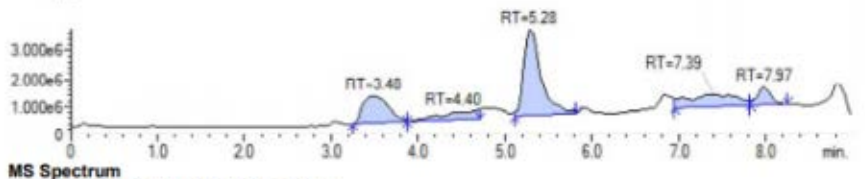

Mroupt1 - PDA Peak: 14, RT: 4.95 to 8.97 min

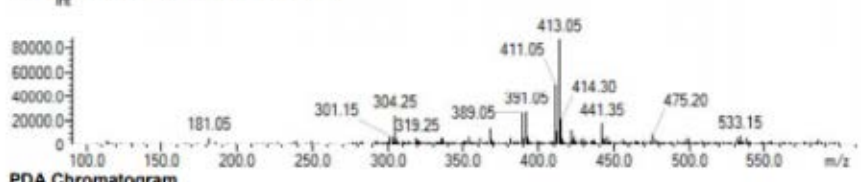

PDA Chromatogram, Band Width $4 \mathrm{~nm}$

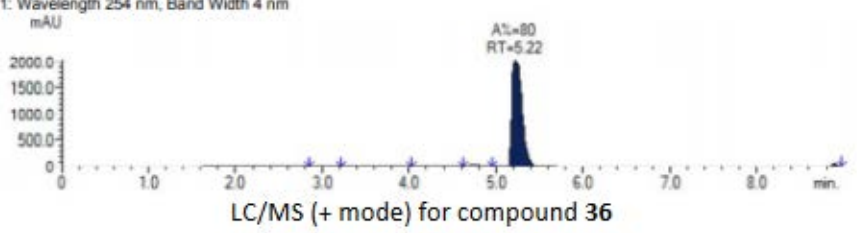

LC/MS (+ mode) for compound 36
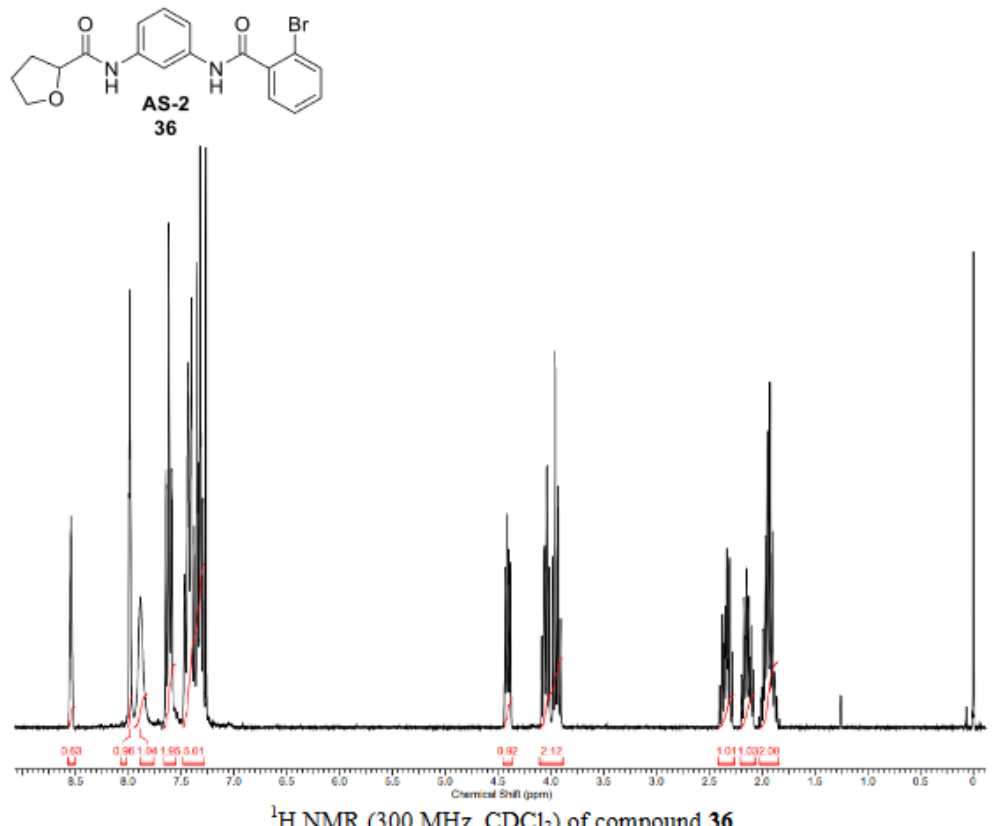

${ }^{1} \mathrm{H}$ NMR $\left(300 \mathrm{MHz}, \mathrm{CDCl}_{3}\right)$ of compound $\mathbf{3 6}$

${ }^{1} \mathrm{H}$ NMR (300 MHz, $\mathrm{CDCl}_{3}$ ) of compound 36 


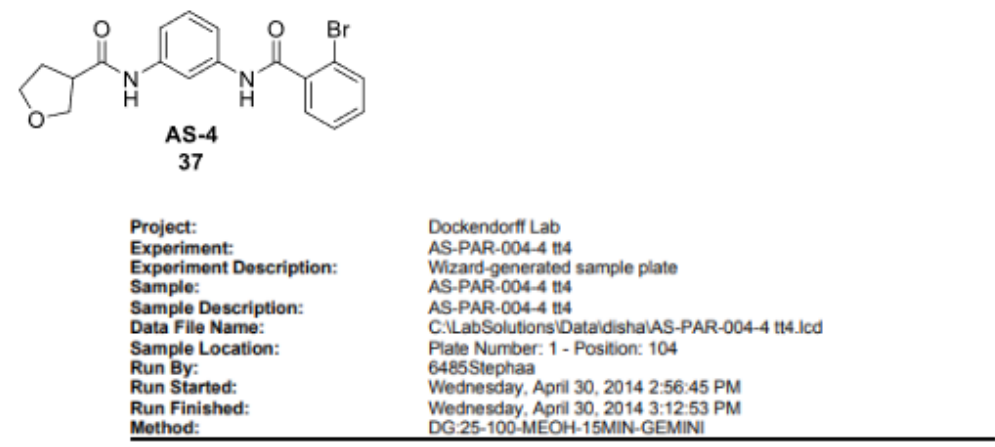

MS Chromatogram

Group:1 Scan(-) El : TiC

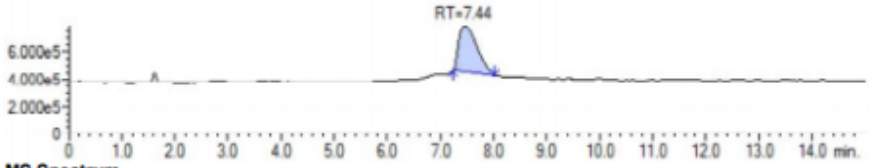

MS Spectrum
Group 1 - PDA Peak: 10, RT: 7.16 to $8.80 \mathrm{~min}$

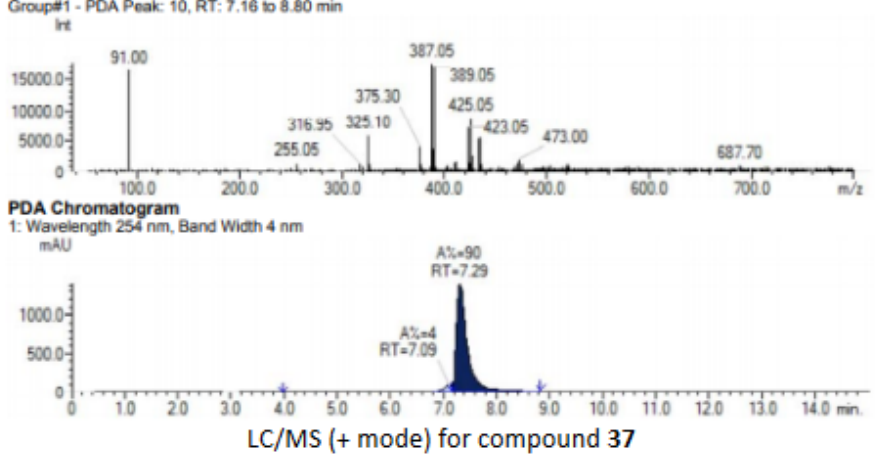

LC/MS (+ mode) for compound 37
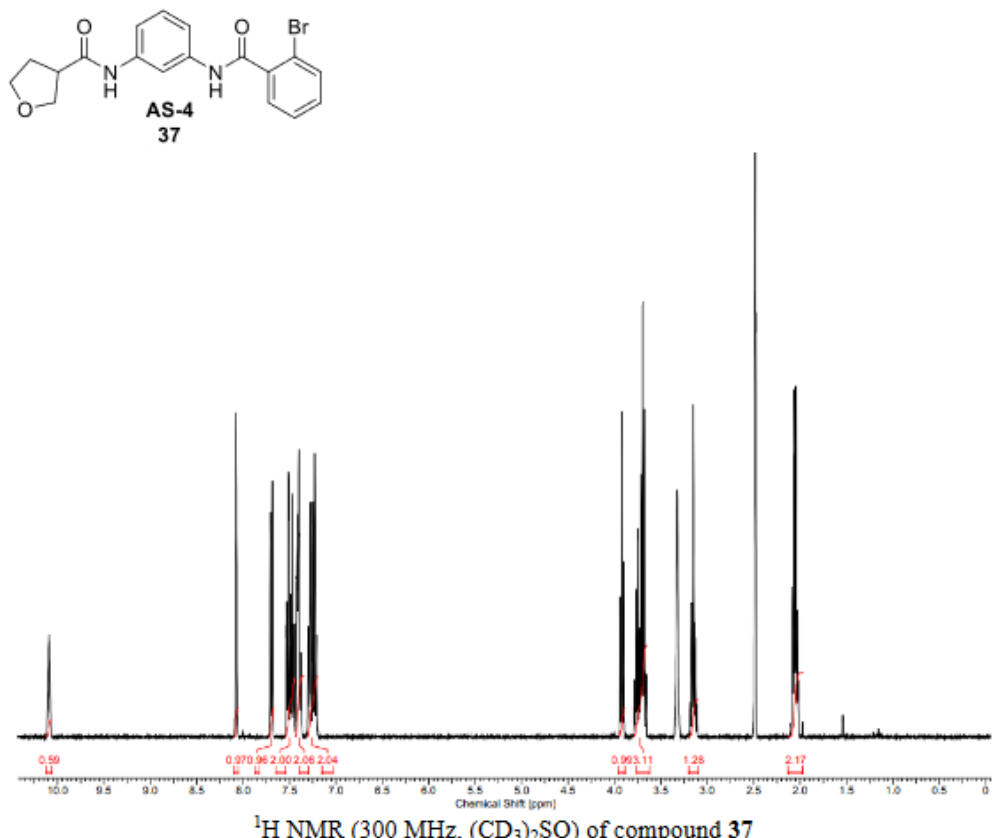

${ }^{1} \mathrm{H}$ NMR $\left(300 \mathrm{MHz},\left(\mathrm{CD}_{3}\right)_{2} \mathrm{SO}\right)$ of compound 37

${ }^{1} \mathrm{H}$ NMR (300 MHz, $\left.\left(\mathrm{CD}_{3}\right)_{2} \mathrm{SO}\right)$ of compound 37 


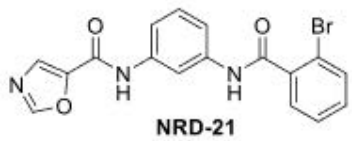

38
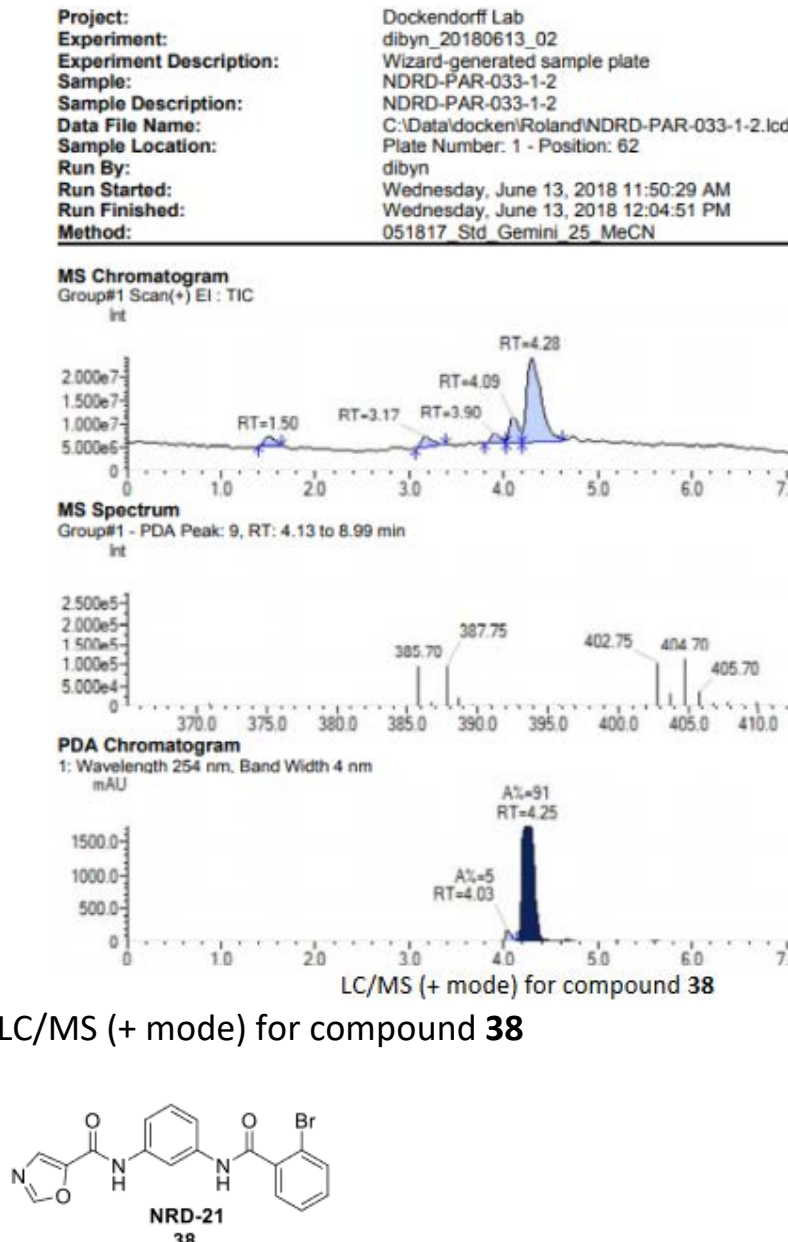

38

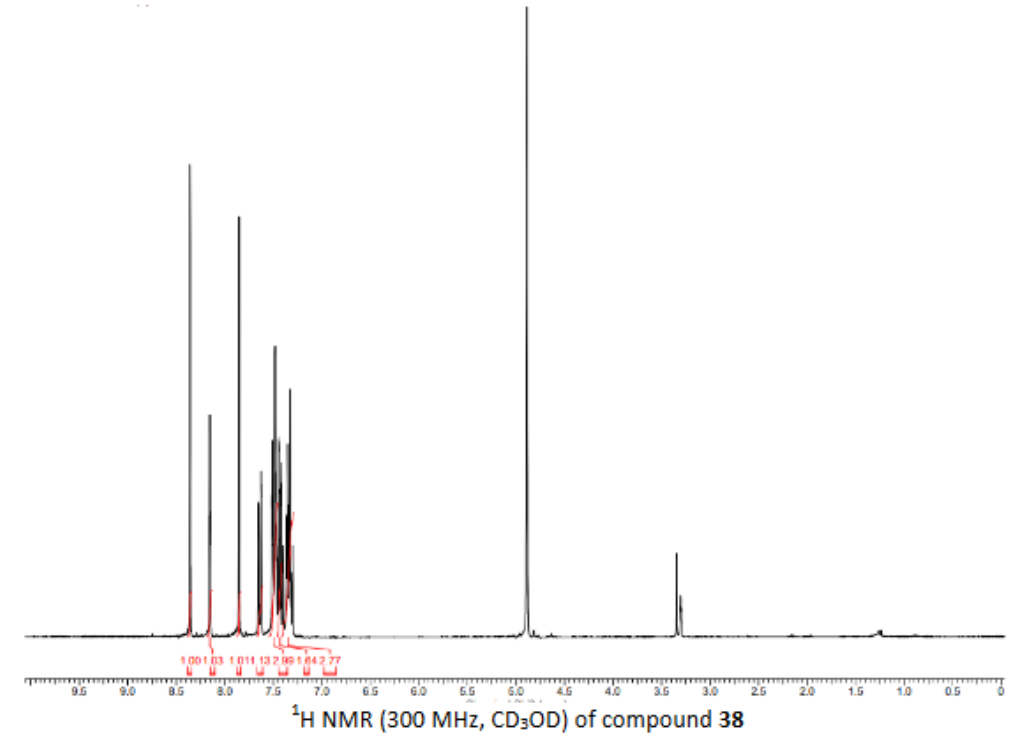

${ }^{1} \mathrm{H}$ NMR (300 MHz, CD ${ }_{3} \mathrm{OD}$ ) of compound 38 


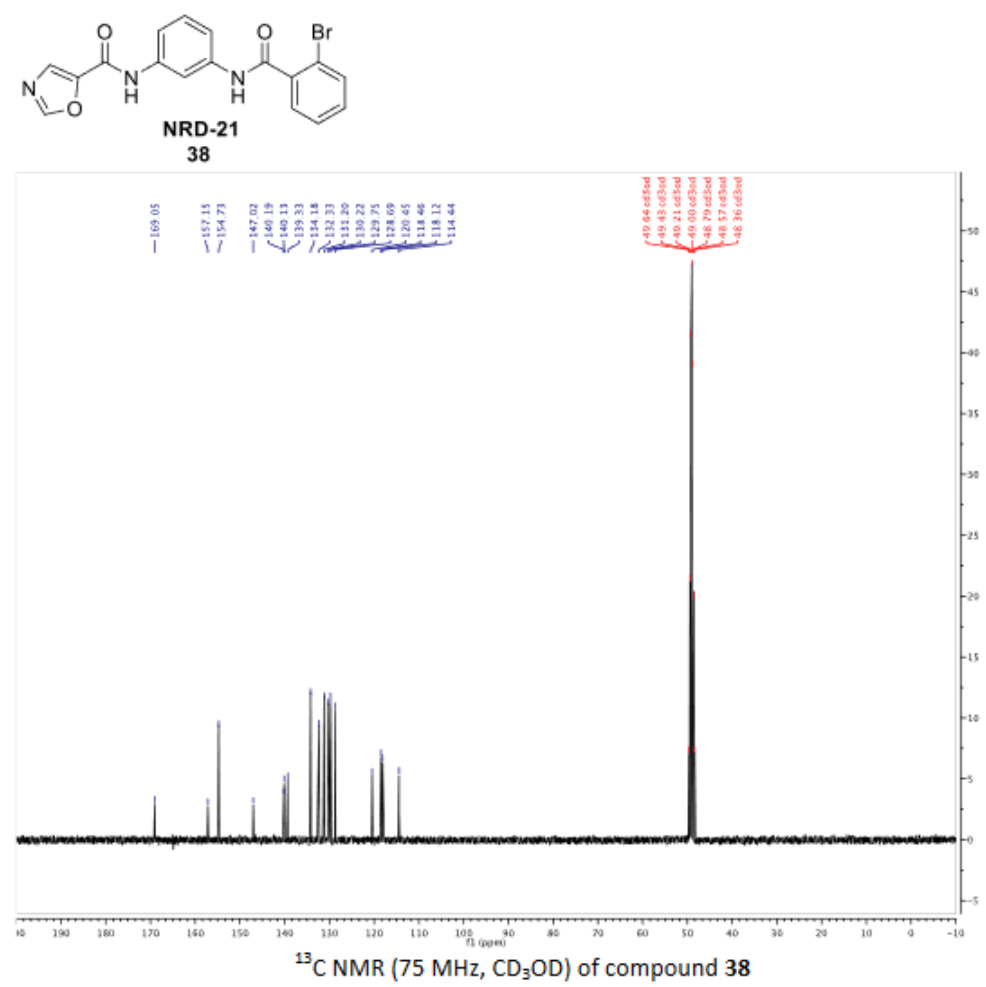

${ }^{13} \mathrm{C}$ NMR (75 MHz, CD $3 \mathrm{OD}$ ) of compound 38

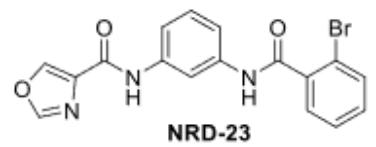

39

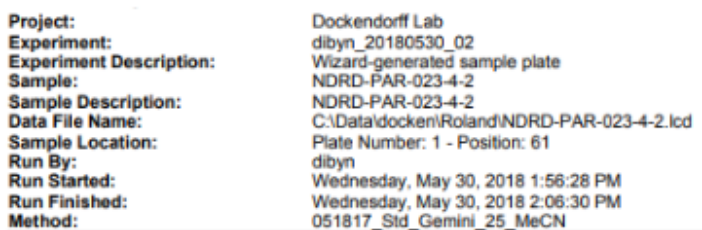

MS Chromatogram

Groupt+1 Scan(+) El: TIC

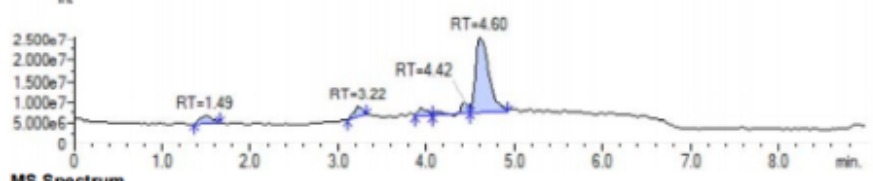

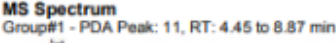

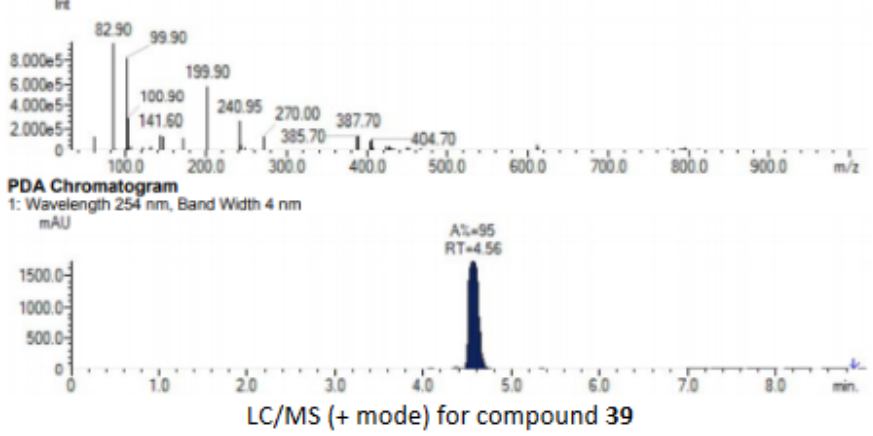

LC/MS (+ mode) for compound 39 


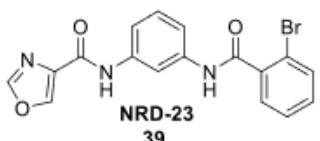

39

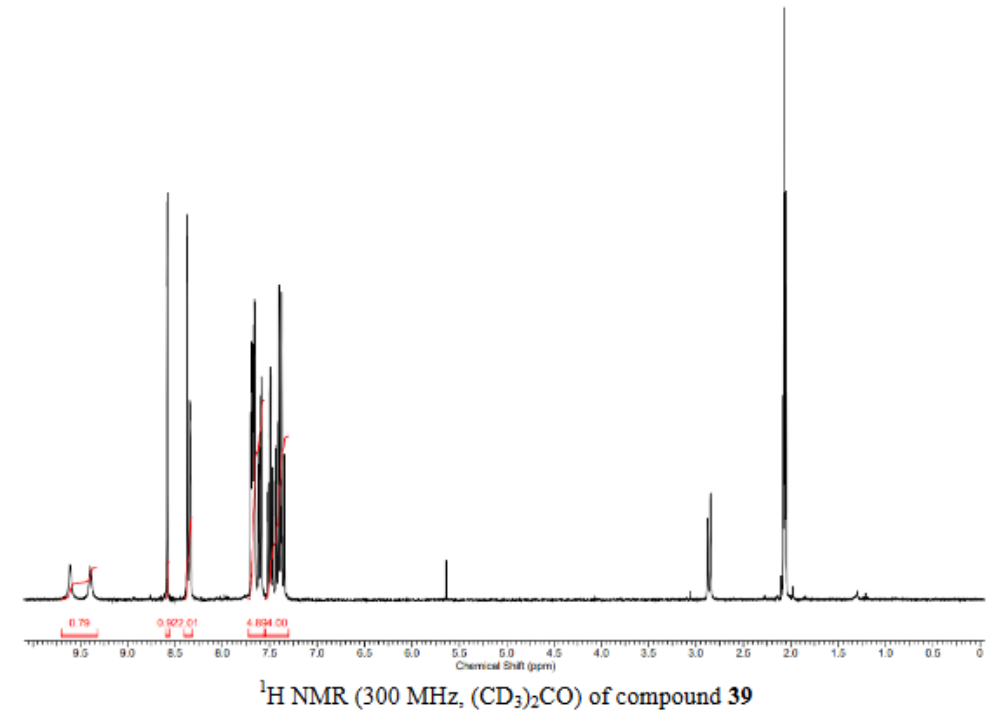

${ }^{1} \mathrm{H}$ NMR (300 MHz, $\left(\mathrm{CD}_{3}\right) 2 \mathrm{CO}$ ) of compound 39

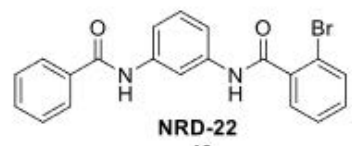

40

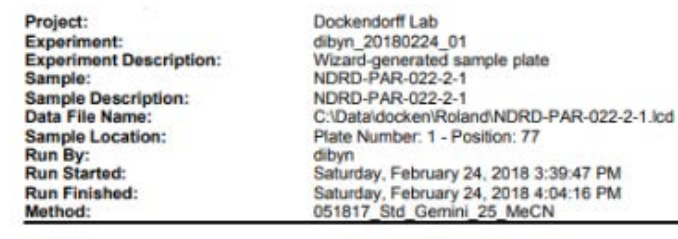

MS Chromatogram

Group:1 Scanit+) El : TIC

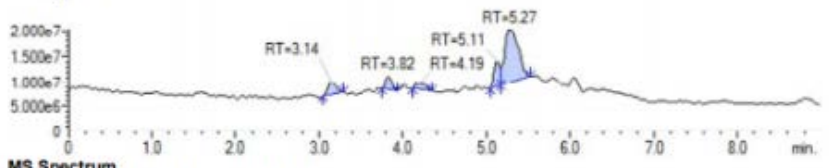

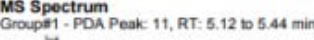

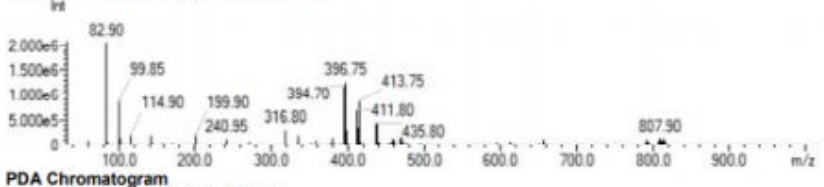
PDA Chromatogram
1: Wavelength $254 \mathrm{~nm}$, Band Width $4 \mathrm{~nm}$

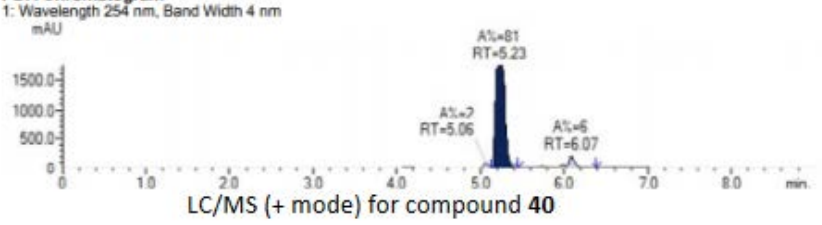

LC/MS (+ mode) for compound $\mathbf{4 0}$ 

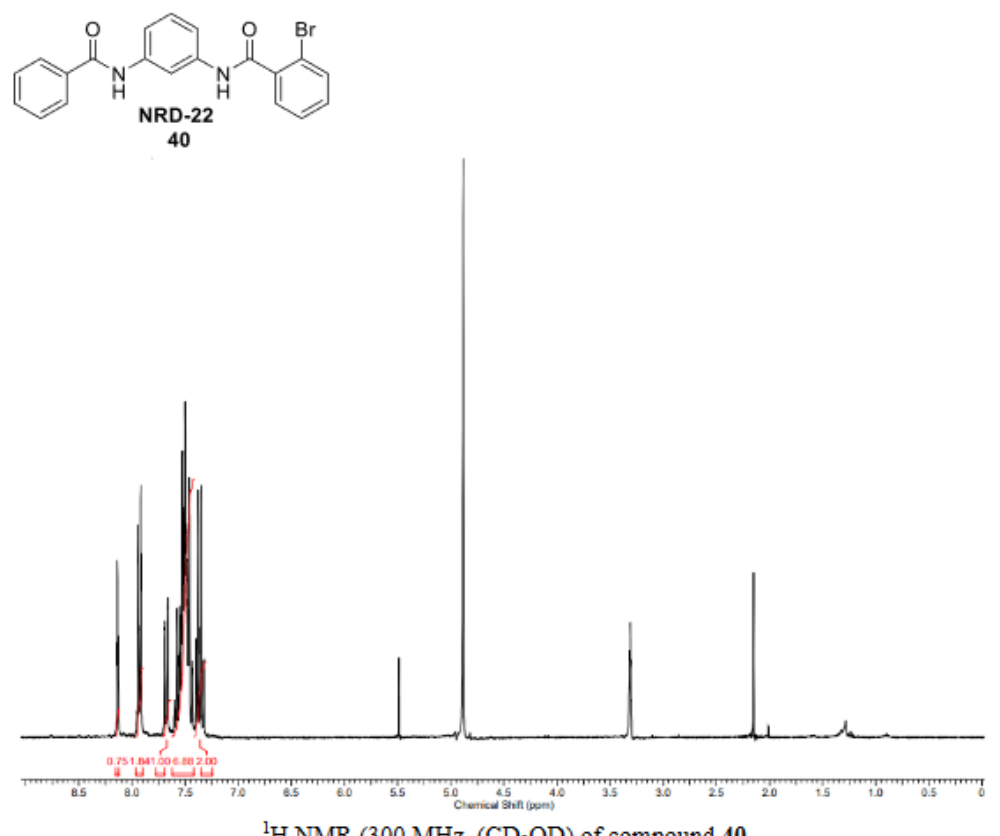

${ }^{1} \mathrm{H}$ NMR $\left(300 \mathrm{MHz},\left(\mathrm{CD}_{3} \mathrm{OD}\right)\right.$ of compound 40

${ }^{1} \mathrm{H}$ NMR $\left(300 \mathrm{MHz},\left(\mathrm{CD}_{3} \mathrm{OD}\right)\right.$ of compound 40

\section{References}

1. Gandhi, D. M.; Majewski, M. W.; Rosas Jr., R.; Kentala, K.; Foster, T. J.; Greve, E; Dockendorff, C. Bioorg. Med. Chem. 2018, 9, 2514-2529.

2. Dockendorff, C.; Aisiku, O.; Verplank, L., Dilks, J. R.; Smith, D. A.; Gunnink, S. F.; Dowal, L.; Negri, J.; Palmer, M.; Macpherson, L.; Schreiber, S. L.; Flaumenhaft, R. ACS Med. Chem. Lett. 2012, 3, 232-237.

\section{References}

1 J. Chen, M. Ishii, L. Wang, K. Ishii, S.R. Coughlin Thrombin Receptor Activation. Confirmation of the Intramolecular Tethered Liganding Hypothesis and Discovery of an Alternative Intermolecular Liganding Mode J Biol Chem, 269 (1994), pp. 16041-16045

2 M.N. Adams, R. Ramachandran, M.-K. Yau, et al. Structure, Function and Pathophysiology of Protease Activated Receptors Pharmacol Ther, 130 (2011), pp. 248-282

$\underline{3}$ R. Ramachandran, F. Noorbakhsh, K. DeFea, M.D. Hollenberg Targeting Proteinase-Activated Receptors:

Therapeutic Potential and Challenges Nat Rev Drug Discov, 11 (2012), pp. 69-86

4 M.D. Hollenberg, K. Mihara, D. Polley, et al. Biased Signalling and Proteinase-Activated Receptors (PARs): Targeting Inflammatory Disease Br J Pharmacol, 171 (2014), pp. 1180-1194

$\underline{5}$ U.J. Soh, J. Trejo Activated Protein C Promotes Protease-Activated Receptor-1 Cytoprotective Signaling

Through B-Arrestin and Dishevelled-2 Scaffolds Proc Natl Acad Sci USA, 108 (2011), pp. E1372-E1380

$\underline{6}$ T. Madhusudhan, H. Wang, B.K. Straub, et al. Cytoprotective Signaling by Activated Protein C Requires

Protease-Activated Receptor-3 in Podocytes Blood, 119 (2012), pp. 874-883

7 R.A. Schuepbach, J. Madon, M. Ender, P. Galli, M. Riewald Protease-Activated Receptor-1 Cleaved at R46

Mediates Cytoprotective Effects J Thromb Haemost, 10 (2012), pp. 1675-1684

8 L.O. Mosnier, R.K. Sinha, L. Burnier, E.A. Bouwens, J.H. Griffin Biased Agonism of Protease-Activated Receptor

1 by Activated Protein C Caused by Noncanonical Cleavage at Arg46 Blood, 120 (2012), pp. 5237-5246

9 E. Bouwens, F. Stavenuiter, L.O. Mosnier Mechanisms of Anticoagulant and Cytoprotective Actions of the

Protein C Pathway J Thromb Haemost, 11 (2013), pp. 242-253

10 L. Burnier, L.O. Mosnier Novel Mechanisms for Activated Protein C Cytoprotective Activities Involving Noncanonical Activation of Protease-Activated Receptor 3 Blood, 122 (2013), pp. 807-816 
11 U.B. Rasmussen, C. Gachet, Y. Schlesinger, et al. A Peptide Ligand of the Human Thrombin Receptor Antagonizes Alpha-Thrombin and Partially Activates Platelets J Biol Chem, 268 (1993), pp. 1432214328

12 R. Ramachandran, K. Mihara, M. Mathur, et al. Agonist-Biased Signaling via Proteinase Activated Receptor2: Differential Activation of Calcium and Mitogen-Activated Protein Kinase Pathways Mol Pharmacol, 76 (2009), pp. 791-801

13 G.D. Barry, J.Y. Suen, G.T. Le, A. Cotterell, R.C. Reid, D.P. Fairlie Novel Agonists and Antagonists for Human Protease Activated Receptor 2 J Med Chem, 53 (2010), pp. 7428-7440

14 J.Y. Suen, G.D. Barry, R.J. Lohman, et al. Modulating Human Proteinase Activated Receptor 2 with a Novel Antagonist (GB88) and Agonist (GB110) Br J Pharmacol, 165 (2012), pp. 1413-1423

15 L. Covic, A.L. Gresser, J. Talavera, S. Swift, A. Kuliopulos Activation and Inhibition of G Protein-Coupled Receptors by Cell-Penetrating Membrane-Tethered Peptides Proc Natl Acad Sci USA, 99 (2002), pp. 643-648

16 Carlson KE, McMurry TJ, Hunt SW III. Pepducins: Lipopeptide Allosteric Modulators of GPCR Signaling. Drug Discovery Today: Technol 2012;9:e33-e39.

17 P. Zhang, A.J. Leger, J.D. Baleja, et al. Allosteric Activation of a G Protein-Coupled Receptor with CellPenetrating Receptor Mimetics J Biol Chem, 290 (2015), pp. 15785-15798

18 L.M. Sevigny, P. Zhang, A. Bohm, et al. Interdicting Protease-Activated Receptor-2-Driven Inflammation with Cell-Penetrating Pepducins Proc Natl Acad Sci, 108 (2011), pp. 8491-8496

19 L. Dowal, D.S. Sim, J.R. Dilks, et al. Identification of an Antithrombotic Allosteric Modulator That Acts Through Helix 8 of PAR1 Proc Natl Acad Sci, 108 (2011), pp. 2951-2956

20 C. Dockendorff, O. Aisiku, L. Verplank, et al. Discovery of 1,3-Diaminobenzenes as Selective Inhibitors of Platelet Activation at the PAR1 Receptor ACS Med Chem Lett, 3 (2012), pp. 232-237

21 O. Aisiku, C.G. Peters, K. De Ceunynck, et al. Parmodulins Inhibit Thrombus Formation Without Inducing Endothelial Injury Caused by Vorapaxar Blood, 125 (2015), pp. 1976-1985

$\underline{22}$ K. De Ceunynck, C.G. Peters, A. Jain, et al. PAR1 Agonists Stimulate APC-Like Endothelial Cytoprotection and Confer Resistance to Thromboinflammatory Injury Proc Natl Acad Sci, 115 (2018), pp. E982-E991

23 S. Nazir, I. Gadi, M.M. Al-Dabet, et al. Cytoprotective Activated Protein C Averts NIrp3 Inflammasome Induced Ischemia Reperfusion Injury via mTORC1 Inhibition Blood, 130 (2017), pp. 2664-2677

24 D.M. Gandhi, M.W. Majewski, R. Rosas, et al. Characterization of Protease-Activated Receptor (PAR) Ligands: Parmodulins Are Reversible Allosteric Inhibitors of PAR1-Driven Calcium Mobilization in Endothelial Cells Bioorg Med Chem, 26 (2018), pp. 2514-2529

25 L.O. Mosnier, J.H. Griffin Inhibition of Staurosporine-Induced Apoptosis of Endothelial Cells by Activated Protein C Requires Protease-Activated Receptor-1 and Endothelial Cell Protein C Receptor Biochem. J., 373 (2003), pp. 65-70

$\underline{26}$ L. Verplank, C. Dockendorff, J. Negri, et al. Chemical Genetic Analysis of Platelet Granule Secretion-Probe 3 National Center for Biotechnology Information (US): Bethesda (MD) (2010)

27 A.J. Chu Tissue Factor Mediates Inflammation Arch Biochem Biophys, 440 (2005), pp. 123-132

$\underline{28}$ M.P. Bevilacqua, J.S. Pober, G.R. Majeau, W. Fiers, R.S. Cotran, M.A. Gimbrone Recombinant Tumor Necrosis Factor Induces Procoagulant Activity in Cultured Human Vascular Endothelium: Characterization and Comparison with the Actions of Interleukin 1 Proc Natl Acad Sci USA, 83 (1986), pp. 4533-4537

29 P.P. Nawroth, D.M. Stern Modulation of Endothelial Cell Hemostatic Properties by Tumor Necrosis Factor J Exp Med, 163 (1986), pp. 740-745

30 M. Colucci, G. Balconi, R. Lorenzet, et al. Cultured Human Endothelial Cells Generate Tissue Factor in Response to Endotoxin J Clin Investig, 71 (1983), pp. 1893-1896

$\underline{31}$ S. Gando, M. Levi, C.-H. Toh Disseminated Intravascular Coagulation Nat Rev Dis Primers, 2 (2016), p. 16037

$\underline{32}$ J. Besnard, G.F. Ruda, V. Setola, et al. Automated Design of Ligands to Polypharmacological Profiles Nature, 492 (2012), pp. 215-220 
33 Gandhi D, Rosas R Jr, Greve E, et al. The Parmodulin NRD-21 Is an Allosteric Inhibitor of PAR1 Gq Signaling with Improved Anti-Inflammatory Activity and Stability. ChemRxiv (preprint) 2019.

https://doi.org/10.26434/chemrxiv.7755479.v1.

\section{Note}

${ }^{1}$ These authors contributed equally to this manuscript. 